\title{
Environmental Problems in the People's Republic of China: Current Magnitude and Possible Control Options
}

Decision and Information Sciences Division Argonne National Laboratory 


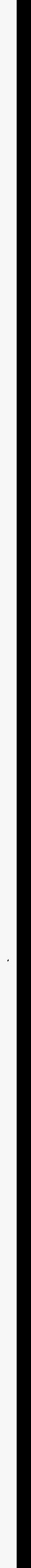




\section{Argonne National Laboratory}

Argonne National Laboratory, with facilities in the states of Illinois and Idaho, is owned by the United States Government, and operated by the University of Chicago under the provisions of a contract with the Department of Energy.

This technical memo is a product of Argonne's Decision and Information Sclences (DIS) Division. For information on the division's scientific and engineering activities, contact:

Director, Decision and Information

Sciences Division

Argonne National Laboratory

Argonne, Illinois 60439-4815

Telephone (708) 252-5464

Presented in this technical memo are preliminary results of ongoing work or work that is more limited in scope and depth than that described in formal reports issued by the DIS Division.

Publishing support services were provided by Argonne's Information and Publishing Division (for more information, see IPD's home page: http://www.jpd:anl.gov/).

\section{Disclaimer}

This report was prepared as an account of work sponsored by an agency of the United States Government. Neither the United States Government nor any agency thereof, nor any of their employees, makes any warranty, express or implied, or assumes any legal liability or responsibility for the accuracy, completeness, or usefulness of any information, apparatus, product, or process disclosed, or represents that its use would not infringe privately owned rights. Reference herein to any specific commercial product, process, or service by trade name, trademark, manufacturer, or otherwise, does not necessarily constitute or imply its endorsement, recommendation, or favoring by the United States Government or any agency thereof. The views and opinions of authors expressed herein do not necessarily state or reflect those of the United States Government or any agency thereof. 



\section{Environmental Problems in the People's Republic of China: Current Magnitude and Possible Control Options}

by N. Bhatti, C.A. Biang, ${ }^{*}$ L.A. Poch, and M.M. Tompkins

Decision and Information Sciences Division,

Argonne National Laboratory, 9700 South Cass Avenue, Argonne, Illinois 60439

September 1995

* Biang is affiliated with Argonne's Environmental Assessment Division. 
This report is printed on recycled paper. 


\section{CONTENTS}

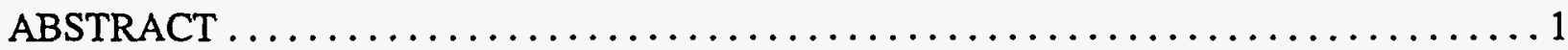

1 INTRODUCTION $\ldots \ldots \ldots \ldots \ldots \ldots \ldots \ldots \ldots \ldots \ldots \ldots \ldots \ldots \ldots \ldots \ldots \ldots \ldots \ldots$

2 ENVIRONMENTAL IMPACTS OF COAL USE, OTHER ENERGY USE, AND INDUSTRIAL ACTIVITIES IN CHINA $\ldots \ldots \ldots \ldots \ldots \ldots \ldots \ldots \ldots \ldots \ldots$

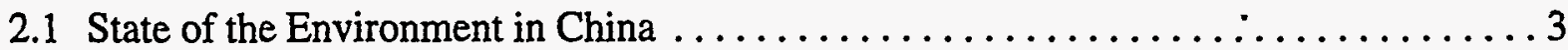

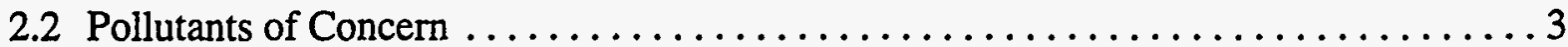

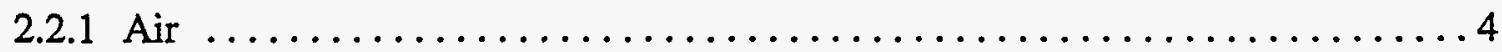

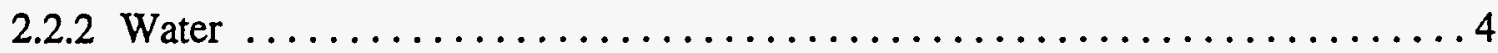

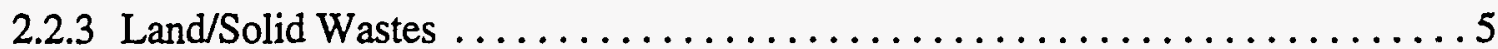

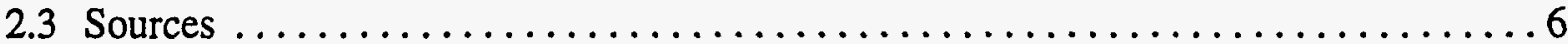

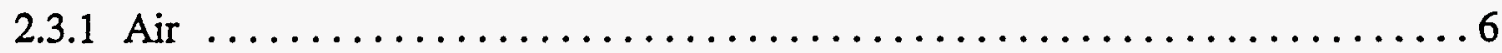

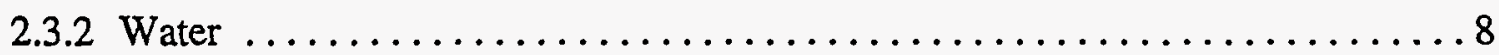

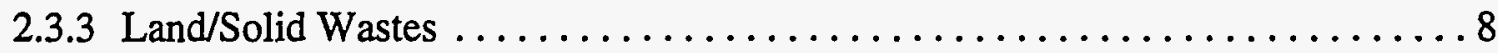

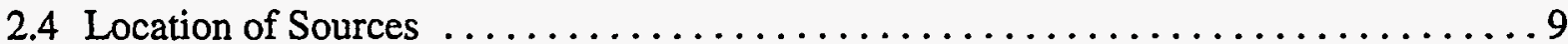

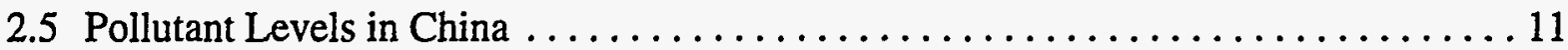

2.6 Sensitive Receptors and Potential Impacts $\ldots \ldots \ldots \ldots \ldots \ldots \ldots \ldots \ldots \ldots \ldots \ldots \ldots \ldots$

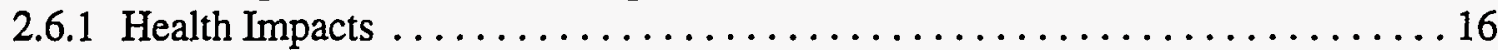

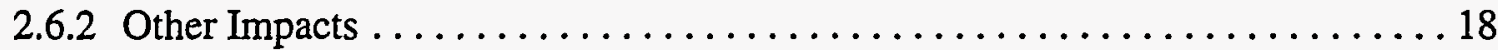

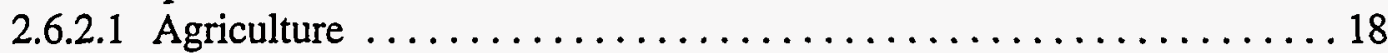

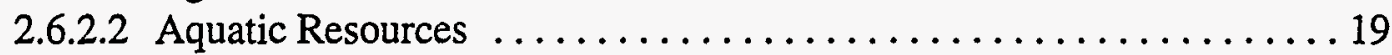

2.6.2.3 Marine Resources ............................. 20

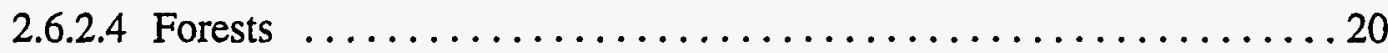

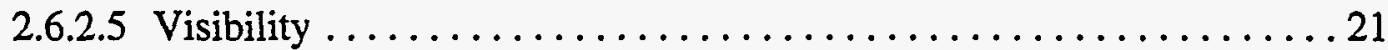

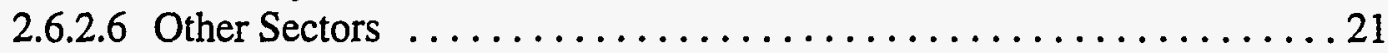

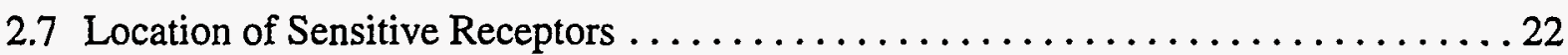

3 REGULATORY/AMELIORATIVE OPTIONS FOR CHINA $\ldots \ldots \ldots \ldots \ldots \ldots \ldots$

3.1 History of Environmental Regulations in China $\ldots \ldots \ldots \ldots \ldots \ldots \ldots \ldots .25$

3.2 Major Environmental Threats Currently Facing China $\ldots \ldots \ldots \ldots \ldots \ldots \ldots 27$

3.3 Early U.S. Experience in Addressing Pollution Problems $\ldots \ldots \ldots \ldots \ldots \ldots \ldots .28$

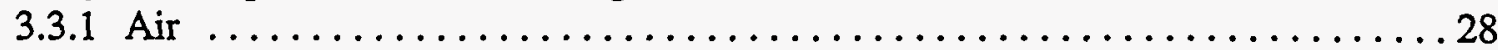

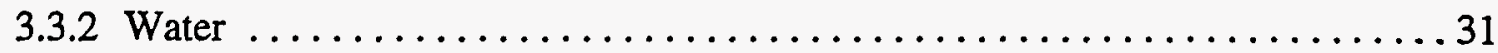

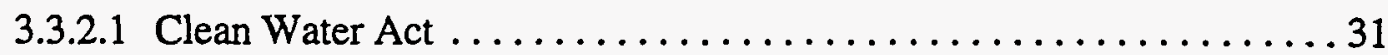

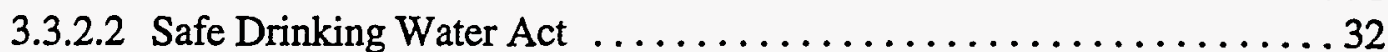

3.4 Possible Near-term Strategies to Address the Most Pressing Environmental Problems in China on the Basis of U.S. Experience $\ldots \ldots \ldots \ldots \ldots \ldots \ldots \ldots \ldots \ldots$

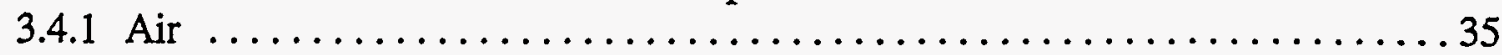




\section{CONTENTS (Cont.)}

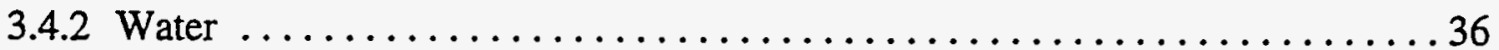

3.4.2.1 Potential Remedies for Urban Water Pollution .............. 37

3.4.2.2 Potential Remedies for Rural Water Pollution ............... 38

3.4.2.3 Conclusions ................................... 39

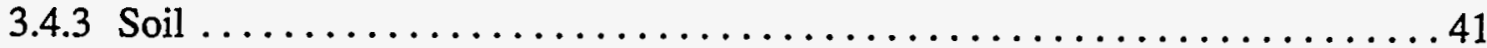

3.4.3.1 Potential Remedies for Chemically Contaminated Soil ......... 41

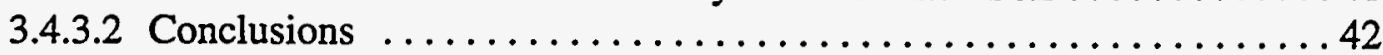

\section{TECHNICAL OPTIONS FOR CONTROLLING ENVIRONMENTAL}

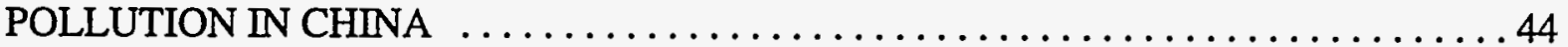

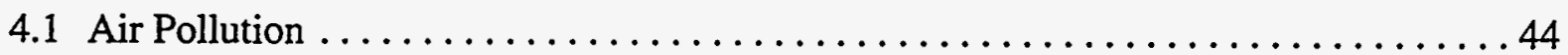

4.1.1 General Introduction and Background $\ldots \ldots \ldots \ldots \ldots \ldots \ldots \ldots \ldots \ldots 44$

4.1.2 Descriptions of Specific Technologies $\ldots \ldots \ldots \ldots \ldots \ldots \ldots \ldots \ldots \ldots, \ldots \ldots$

4.1.2.1 Coal Cleaning ................................ 45

4.1.2.2 Briquettes ................................. 45

4.1.2.3 Combustion Modification for $\mathrm{NO}_{\mathrm{x}}$ Control $\ldots \ldots \ldots \ldots \ldots \ldots . \ldots 46$

4.1.2.4 Clean Coal Technologies ..........................46

4.1.2.5 Flue-Gas Desulfurization ........................... 47

4.1.2.6 Particulate Control .............................48 48

4.1.2.7 Postcombustion $\mathrm{NO}_{\mathrm{x}}$ Control $\ldots \ldots \ldots \ldots \ldots \ldots \ldots \ldots \ldots \ldots \ldots$

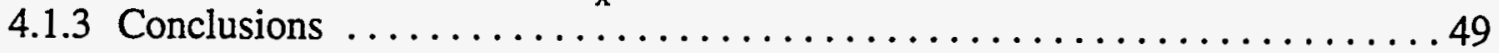

4.2 Water Pollution ............................................. 50

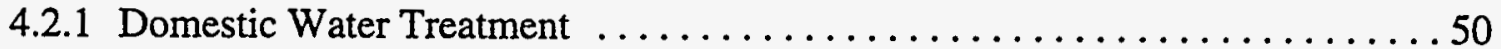

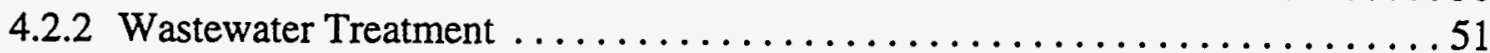

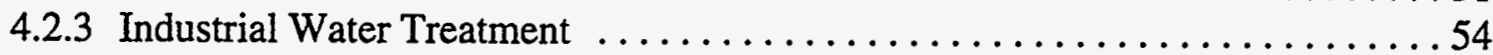

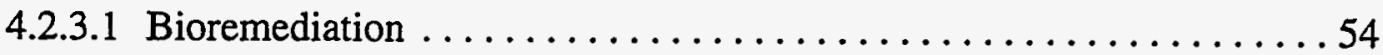

4.2.3.2 Physical Treatment ................................ 56

4.2.3.3 Chemical Treatment ............................. 57

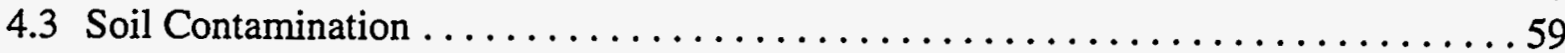

4.3.1 Organic Compounds ................................. 59

4.3.1.1 Soil Vapor Extraction ............................. 59

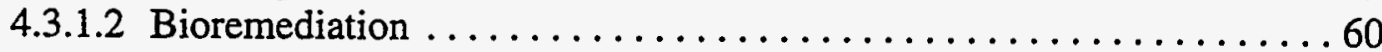

4.3.1.3 Incineration .................................61

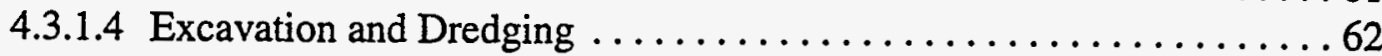

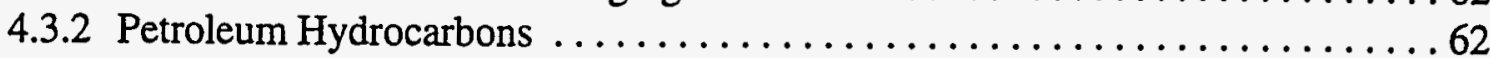

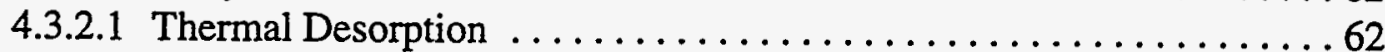

4.3.2.2 In Situ Biodegradation ..............................6. 64

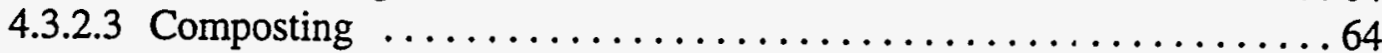

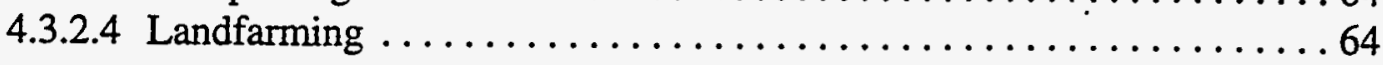




\section{CONTENTS (Cont.)}

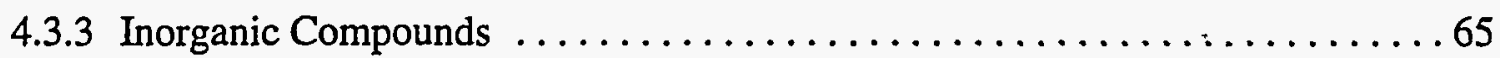

4.3.3.1 Ex Situ Solidification and Stabilization ..................6 65

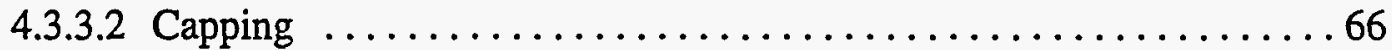

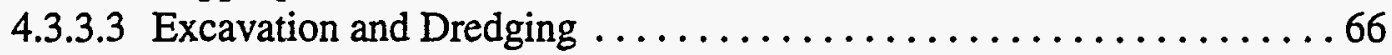

5 COSTS OF POLLUTION CONTROLS IN CHINA $\ldots \ldots \ldots \ldots \ldots \ldots \ldots \ldots \ldots \ldots \ldots$

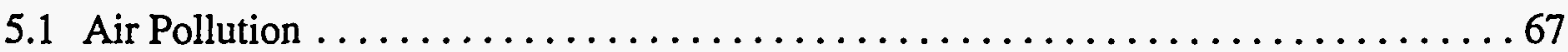

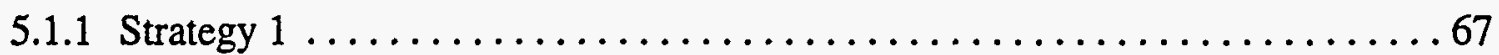

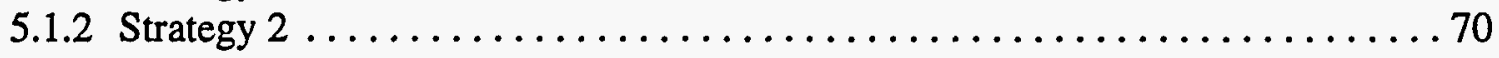

5.1.3 Options for Future Generating Capacity $\ldots \ldots \ldots \ldots \ldots \ldots \ldots \ldots \ldots \ldots \ldots \ldots \ldots$

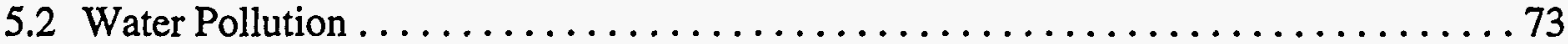

5.2.1 Domestic Water .................................. 73

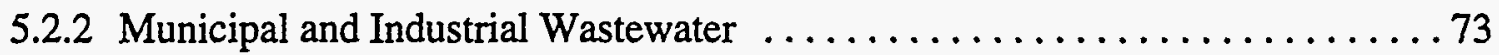

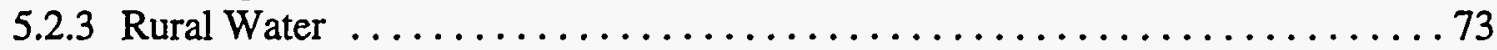

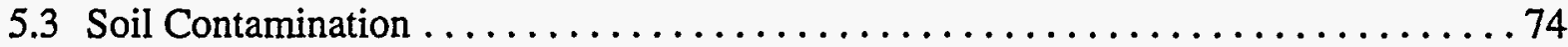

5.3.1 Organic Compounds and Petroleum Hydrocarbons . . . . . . . . . . . . 74

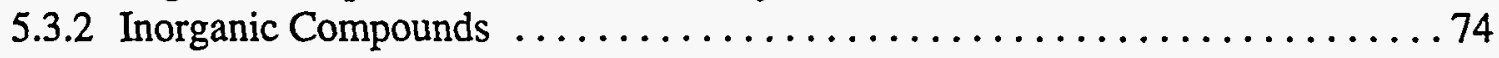

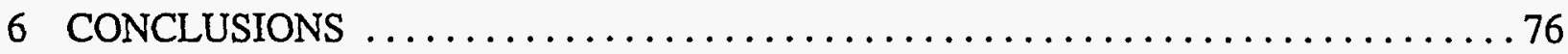

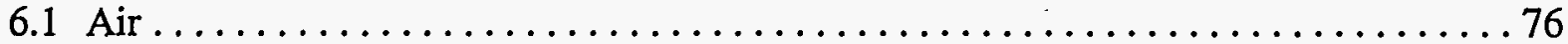

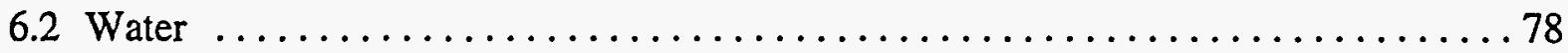

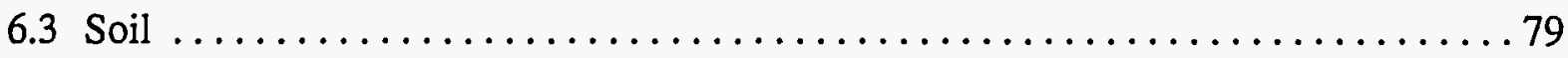

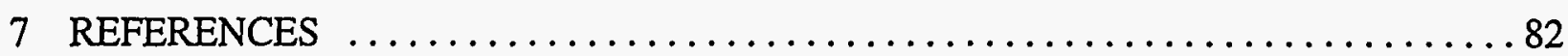

APPENDIX A: U.S. Water Quality Criteria and World Health Organization Guidelines for Drinking Water Quality $\ldots \ldots \ldots \ldots \ldots \ldots \ldots \ldots \ldots 7$

APPENDIX B: Surface Water Quality Limits for the Public Water Supply in the United States

\section{TABLES}

1 Major Sources of Air Pollutants in China, in Order of Their Relative

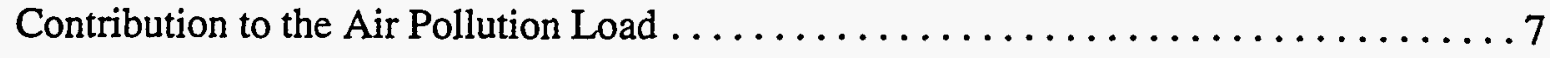

2 Major Sources of Water Pollutants in China, in Order of Their Relative Contribution to the Water Pollution Load 


\section{TABLES (Cont.)}

3 Major Sources of Soil Degradation in China, in Order of Their Relative

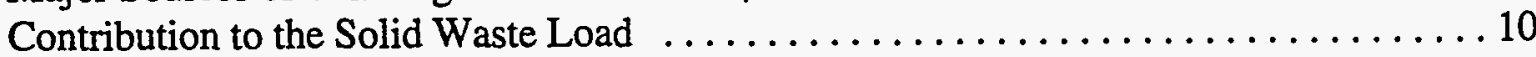

4 General Locations of Pollutant Sources in China $\ldots \ldots \ldots \ldots \ldots \ldots \ldots \ldots \ldots \ldots \ldots$

5 Emission and Discharge Levels of Selected Pollutants in China .............. 13

6 General Concentrations of Selected Pollutants in the Air and Water of China ....... 14

7 Resources at Risk from Various Pollutants and the Associated Impacts in China . . . . . 15

8 General Location of Receptors at Risk to Various Pollutants in China ........... 23

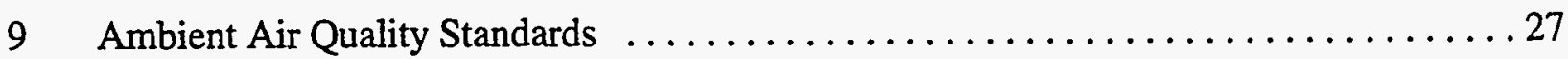

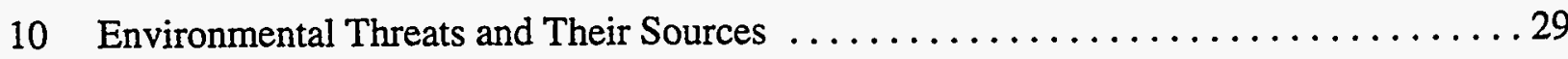

11 Air Pollution Levels during Acute Episodes in Various Cities and Current

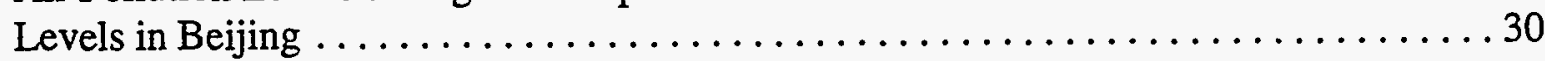

12 Processes and Treatment Systems Used to Remove the Major Contaminants

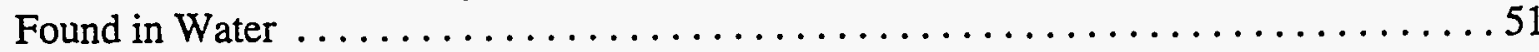

13 Processes and Treatment Systems Used to Remove the Major Contaminants

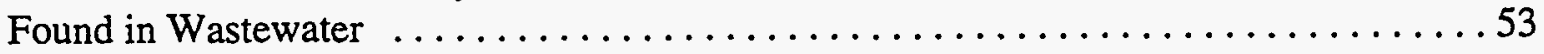

14 Conventional Excavation Techniques ............................6 63

15 Strategy 1: Cost and Pollution Reduction Achieved .....................69 69

16 Strategy 2: Cost and Pollution Reduction Achieved $\ldots \ldots \ldots \ldots \ldots \ldots \ldots \ldots \ldots \ldots$

17 Installed Generating Capacity by Fuel Type and Year $\ldots \ldots \ldots \ldots \ldots \ldots \ldots \ldots \ldots \ldots \ldots$

A.1 U.S. Water Quality Criteria and World Health Organization Guidelines for Drinking Water Quality

B.1 Surface Water Quality Limits for the Public Water Supply in the United States 


\section{FIGURES}

1 Areas at Highest Risk from Damage Caused by Anthropogenic Activities and

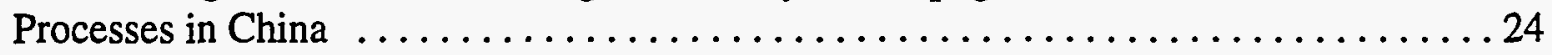

2 Flow Diagram of Complete Treatment of River Water $\ldots \ldots \ldots \ldots \ldots \ldots \ldots \ldots$

3 Typical Flow Diagram of Wastewater Treatment and Reclamation ............. 55 


\title{
ENVIRONMENTAL PROBLEMS IN THE PEOPLE'S REPUBLIC OF CHINA: CURRENT MAGNITUDE AND POSSIBLE CONTROL OPTIONS
}

\author{
by
}

N. Bhatti, C.A. Biang, L.A. Poch, and M.M. Tompkins

\begin{abstract}
The People's Republic of China has been undergoing rapid economic development over the past several decades. This development has taken place with little or no attention being paid to its environmental consequences. This situation has resulted in severe contamination of the air, water, and soil resources of China, with attendant damage to human and natural populations. This report determines the major causes of air, water, and soil pollution in China and assesses their extent and magnitude. It then examines the impacts of the pollutants on various components of the human and natural environment. It identifies possible regulatory and ameliorative options available to China to deal with these pollution problems and provides information on specific strategies and the costs associated with their implementation. The objective is to shed light on China's pollutioncontrol and remediation requirements in the near future.
\end{abstract}

\section{INTRODUCTION}

The People's Republic of China (hereinafter referred to as China) is currently undergoing rapid economic development and industrialization. This economic expansion has been accompanied by a large growth in population. Although such a rate of growth is not especially high when compared with that of developing countries, in absolute terms, large numbers of people have been added to the total population. During just the last 40 years, China's population increased by 602 million people. The rapid economic development has caused an exodus of the rural population to urban areas, which, in turn, has resulted in the growth of the industrial sector of the economy at the expense of the traditional agricultural sector. The industrial sector now dominates the country's gross domestic product (GDP), with industry and manufacturing accounting for $56 \%$ of China's GDP in 1990. Agricultural production has decreased significantly over the past half century, and in 1990 , it accounted for only $22 \%$ of the country's GDP. 
This shift in dominance from agriculture to industrial production has resulted in a significant increase in the use of energy resources and production of environmental pollutants. In addition, the resource distortions caused by policies of the centrally planned government have exacerbated China's environmental problems. Subsidized prices for many raw materials - including coal, water, timber, and minerals - have resulted in overuse, misuse, and waste. Coal production and consumption have come to dominate the energy sector; thus, the environmental impacts associated with energy consumption have become closely related to the use of coal. Many of China's environmental efforts have therefore focused on preventing and controlling any negative environmental consequences of coal use and on promoting greater efficiency in the use of energy resources.

The environmental impacts associated with coal use in China and the economic impacts of constraints on its use are described in detail in Volume 1 (Bhatti et al. 1994) and Volume 2 (Rose et al. 1994), respectively, of an Argonne report on coal use in China, prepared as part of Phase I of this project. This report instead focuses on the extent of air, water, and soil pollution in China resulting from all major activities in all sectors, not just from those related to coal use. These sectors and activities include the energy sector in general; the industrial, residential, commercial, and transportation sectors; agricultural activities; waste production; sewage treatment; and land use changes. This report then uses the information on the magnitude of the environmental problems in China to develop recommendations on the most effective and realistic levels of environmental control for this country, under both current and future conditions. The pollution control and remediation technologies needed to meet these control objectives are identified and described. The economic implications of implementing these technologies are also discussed and estimated. This information can be used to obtain a better understanding of China's pollution control and remediation needs. These needs are likely to play a significant role in China's continued economic development, aid requests, technology purchases, and environmental policymaking.

Section 2 of this report provides an overview of the current state of the environment in China. The major pollutants of concern and the main sources of these pollutants are identified, along with their locations. Their potential impacts on human health, agriculture, forests, water and coastal resources, and other environmental components are then assessed. Section 3 discusses the regulatory and ameliorative options available to China to address these pollution problems. Many of these problems resemble those experienced by the United States during its early period of industrialization. Thus, the early U.S. experience in addressing these issues is described, since China could follow a similar path in dealing with its own environmental problems. Some possible strategies to deal with the most pressing of these problems are also identified. Section 4 provides information on appropriate technical control options for air, water, and soil pollution that could be adopted by the Chinese. Only readily available technologies that are relatively inexpensive and simple to operate and maintain are included. The costs of implementing the strategies identified in Section 3 by using some of the technologies described in Section 4 are estimated and discussed in Section 5. 


\section{ENVIRONMENTAL IMPACTS OF COAL USE, OTHER ENERGY USE, AND INDUSTRIAL ACTIVITIES IN CHINA}

\subsection{STATE OF THE ENVIRONMENT IN CHINA}

Rapid population growth, expanding economic development, and an accelerating rate of urbanization have placed extreme pressures on the natural environment in China. A growing amount of organic waste and inorganic effluent inputs in water and soil systems, atmospheric emissions, soil erosion, accumulation of solid wastes, deforestation, and loss of biodiversity are but a few causes of this deterioration of the Chinese environment. In general, the environmental problems experienced by the Chinese today are the result of an accelerating consumption of natural resources coupled with an inability to properly dispose of the wastes that emanate from this consumption. This section identifies the major pollutants of concern in China, the main sources and locations of these pollutants, and both the impacts that are currently associated with these pollutants and those that are likely to occur if population and economic growth continue as generally predicted.

The economy of China has been growing at a rate of 14-15\%/yr during the past decade (WER 1993, 1994a). This rapid economic growth, with its attendant improvement in living conditions for China's growing population, has led to greatly increased production and consumption of consumer goods and thereby greatly increased the generation of production-related pollutants and postconsumer wastes. Because most of this increased economic activity has been confined to urban areas, people from the rural parts of China have migrated to such areas. The rapid rate of growth of urban areas and the general absence of pollution control measures make it likely that environmental problems (with the exception of regional/global environmental problems) will be much more severe in the urban areas than the rural parts of China.

\subsection{POLLUTANTS OF CONCERN}

The types of pollutants released into the Chinese environment vary widely, with the known forms of pollutants numbering in the thousands at present. However, some substances discharged into the environment have not yet been tested for toxicity and risks; thus, the number of commercially available chemicals that could affect various components of the environment might be even larger. It is estimated that more than 100,000 commercially available chemicals are currently in use worldwide (UNEP 1994). From an environmental perspective, it would be more accurate to consider the release of a pollutant into all media and/or to study pollutants in combination. However, for logistical simplicity, pollutants are usually studied in terms of the media into which they are released. This latter approach is used in this report. 


\subsubsection{Air}

Pollutants emitted into the atmosphere can have a wide range of effects; that is, these effects can be local, regional, or global. All of these impacts must be considered. Although a large number of pollutants are released into the atmosphere in China, this report deals with only those that are of the greatest importance in terms of volume emitted, degree of risk involved, or amount of information available.

The air pollutants addressed in this report include the following:

- Sulfur dioxide $\left(\mathrm{SO}_{2}\right)$;

- Nitrogen oxides $\left(\mathrm{NO}_{x}\right)$, including nitric oxide $(\mathrm{NO})$ and nitrogen dioxide $\left(\mathrm{NO}_{2}\right)$;

- Methane $\left(\mathrm{CH}_{4}\right)$;

- Carbon dioxide $\left(\mathrm{CO}_{2}\right)$;

- Carbon monoxide (CO);

- Particulates, including toxic substances;

- Air toxics;

- Hydrocarbons;

- Chlorofluorocarbons (CFCs); and

- Volatile organic compounds (VOCs).

\subsubsection{Water}

A large quantity of pollutants are discharged directly into water systems in China. In addition, a large number of pollutants reach water bodies via leaching from waste and storage sites. Water pollution problems are exacerbated by the uneven distribution of rainfall in China, which often results in flooding and drought conditions that can lead to the spreading and concentration of pollutants. 
The major pollutants of concern that are discharged into waterways in China include these:

- Organic matter;

- Suspended matter, such as toxic solids; and

- Bacteria and other pathogens.

Arsenic, mercury, chlorinated hydrocarbons, pesticides, oils, nitrogen, and phosphorus are the main substances that are often released into water systems.

\subsubsection{Land/Solid Wastes}

Anthropogenic activities are rapidly degrading and depleting the soil resources in China. However, pollution of this medium has received relatively little attention when compared with the attention given to deterioration of water and atmospheric systems. Chemical deterioration of soils and sediments can arise from direct discharge to soil systems or from indirect transport to soils and sediments from the air and water components of the environment. In general, soils and sediments serve as sinks for a large number of substances released through anthropogenic activities and are the ultimate repository for many pollutants. The list of pollutants of concern with respect to soil and sediment resources is long and includes the following:

- Pesticides;

- Trace and heavy metals, such as $\mathrm{Zn}, \mathrm{Cu}, \mathrm{Fe}, \mathrm{Ar}, \mathrm{Mn}, \mathrm{Vn}, \mathrm{Cd}, \mathrm{Hg}, \mathrm{Pb}$, and $\mathrm{Ni}$;

- Oils;

- Organic substances, including polychlorinated compounds;

- Acids, including deposition of sulfuric and nitric acids in precipitation;

- Salts; and

- Radionuclides, such as cesium-137 and strontium-90. 


\subsection{SOURCES}

It is obvious that a large number of different pollutants are discharged into Chinese air, water, and soil resources. A wide variety of anthropogenic activities result in this discharge. Some of the major ones are described below.

\subsubsection{Air}

China's heavy reliance on coal as an energy source, its lack of pollution control devices, and the high ash content of Chinese coal make the coal fuel cycle, particularly the combustion step, the major anthropogenic source of air pollutants in this country. (For a more detailed description of the coal fuel cycle and the pollutants associated with various steps of this cycle, see Bhatti et al. 1994). Unlike the situation in most other nations (particularly the industrialized countries of the West, where coal is used almost exclusively in the electric utility sector), in China, coal has a wide user base. It is consumed predominantly in the industrial sector, but significant quantities are also used by the electrical utility sector, individual households, and the commercial sector. This dispersed use of coal in relatively large numbers of small boilers often results in the inefficient and incomplete combustion of coal minerals, a situation that increases the amount of various pollutants released into the atmosphere.

It has been estimated that $75 \%$ of the particulate matter emitted by anthropogenic activities into the atmosphere results from coal combustion (Fengqi 1992). Coal contains heavy and trace metals that are often discharged into the air (in the form of suspended particulate matter) upon the incomplete combustion of coal. The majority of the suspended particulate matter in urban areas is composed of benzo(a)pyrene, lead, cadmium arsenic, and benzene (Zhao and Sun 1986). In addition, $90 \%$ of the $\mathrm{SO}_{2}$ and $67 \%$ of the $\mathrm{NO}_{\mathrm{x}}$ released from man-made sources (excluding biomass emissions) can also be attributable to the combustion of coal, mainly by large numbers of small and medium-sized coal-burning stoves and furnaces (Travis 1991). Hydrocarbon and VOC emissions also result from coal use, particularly from the inefficient combustion processes that are common in China. Furthermore, $\mathrm{CH}_{4}$ gas can be released during various steps of the coal fuel cycle, particularly during the extraction process. Radionuclides are also present in coal and can be emitted into the atmosphere when coal is burned.

The combustion of coal also results in the release of $\mathrm{CO}_{2}$. All commercial fuels (as well as traditional fuels) emit $\mathrm{CO}_{2}$ upon combustion, but coal releases more $\mathrm{CO}_{2}$ per unit of energy produced than any other fuel when burned.

Although coal combustion is the largest anthropogenic source of air pollution in China, the use of other fossil fuels also contributes to the air pollutant load, especially in urban areas. The combustion of oil or natural gas releases significant quantities of $\mathrm{CO}_{2}$; oil burning also results in the 
discharge of $\mathrm{SO}_{2}$, particulates, and $\mathrm{NO}_{\mathrm{x}}$. The production/extraction, distribution, and consumption activities associated with natural gas can result in the emission of significant quantities of $\mathrm{CH}_{4}$. Gasoline storage, transport, and consumption are responsible for a substantial portion of the $\mathrm{NO}_{\mathrm{x}}$ and VOC emitted into the atmosphere.

Industrial activity in China has increased rapidly during the past few decades and has led to a steady rise in the contribution of the industrial sector to the air pollutant load in this country. In addition to those emissions released as a result of the energy-related needs associated with industrial activities, industrial processes themselves are responsible for emitting a wide variety of pollutants into the air. Other sectors, such as the transportation sector, also add to the pollutant mix in the atmosphere. The major sectors and activities and the main pollutants associated with each are listed in Table 1. The sectors are listed in order of their importance in contributing to the overall air pollutant load.

TABLE 1 Major Sources of Air Pollutants in China, in Order of Their Relative Contribution to the Air Pollution Load

Process/Activity

Pollutant

Coal combustion by electric utilities and industrial and residential boilers

Petrochemical industries

Iron and steel manufacturing

Smelters

Incinerators

Mining

Motor vehicle use

Agriculture

Land use changes

Fuelwood burning

Landfills

Organic chemical manufacturers

Construction activities

Solvent use

Sewage treatment

Use of aerosols, refrigerants, foam-blowing agents, fire extinguishers
$\mathrm{SO}_{2}, \mathrm{NO}_{x}$, particulates, $\mathrm{CO}_{2}$, air toxics, VOCs, organic compounds

$\mathrm{CH}_{4}, \mathrm{SO}_{2}$, air toxics, $\mathrm{CO}_{2}$

$\mathrm{SO}_{2}$, air toxics, $\mathrm{NO}_{\mathrm{x}}$, particulates, $\mathrm{CO}_{2}$

$\mathrm{SO}_{2}, \mathrm{NO}_{\mathrm{x}}, \mathrm{CO}_{2}$

Particulates, air toxics, $\mathrm{CO}_{2}, \mathrm{CO}, \mathrm{NO}_{\mathrm{x}}$, heavy metals, trace organics

Particulates, $\mathrm{CH}_{4}$

VOCs, $\mathrm{NO}_{\mathrm{x}}$, particulates, $\mathrm{CO}_{2}, \mathrm{CO}$, air toxics, $\mathrm{Pb}$

$\mathrm{CH}_{4}, \mathrm{NO}_{\mathrm{x}}, \mathrm{NH}_{3}, \mathrm{CO}_{2}$, pesticides, organochlorines

$\mathrm{CO}_{2}$, particulates, $\mathrm{CH}_{4}$, VOCs

VOCs, $\mathrm{CO}_{2}, \mathrm{CO}$, particulates, $\mathrm{NO}_{\mathrm{x}}$

$\mathrm{CH}_{4}$, VOCs, air toxics

VOCs, air toxics, trace organics

Particulates, $\mathrm{CO}_{2}$

VOCs

$\mathrm{CH}_{4}$

Halocarbons 


\subsubsection{Water}

Water pollution problems are also severe in China; a large number of sources contribute to the degradation of this resource. Unlike the situation for air pollution, the predominant source of water pollution in this country is not the energy sector. Energy production and consumption activities are responsible for a significant share of the water pollutant load, but other sources are even more important in many cases.

The major water pollution sources are pulp and paper mills, chemical manufacturing facilities, petrochemical plants, refineries, metalworking installations, textile mills, and municipal facilities. Various steps of the coal fuel cycle, particularly the extraction, preparation, and consumption stages, also lead to contamination of water resources. In addition, the consumption step of the coal fuel cycle can result in thermal pollution of water systems. Indirect contamination of water resources can also occur and usually involves the deposition of pollutants, both from the atmosphere and from rainout of atmospheric pollutants.

Only a very small proportion of the water used in China is treated and recycled to any extent. More than $80 \%$ of the wastewater is discharged into waterways without being treated at all.

Some of the most significant activities responsible for contributing to the water pollutant load in china and the main pollutants released by each are listed in Table 2 . The sectors are listed in order of their importance in contributing to the overall water pollutant load.

\subsubsection{Land/Solid Wastes}

Soils and sediments are not an infinite resource; like air and water systems, they are resources that can be lost and/or degraded through anthropogenic activities. This situation is especially true in China. Its large population and high economic growth rate, with its heavy emphasis on industrial activities to fuel this growth, have led to the generation of vast quantities of solid wastes. In general, these wastes have been discharged into landfills, thereby damaging underlying and adjacent soil systems. In addition, coal mining and combustion, land-use changes, and agricultural activities have further degraded soil systems.

Soil degradation can occur through a number of different pathways, including these:

- Erosion by water and wind,

- Nutrient depletion, 
TABLE 2 Major Sources of Water Pollutants in China, in Order of Their Relative Contribution to the Water Pollution Load

Activity/Process

Pollutant

Mining

Agricultural production

Industrial processes (e.g., petrochemical, textile, and metalworking industries)

Toxic chemicals including heavy metals, acids, sediments, suspended solids

Sediments, suspended solids, pesticides, salts, herbicides, nutrients (fertilizers)

Toxic chemicals including heavy metals, acids, bases, oils, thermal pollution

Land use changes

Sediments, suspended solids, nutrients

Electric utilities

Toxic metals, acids, bases, oils, thermal pollution

Pulp and paper mills

Toxic chemicals including heavy metals, organic substances

Municipal wastewater systems

Nutrients, sediments, suspended solids, pathogenic microbes

Atmospheric deposition

Acids, organochlorines, pesticides, heavy metals

- Physical deterioration, such as compaction and waterlogging; and

- Chemical contamination, such as salinization and acidification.

As stated earlier, soils act as sinks for many substances released by industrial processes and other human activities and are a repository for these substances regardless of whether such pollutants were initially discharged into the air, water, or directly into the soil system.

The major activities contributing to degradation of soils and sediments and the type of degradation attributable to each are listed in Table 3. The sectors are listed in order of their importance in contributing to the overall solid waste pollutant load.

\subsection{LOCATION OF SOURCES}

To determine the impacts that various energy-related and non-energy-related processes have on different components of the environment in China, it is necessary to identify not only the types of pollutants involved but also the location of the major sources, particularly in relationship to human population centers and vulnerable resources. The spatial distribution of the major sources of pollutants as identified above varies considerably with the particular activity or process involved. Some activities are located in very localized and specific areas, whereas others are scattered 
TABLE 3 Major Sources of Soil Degradation in China, in Order of Their Relative Contribution to the Solid Waste Load

Coal mining, preparation, and consumption

Agricultural activities

Land use changes

Industrial activities

Construction activities

Landfills

Motor vehicles

Incinerators

Municipal waste treatment plants

Nuclear weapons testing
Chemical contamination with toxic substances $(\mathrm{Ar}, \mathrm{Pb}, \mathrm{Cd}, \mathrm{Cr}, \mathrm{Hg}$ ), acids, organic compounds (dioxins, furans), and radioactive substances

Acidification

Physical deterioration such as subsidence, waterlogging, compaction

Physical deterioration, including compaction and waterlogging

Chemical contamination with pesticides, herbicides, and fertilizers

Salinization and acidification

Wind and water erosion

Nutrient depletion

Physical deterioration, including compaction and waterlogging

Wind and water erosion

Nutrient depletion

Chemical contamination with toxic substances, including heavy metals, oils, acids, organic compounds

Physical deterioration, including compaction and waterlogging

Wind and water erosion

Chemical contamination, especially lead

Chemical contamination

Chemical contamination with heavy metals, especially lead and cadmium

Physical deterioration, including compaction

Chemical contamination with heavy metals and organic substances such as dioxin and furans

Chemical contamination (from soil application of sludge) with heavy metals and organic substances

Contamination with radionuclides and heavy metals 
throughout the country. Given the large numbers of different types of activities and processes involved in contributing to the pollutant load of the air, water, and soils in China, it is possible to identify the spatial distribution of source types on only a very general scale. Although a given pollutant may be emitted or discharged in one area, its impact may occur some distance from the source because of the long-range transport of many contaminants.

The general locations of major pollutant sources are listed in Table 4. Most sources are usually located in or around urban centers. For example, 5,700 industrial enterprises (including utility plants) are located in the greater Beijing area, including the following: 24 power plants, 28 nonferrous smelters, 25 ferrous smelters, 194 chemical plants, 18 coking plants, 483 metal products factories, and 1 major iron and steel complex.

\subsection{POLLUTANT LEVELS IN CHINA}

The information provided in Sections 1.2, 1.3, and 1.4 indicates that a variety of pollutants and sources are responsible for contributing to the pollutant load of the air, water, and soil systems in various parts of China. However, it is necessary to know the concentration of these pollutants in various media to determine if these pollutants and their sources could result in significant impacts to the environment and to human health. Some information is available on emission and discharge levels for various pollutants, but this information is limited. Monitoring activities to identify the ambient concentrations of various contaminants in the air, water, and soils are even more limited. Thus, very little information is currently available on pollutant concentrations in the air, water, and soils in China. Emission and discharge quantities of some of the main pollutants are listed in Table 5.

Pollutant concentrations for some of the major pollutants have been determined from the few monitoring studies that have been undertaken (mostly from global networks). These levels are listed in Table 6.

\subsection{SENSITIVE RECEPTORS AND POTENTIAL IMPACTS}

The pollutants described in the above sections become a matter of concern only if and when they come into contact and/or have the potential to harm receptors that are sensitive to the pollutant question and have value to society. These receptors can be natural or anthropogenic and include sensitive human populations. The resources at risk from various pollutants and the impacts associated with these receptors are listed in Table 7. The most significant of these impacts on individual sectors are described in more detail below. 
TABLE 4 General Locations of Pollutant Sources in China

\begin{tabular}{|c|c|c|}
\hline Activity & Pollutants Involved & $\begin{array}{l}\text { Location of Majority of } \\
\text { Sources }\end{array}$ \\
\hline Coal mining/extraction & $\begin{array}{l}\text { Air (minor): } \mathrm{CH}_{4}, \mathrm{CO}_{2}, \mathrm{CO} \text {, } \\
\text { particulates, air toxics } \\
\text { Water: acids, heavy metals, } \\
\text { suspended solids } \\
\text { Land: chemical contamination, } \\
\text { physical deterioration }\end{array}$ & North-central portion of China \\
\hline $\begin{array}{l}\text { Coal processing/ } \\
\text { consumption/ } \\
\text { postconsumption }\end{array}$ & $\begin{array}{l}\text { Air (major): particulates, } \mathrm{SO}_{2} \text {, } \\
\mathrm{NO}_{x}, \mathrm{CO}_{2}, \mathrm{CO} \text {, hydrocarbons, } \\
\text { VOCs, metals, radionuclides } \\
\text { Water: thermal pollution, metals, } \\
\text { acids, bases, oils } \\
\text { Land: chemical contamination }\end{array}$ & $\begin{array}{l}\text { North and central coastal } \\
\text { regions from Shenyang to } \\
\text { Shanghai }\end{array}$ \\
\hline Industrial activity & $\begin{array}{l}\text { Air: } \mathrm{CO}_{2}, \mathrm{SO}_{2}, \mathrm{NO}_{\mathrm{x}}, \mathrm{VOCs} \text {, air } \\
\text { toxics, } \mathrm{CH}_{4}, \mathrm{CFCs} \\
\text { Water: toxic chemicals, acids, } \\
\text { bases, organic substances, } \\
\text { oils, thermal pollution } \\
\text { Land: chemical contamination }\end{array}$ & $\begin{array}{l}\text { North and central coastal } \\
\text { regions from Shenyang to } \\
\text { Shanghai; Chongking area; } \\
\text { coastal region adjacent to Hong } \\
\text { Kong; Liaoning Province }\end{array}$ \\
\hline Agricultural activity & $\begin{array}{l}\text { Air: } \mathrm{CH}_{4}, \mathrm{NO}_{\mathrm{x}}, \mathrm{NH}_{3} \text {, pesticides, } \\
\text { organic substances } \\
\text { Water: suspended solids, salts, } \\
\text { pesticides, herbicides, nutrients } \\
\text { Land: physical deterioration, } \\
\text { chemical contamination, wind } \\
\text { and water erosion, nutrient } \\
\text { depletion, salinization }\end{array}$ & $\begin{array}{l}\text { Eastern and southern coastal } \\
\text { areas, eastern plains }\end{array}$ \\
\hline Land use changes & $\begin{array}{l}\text { Air: } \mathrm{CO}_{2} \text {, particulates, } \mathrm{CH}_{4} \text {, VOCs } \\
\text { Water: sediments and suspended } \\
\text { solids, nutrients } \\
\text { Land: physical deterioration,wind } \\
\text { and water erosion, nutrient depletion }\end{array}$ & $\begin{array}{l}\text { Various parts of China but } \\
\text { concentrated in coastal regions } \\
\text { and the eastern plains }\end{array}$ \\
\hline Sewage treatment & $\begin{array}{l}\text { Air: } \mathrm{CH}_{4} \\
\text { Water: nutrients, sediments, } \\
\text { pathogenic microbes } \\
\text { Land: chemical contamination }\end{array}$ & $\begin{array}{l}\text { Urban areas and population } \\
\text { centers }\end{array}$ \\
\hline Landfills & $\begin{array}{l}\text { Air: } \mathrm{CH}_{4} \text {, VOCs, air toxics } \\
\text { Water: leaching of various } \\
\text { contaminants } \\
\text { Land: chemical contamination }\end{array}$ & $\begin{array}{l}\text { Vicinity of population centers } \\
\text { and in urban areas }\end{array}$ \\
\hline
\end{tabular}


TABLE 4 (Cont.)

\begin{tabular}{|c|c|c|}
\hline Activity & Pollutants Involved & $\begin{array}{c}\text { Location of Majority of } \\
\text { Sources }\end{array}$ \\
\hline Motor vehicles & $\begin{array}{l}\text { Air: VOCs, } \mathrm{NO}_{\mathrm{x}} \text {, particulates, } \mathrm{CO}_{2} \text {, } \\
\mathrm{CO} \text {, air toxics especially } \mathrm{Pb} \\
\text { Water: minor } \\
\text { Land: chemical contamination, } \\
\text { physical deterioration }\end{array}$ & $\begin{array}{l}\text { Urban areas and along major } \\
\text { transportation corridors }\end{array}$ \\
\hline Incinerators & $\begin{array}{l}\text { Air: particulates, air toxics, } \\
\mathrm{CO}_{2}, \mathrm{CO}, \mathrm{NO}_{\mathrm{x}} \\
\text { Water: minor } \\
\text { Land: chemical contamination }\end{array}$ & Urban areas \\
\hline Fuelwood burning & $\begin{array}{l}\text { Air: VOCs, } \mathrm{CO}_{2}, \mathrm{CO}, \mathrm{NO}_{\mathrm{x}} \text {, } \\
\text { particulates } \\
\text { Water: minor } \\
\text { Land: ash }\end{array}$ & Rural areas mainly \\
\hline Construction activity & $\begin{array}{l}\text { Air: particulates, } \mathrm{CO}_{2} \\
\text { Water: sediments } \\
\text { Land: physical deterioration, } \\
\text { wind and water erosion }\end{array}$ & $\begin{array}{l}\text { Urban areas, especially rapidly } \\
\text { growing cities }\end{array}$ \\
\hline Nuclear weapons testing & $\begin{array}{l}\text { Air: radionuclides, particulates } \\
\text { Water: radionuclides } \\
\text { Land: radionuclides }\end{array}$ & Remote western deserts \\
\hline
\end{tabular}

TABLE 5 Emission and Discharge Levels of Selected Pollutants in China ${ }^{a}$

\begin{tabular}{|c|c|c|c|}
\hline Medium & Pollutant & $\begin{array}{c}\text { Emission/Discharge } \\
(1990)\end{array}$ & $\begin{array}{l}\text { U.S. Emission/ } \\
\text { Discharge }\end{array}$ \\
\hline \multirow{6}{*}{$\begin{array}{l}\text { Air } \\
\text { (UNEP 1993) }\end{array}$} & $\mathrm{CO}_{2}$ & $678.0 \times 10^{6} \mathrm{tC} / \mathrm{yr}$ & $1,310.3 \times 10^{6} \mathrm{C} / \mathrm{yr}$ \\
\hline & $\mathrm{CH}_{4}$ & $52.4 \times 10^{6} \mathrm{t} / \mathrm{yr}(1980 \mathrm{~s})$ & $32.7 \times 10^{6} \mathrm{t} / \mathrm{yr}$ \\
\hline & $\mathrm{CFC}$ (consumption) & $53.3 \times 10^{3} \mathrm{t} / \mathrm{yr}$ & $145.6 \times 10^{3} \mathrm{t} / \mathrm{yr}$ \\
\hline & $\mathrm{SO}_{2}$ & $19.9 \times 10^{6} \mathrm{t} / \mathrm{yr}$ & $21.1 \times 10^{6} \mathrm{t} / \mathrm{yr}$ \\
\hline & $\mathrm{NO}_{x}$ & $7.4 \times 10^{6} \mathrm{t} / \mathrm{yr}$ & $19.8 \times 10^{6} \mathrm{t} / \mathrm{yr}$ \\
\hline & Particulates & $14-17 \times 10^{6} \mathrm{t} / \mathrm{yr}$ & $10-11 \times 10^{6} \mathrm{t} / \mathrm{yr}$ \\
\hline $\begin{array}{l}\text { Water } \\
\text { (WuDunn 1993) }\end{array}$ & Industrial wastes & $\begin{array}{l}23 \times 10^{9} \mathrm{t} \text { discharged } \\
\text { directly into waterways }\end{array}$ & \\
\hline
\end{tabular}

a $\mathrm{t}=$ metric ton $(2,200 \mathrm{lb}), \mathrm{C}=$ carbon. 
TABLE 6 General Concentrations of Selected Pollutants in the Air and Water of China

\begin{tabular}{|c|c|c|c|c|c|}
\hline Media & $\begin{array}{l}\text { Site, Year, and } \\
\text { Source }\end{array}$ & Pollutant & $\begin{array}{l}\text { Concentration } \\
\text { (air: } \mu \mathrm{g} / \mathrm{m}^{3} \text { ) } \\
\text { (water: } \mathrm{mg} / \mathrm{L} \text { ) }\end{array}$ & $\begin{array}{c}\text { U.S. } \\
\text { Standard } \\
\left(\mu \mathrm{g} / \mathrm{m}^{3}\right)\end{array}$ & $\begin{array}{l}\text { Typical } \\
\text { Levels } \\
\left(\mu \mathrm{g} / \mathrm{m}^{3}\right) \\
\end{array}$ \\
\hline \multirow[t]{12}{*}{ Air } & \multirow[t]{4}{*}{$\begin{array}{l}\text { Beijing } 1990 \\
\text { (1) }\end{array}$} & $\mathrm{SO}_{2}$ & $\begin{array}{l}\text { Mean: } 25-130 \\
\text { Max: } 682\end{array}$ & 80 & 10 (U.S.) \\
\hline & & Particulates & $\begin{array}{l}\text { Mean: } 250-410 \\
\text { Max: } 1286\end{array}$ & 75 & 50-60 (U.S.) \\
\hline & & $\mathrm{NO}_{\mathrm{x}}$ & $\begin{array}{l}\text { Mean: } 14-54 \\
\text { Max: } 76\end{array}$ & 100 & \\
\hline & & $\mathrm{O}_{3}$ & Max: 320 & 235 & \\
\hline & \multirow[t]{3}{*}{$\begin{array}{l}\text { Shenyang } 1982 \\
(2,3)\end{array}$} & $\mathrm{SO}_{2}$ & $\begin{array}{l}\text { Mean: } 132 \\
\text { Dec. mean: } 691\end{array}$ & & \\
\hline & & Particulates & $\begin{array}{l}\text { Mean: } 470 \\
\text { Dec. mean: } 769\end{array}$ & & \\
\hline & & $\mathrm{NO}_{\mathrm{x}}$ & $\begin{array}{c}\text { Mean: } 609 \text { (1982), } \\
60(1989)\end{array}$ & & \\
\hline & \multirow{2}{*}{$\begin{array}{l}\text { Shanghai } 1982 \\
\text { (2) }\end{array}$} & $\mathrm{SO}_{2}$ & Mean: 65 & & \\
\hline & & Particulates & Mean: 244 & & \\
\hline & \multirow{3}{*}{$\begin{array}{l}\text { Chongking } \\
1989 \text { (3) }\end{array}$} & $\mathrm{SO}_{2}$ & Mean: 340 & & \\
\hline & & $\mathrm{NO}_{\mathrm{x}}$ & Mean: 60 & & \\
\hline & & Particulates & Mean: 430 & & \\
\hline \multirow[t]{12}{*}{ Water } & \multirow{4}{*}{$\begin{array}{l}\text { Yangtze River } \\
1990(4)\end{array}$} & Suspended solids & 174.5 & & $18.2(\text { N.Z. })^{\mathrm{b}}$ \\
\hline & & Nutrients (nitrates) & 1.15 & & 0.36 (Japan) \\
\hline & & $\mathrm{BOD}^{\mathrm{a}}$ & 0.80 & & 0.90 (N.Z.) \\
\hline & & Fecal coliform & $865(\mathrm{no} . / 100 \mathrm{ml})$ & & 160 (N.Z.) \\
\hline & \multirow{4}{*}{$\begin{array}{l}\text { Yellow River } \\
1990 \text { (4) }\end{array}$} & Suspended solids & $6,822.0$ & & \\
\hline & & Nutrients (nitrates) & 2.48 & & \\
\hline & & BOD & 1.18 & & \\
\hline & & Fecal coliform & 2950 & & \\
\hline & \multirow{4}{*}{$\begin{array}{l}\text { Pearl River } \\
1990 \text { (4) }\end{array}$} & Suspended solids & 30.5 & & \\
\hline & & Nutrients (nitrates) & 0.70 & & \\
\hline & & $\mathrm{BOD}$ & 0.85 & & \\
\hline & & Fecal coliform & 205 & & \\
\hline
\end{tabular}

a $\mathrm{BOD}=$ biochemical oxygen demand.

b N.Z. = New Zealand.

Sources: (1) WHO/UNEP (1992); (2) Zhao and Sun (1986); (3) Sinton (1992); (4) UNEP (1993). 
TABLE 7 Resources at Risk from Various Pollutants and the Associated Impacts in China

\begin{tabular}{|c|c|c|}
\hline Resource & Pollutant & Effect \\
\hline \multirow[t]{6}{*}{ Forests, crops } & $\mathrm{SO}_{2}$ & $\begin{array}{l}\text { Foliar damage, reductions in growth and } \\
\text { yield }\end{array}$ \\
\hline & $\begin{array}{l}\mathrm{SO}_{2}, \mathrm{NO}_{x} \text {, and their acidic } \\
\text { products }\end{array}$ & $\begin{array}{l}\text { Foliar damage, reductions in growth, soil } \\
\text { chemistry changes, alterations in host- } \\
\text { pest/disease interactions }\end{array}$ \\
\hline & Ozone $\left(\mathrm{O}_{3}\right)$ & $\begin{array}{l}\text { Foliar damage/phytotoxicity, reductions in } \\
\text { growth, increased susceptibility to disease } \\
\text { and pests, reproduction abnormalities }\end{array}$ \\
\hline & Fluoride & $\begin{array}{l}\text { Reproduction abnormalities, reductions in } \\
\text { growth and yield }\end{array}$ \\
\hline & Particulates & Growth abnormalities \\
\hline & Heavy metals & $\begin{array}{l}\text { Foliar damage to older leaves, reduction in } \\
\text { growth }\end{array}$ \\
\hline Soils/sediments & Heavy metals, organics & Contamination of soils and sediments \\
\hline \multirow[t]{3}{*}{ Aquatic systems } & $\begin{array}{l}\mathrm{SO}_{2}, \mathrm{NO}_{x}, \text { and their acidic } \\
\text { products }\end{array}$ & $\begin{array}{l}\text { Acidification of waters with subsequent } \\
\text { damage to aquatic ecosystems through } \\
\text { reduction in species diversity, changes in } \\
\text { feeding dynamics, chemical and ionic } \\
\text { imbalances, reproductive abnormalities, } \\
\text { and accumulation of toxic substances }\end{array}$ \\
\hline & Heavy metals, organics & $\begin{array}{l}\text { Damage to a quatic organisms, } \\
\text { bioaccumulation in the food chain }\end{array}$ \\
\hline & $\begin{array}{l}\text { Phosphorus, nitrogen, and } \\
\text { other nutrients }\end{array}$ & Eutrophication \\
\hline Marine organisms & Heavy metals, organics & $\begin{array}{l}\text { Accumulation of toxic substances in } \\
\text { shellfish and other sea organisms, red } \\
\text { tides, changes in predator-prey } \\
\text { relationships }\end{array}$ \\
\hline \multirow[t]{6}{*}{ Materials and structures } & $\mathrm{SO}_{2}$ & $\begin{array}{l}\text { Corrosion of metals, discoloration of mortar } \\
\text { and brick, weakening of fabrics }\end{array}$ \\
\hline & $\mathrm{O}_{3}$ & $\begin{array}{l}\text { Weakening and cracking of rubber, damage } \\
\text { to asphalt }\end{array}$ \\
\hline & $\begin{array}{l}\mathrm{SO}_{2} \text { and } \mathrm{NO}_{x} \text { and their } \\
\text { acidic products }\end{array}$ & $\begin{array}{l}\text { Leaching and weakening of brick and } \\
\text { mortar, corrosion of metals, surface } \\
\text { degradation of glass }\end{array}$ \\
\hline & Particulates & $\begin{array}{l}\text { Soiling of surfaces, increased resistance of } \\
\text { electricál contacts }\end{array}$ \\
\hline & $\mathrm{NO}_{2}$ & Fading of textile dyes \\
\hline & Fluoride & Damage to glass \\
\hline
\end{tabular}


TABLE 7 (Cont.)

\begin{tabular}{|c|c|c|}
\hline Resource & Pollutant & Effect \\
\hline \multirow[t]{3}{*}{ Atmospheric properties } & $\mathrm{NO}_{2}$ & $\begin{array}{l}\text { Discoloration of the horizon, production of } \\
\text { haze }\end{array}$ \\
\hline & $\begin{array}{l}\mathrm{SO}_{2}, \text { particulates, and } \\
\text { aerosols }\end{array}$ & Decrease in visibility \\
\hline & $\begin{array}{l}\mathrm{CO}_{2} \text { and other greenhouse } \\
\text { gases, aerosols, particulates }\end{array}$ & Climate changes \\
\hline \multirow[t]{8}{*}{ Human health } & $\mathrm{SO}_{2}$ & $\begin{array}{l}\text { Odor, increased airway resistance, } \\
\text { impairment of lung function, asthmatic } \\
\text { attacks }\end{array}$ \\
\hline & $\begin{array}{l}\mathrm{NO}_{x} \text {, hydrocarbons, ozone, } \\
\text { peroxyacyl nitrate }\end{array}$ & $\begin{array}{l}\text { Respiratory and eye irritation, coughing, } \\
\text { headache, pulmonary edema }\end{array}$ \\
\hline & $\mathrm{CO}$ & $\begin{array}{l}\text { Cardiovascular and central nervous system } \\
\text { dysfunction }\end{array}$ \\
\hline & Benzene & Leukemia \\
\hline & Particulates & $\begin{array}{l}\text { Lung fibrosis (especially from asbestos), } \\
\text { lung cancer, liver and kidney damage, } \\
\text { central nervous system dysfunction } \\
\text { (especially from lead) }\end{array}$ \\
\hline & Mercury & $\begin{array}{l}\text { Tremors, behavioral disturbances, renal } \\
\text { toxicity }\end{array}$ \\
\hline & Organics, heavy metals & $\begin{array}{l}\text { General toxicity, central nervous system } \\
\text { dysfunction, renal disturbances, } \\
\text { reproductive impacts }\end{array}$ \\
\hline & Pathogens & Infectious diseases \\
\hline
\end{tabular}

\subsubsection{Health Impacts}

Health impacts are usually of paramount concern when the effects of various anthropogenic processes and activities are being assessed. Pollutants discharged into any medium can lead to deterioration of human health. Emissions of pollutants such as $\mathrm{SO}_{2}$, hydrocarbons, VOCs, particulates, toxic substances, lead, and $\mathrm{CO}$ into the air can lead to degradation of both indoor and outdoor air quality. The discharge of toxic substances into water systems can result in contamination of drinking water supplies. The release and accumulation of hazardous chemicals in soil systems can lead to contamination of food and leaching of contaminants into groundwater and surface waters. In addition, changes in climatic patterns can exacerbate the health-related impacts of many pollutants as well as result in new dangers to human health. 
In China, the large population base, heavy industrialization, and high energy demand have increased the potential for large-scale contamination of air, water, and soil systems. In addition, because the activities and processes that can damage human health are usually located close to large population centers, the likelihood of risk to the human population is high.

Environmental contamination and alteration can have a wide variety of effects on humans. Some of the most important ones are discussed below.

The predominant cause of death in China is respiratory disease; it accounted for $26 \%$ of all deaths in the country in 1988 (Florig 1993). The incidence of lung cancer is also high in China, with more cases observed in women than in men. (Indoor air quality likely plays an important role in the etiology of lung cancer, since women spend more time indoors than do men. This statistic also downplays the role of smoking, since men are heavier smokers than women in China.) The incidence of lung cancer also follows a north-south gradient in China, which coincides with the quality of the heating fuel (predominantly coal) used in various parts of the country. This gradient also correlates with total suspended particulate (TSP) concentrations, which are much higher in the northern portions of the country than the southern parts. The TSP found in China often contains carcinogenic substances such as benzene, benzo(a)pyrene, cadmium, nickel, and arsenic. Thus, air pollution, both indoor and outdoor, likely plays a significant role in contributing to respiratory ailments common in China.

Contamination of water resources also poses risks to human health in China. Most wastewater is discharged untreated into waterways, and this unpurified water is often used for bathing, drinking, and cooking. It is estimated that less than $15 \%$ of the population in China has access to safe drinking water supplies (Shanley 1995). Seven of the major rivers in China are so polluted that they render no potable water at all (WER 1995b). Water shortages are also common in this country. Acid rain has recently become a problem in some parts of China; it can lead to acidification of surface waters, with the resultant leaching of metals into water supply systems. In coastal areas, where much of the population depends on seafood for its protein supply, pollution of offshore waters has caused declines in seafood harvests and an accumulation of toxic chemicals in organisms that are caught and eaten. Together, air and water pollution are thought to be responsible for the high rates of hepatitis and cancer of the stomach, liver, and intestines that are prevalent in China.

It is also probable that changes in global and regional climate patterns could pose a risk to human health in China. Higher temperatures could increase reaction rates of contaminants in the atmosphere, leading to a worsening of air quality. In addition, changes in climate could result in the increased prevalence of exotic diseases and new disease vectors to which indigenous populations have little resistance. Changes in agricultural crop zones due to alterations in rainfall and temperature patterns could lead to crop failures and food shortages. Water supplies could also be affected by climatic changes, with lower water levels in some waterways leading to increases in pollutant 
concentrations and with increased water flows in other waterways resulting in flooding and the spreading of waterborne diseases. Inundation of coastal areas and infiltration of saltwater into the groundwater due to sea level rise would also threaten human health. Such conditions would exacerbate the water shortage and overcrowding problems currently existing in China.

\subsubsection{Other Impacts}

As shown in Table 7, impacts to other components of the environment caused by anthropogenic activities and processes are also of concern in China. One of the most significant components in terms of societal concern is the agricultural sector.

\subsubsection{Agriculture}

Agricultural systems can be affected by a wide variety of activities and processes. The major activities and the related pollutants that threaten agricultural production are the following:

- High ambient concentrations of $\mathrm{SO}_{2}$ and tropospheric ozone, mainly from energy and industrial activities;

- Water and soil contamination from industrial, agricultural, and mining activities;

- Atmospheric particulates generated through combustion, mining, construction, and transportation activities;

- Soil degradation (e.g., erosion, compaction) resulting from industrial, construction, land use changes, and mining activities; and

- Soil degradation caused by salinization of irrigated agricultural land.

Activities that lead to soil contamination, particularly the discharge of toxic chemicals and organic wastes, can also impair crop growth. In addition, activities that lead to soil degradation (erosion, salinization) can reduce agricultural productivity as a result of the loss of topsoil and soil nutrients, which decreases the biological and economic productivity of the land. It has been estimated that almost $20 \%$ of the 100 million hectares of arable land in China is affected by some degree of salinization; in northern China alone, 7.7 million hectares are salinized (Jinfa 1994). In southern China, where rainfall rates are high and the natural vegetation on hillsides has been removed, water erosion is severe. Approximately 48 million hectares in the 11 provinces of southern China are affected by water erosion. With the increased economic activity in China over the past few decades, erosion rates have increased by 1.5 to 4.7 times in southern China (Jinfa 1994). Grain 
production in severely eroded areas is $10-50 \%$ less than the regional average for this part of the country (Jinfa 1994).

In addition, deposition of acidic compounds onto plants and soils and the presence of other air pollutants such as ozone and/or $\mathrm{SO}_{2}$ can threaten agricultural plants. These pollutants, because of their propensity for long-range transport, have the potential to affect crop growth far from the point at which they are emitted. The prevailing monsoon winds during the crop-growing season (summer) carry pollutants from urban centers in eastern China into the more agricultural provinces to the west (Bhatti et al. 1992). To illustrate, rainfall with a pH as low as 2.25 (normal range is 5.67.0) has been observed in the remote Tibetan plateau of Qinghai province (Harte 1983). Because it has been found that rice and wheat, which are staple crops in China, are sensitive to rain with a $\mathrm{pH}$ of less than 4.5 (Zhao and Xiong 1988), these crops would be significantly affected in regions downwind of emission sources for acid precursor pollutants.

Climatic changes are also likely to play a significant role in crop production in the future. Increased temperature may result in a shift from single- to double-cropping systems and from double- to triple-cropping systems in some areas. Although such shifts could potentially increase agricultural yields, these increases would be dependent on an adequate supply of water and soil nutrients. Adequate water supplies may not be available, because even in the presence of increased precipitation, higher temperatures would increase evapotranspiration rates and dry up current water reservoirs. Soils nutrients would also be limited because of the increased intensity and frequency of storms, which would lead to greater soil erosion with an accompanying depletion of soil nutrients. Changes in climatic conditions would also alter the optimum range for growing species crops. To continue to grow certain crops under these altered conditions would require greater inputs of energy and water resources. It has been estimated that a $1-2^{\circ} \mathrm{C}$ rise in temperature would reduce agricultural production in China by 5\% (WuDunn 1993; Wilson 1993). Sea level rise and saltwater intrusion of aquifers due to climate change would further increase land use pressures and reduce irrigation water supplies. In addition, changes in climatic conditions would alter disease and pest vectors that could threaten crops, especially monoculture crops that have little resistance to exotic diseases and pests.

\subsubsection{Aquatic Resources}

Aquatic resources have also been severely impacted by anthropogenic activities and processes that are prevalent in China. The discharge of contaminants, especially heavy metals and organics, into waterways can result in significant damage to aquatic organisms. Many of these pollutants (such as mercury and cadmium) can bioaccumulate in the food chain, causing serious consequences to predators high on the food chain, such as birds and mammals, including humans. Agricultural activities, especially the heavy application of fertilizers and nutrients, can result in eutrophication of water systems. Mining and other industrial activities can lead to siltation of water systems as well as contamination of the water contained in these systems. Acidic substances released 
from mining sites or deposited via precipitation can acidify water systems, causing subsequent damage to aquatic organisms. Such damage can occur both through direct toxic effects of acidic substances on the chemical and ionic balances of these organisms and through indirect impacts, such as the accumulation of toxic compounds in the water. Erosion of agricultural and built-up lands can increase sedimentation of water systems, thus reducing navigability and increasing the danger of flooding. The Huanh He (Yellow) River is the most silt-laden river in the world. It carries 1 billion tons of sediment per year, which is mainly a result of soil erosion caused by deforestation activities in the highlands (WRI 1992).

Climatic changes would also probably have serious consequences on the health of aquatic resources. Changes in temperature and precipitation patterns could affect both the quantity and quality of water systems. Higher temperatures would increase evaporation rates from water bodies, thereby lowering water levels and increasing the concentration of pollutants in these systems. If such an increase in temperature were to be accompanied by an increase in precipitation, these impacts might be mitigated to some extent, but it is unlikely that increases in precipitation would be adequate enough or occur at the proper time or in the right fashion to replenish the increased demand on water systems likely to result from higher temperatures.

\subsubsection{Marine Resources}

Marine resources are also affected by anthropogenic activities and processes. Much of the pollution produced in the highly industrialized and populated coastal regions is discharged directly into the ocean after receiving little or no treatment. Thus, coastal waters often contain high levels of heavy metals, hazardous chemicals, radioactive substances, nitrates, organic compounds, and pathogenic organisms. This discharge can lead to the bioaccumulation of toxic substances in shellfish and other marine organisms, frequent occurrence of red tides, and reduction in the harvest of marine organisms. In addition, the increased incidence and severity of coastal storms due to climatic changes would physically damage marine organisms. Increased sediment loads of rivers emptying into the ocean would result in siltation and inundation of spawning grounds, thereby further reducing the number of marine organisms.

\subsubsection{Forests}

Anthropogenic activities and processes can also have considerable impacts on forest resources in China. Land use changes, timber harvesting, and deforestation are currently the greatest threats to forest ecosystems. At the present time, annual cutting surpasses new growth by $44 \%$ in spite of tree planting campaigns introduced by the government (WRI 1992). Because of this rapid deforestation rate, $45 \%$ of the highlands in China suffer severe soil erosion (WRI 1992). The second greatest threat to forest ecosystems at the current time is air pollution. Tropospheric ozone has been 
shown to damage many tree species, especially pines, which make up a considerable portion of the forests in China. In addition, because trees are a long-lived species, cumulative effects of pollutants such as $\mathrm{SO}_{2}, \mathrm{NO}_{\mathrm{x}}$, and ozone, even at relatively low ambient concentrations, can have significant impacts on forest ecosystems. Acid deposition is also a threat to forest species in China and is likely to pose a greater risk in the near future. Both ozone and acid deposition, because of their propensity for long-range transport and the fact that they are secondary pollutants, can affect forest ecosystems hundreds of miles away from the point at which the precursors to these pollutants are emitted. Because of the nature of the prevailing winds in China, forests in the northeastern part of the country are likely to be at greatest risk from these regional pollutants (Bhatti et al. 1992).

Soil degradation (e.g., erosion, compaction) and contamination, especially from the heavy metals caused by mining and industrial activities and from the application of pesticides and herbicides in agriculture, can also damage forest ecosystems. Such damage occurs closer to the source of the degradation and contamination activities.

Climate change is likely to play a dominant role in affecting forest ecosystems in the future. Changes in temperature and precipitation would significantly alter the distribution of natural vegetation zones in China. Forests currently at the extremes of their natural ranges would be most severely affected by such changes. Such forests include the temperate coniferous forests of the northeast and the warm temperate deciduous forests of the central coastal regions. Many of these forests could be converted to shrubland or grassland. In addition, loss of land along the coasts as a result of sea level rise and intrusion of saltwater into aquifers would further increase the land use pressures on remaining forest stands. Also, changes in climatic conditions would alter the distribution of forest pest and disease vectors, which could result in damage to tree species that have little resistance to these "new" organisms.

\subsubsection{Visibility}

Visibility can also be affected by anthropogenic activities and processes, especially those that produce emissions of particulates, ozone precursors, $\mathrm{SO}_{2}$, and $\mathrm{NO}_{\mathrm{x}}$. In many parts of China, visibility is severely limited for many days of the year. In Benxi, industrial smog limits visibility to 40-50 yards for six months of the year (WRI 1992). Climatic changes would exacerbate these effects, as higher temperatures would increase reaction rates of processes that transform emitted substances into visibility-impairing substances.

\subsubsection{Other Sectors}

Man-made resources such as buildings and the transportation infrastructure can also be affected by anthropogenic activities. Those structures located in areas with high ambient 
concentrations of air pollutants are especially affected. High levels of $\mathrm{SO}_{2}$, acidic gases, oxidants and ozone, and particulates can damage stone, masonry, cement, paints, metals, rubber, textiles, and ceramics (Robinson 1977). News reports have indicated that centuries-old Buddhist temples and figurines in Shanxi Province are being destroyed as a result of industrial pollutants in the region (WER 1995a). Such damage by air pollutants could be exacerbated by climatic changes, particularly if these changes were to include higher temperatures (which would increase the reaction rates of the damaging substances) and greater storm intensity and frequency (which would accelerate the physical erosion of materials). In addition, increased storm frequency, with its attendant surges in water levels in inland rivers and lakes as well as sea level rise, would threaten dams, dikes, levees, and sea walls. Structures located in permafrost zones would also be susceptible to damage from climate changes, because increased temperatures would reduce or eliminate the permafrost layer and cause the collapse of structures built on such layers.

\subsection{LOCATION OF SENSITIVE RECEPTORS}

As was made evident in the last section, a variety of receptors, both natural and anthropogenic, could be sensitive to the variety of pollutants emitted and discharged into the air, water, soils, and sediments in China. However, to actually be affected by these contaminants, the sensitive receptors must be in contact with the pollutants of concern. The location of these receptors relative to the source of the pollutant to which they are sensitive must be evaluated to determine if there is a potential for damage to such receptors.

In some cases, these receptors are scattered throughout most of the country. Usually, however, the general location of these receptors can be determined. The overall location of the major, sensitive receptors are listed in Table 8. In many cases, the most severe effects are likely to be felt in the following areas and/or situations:

- Marginal areas, such as those currently experiencing severe water deficiencies;

- Resources at the extreme limits of their natural ranges;

- Populations and resources in coastal and low-lying regions;

- Structures in permafrost zones;

- Populations in urban areas (which are already stressed by overcrowding and high pollutant loading); and

- Populations and resources downwind and downstream of industrial and agricultural centers. 
TABLE 8 General Location of Receptors at Risk to Various Pollutants in China

\begin{tabular}{ll}
\hline \multicolumn{1}{c}{ Receptor } & \multicolumn{1}{c}{ General Location } \\
\hline Human populations & $\begin{array}{l}\text { Concentrated in crescent-shaped region along coast from Shenyang } \\
\text { to Hong Kong, other urban centers }\end{array}$ \\
Forests & Northeast China, western China \\
Crops & Eastern and southern coastal areas, eastern plains \\
Materials, structures & Urban areas \\
Aquatic resources & In and around major rivers, western China (Tibet) \\
Marine resources & Along coastal areas \\
\hline
\end{tabular}

In general, the resources and populations at highest risk from damage caused by anthropogenic activities and processes in China are those located in the crescent-shaped region shown in Figure 1, other coastal areas, the Tibetan plateau, and the northeastern forest region. 


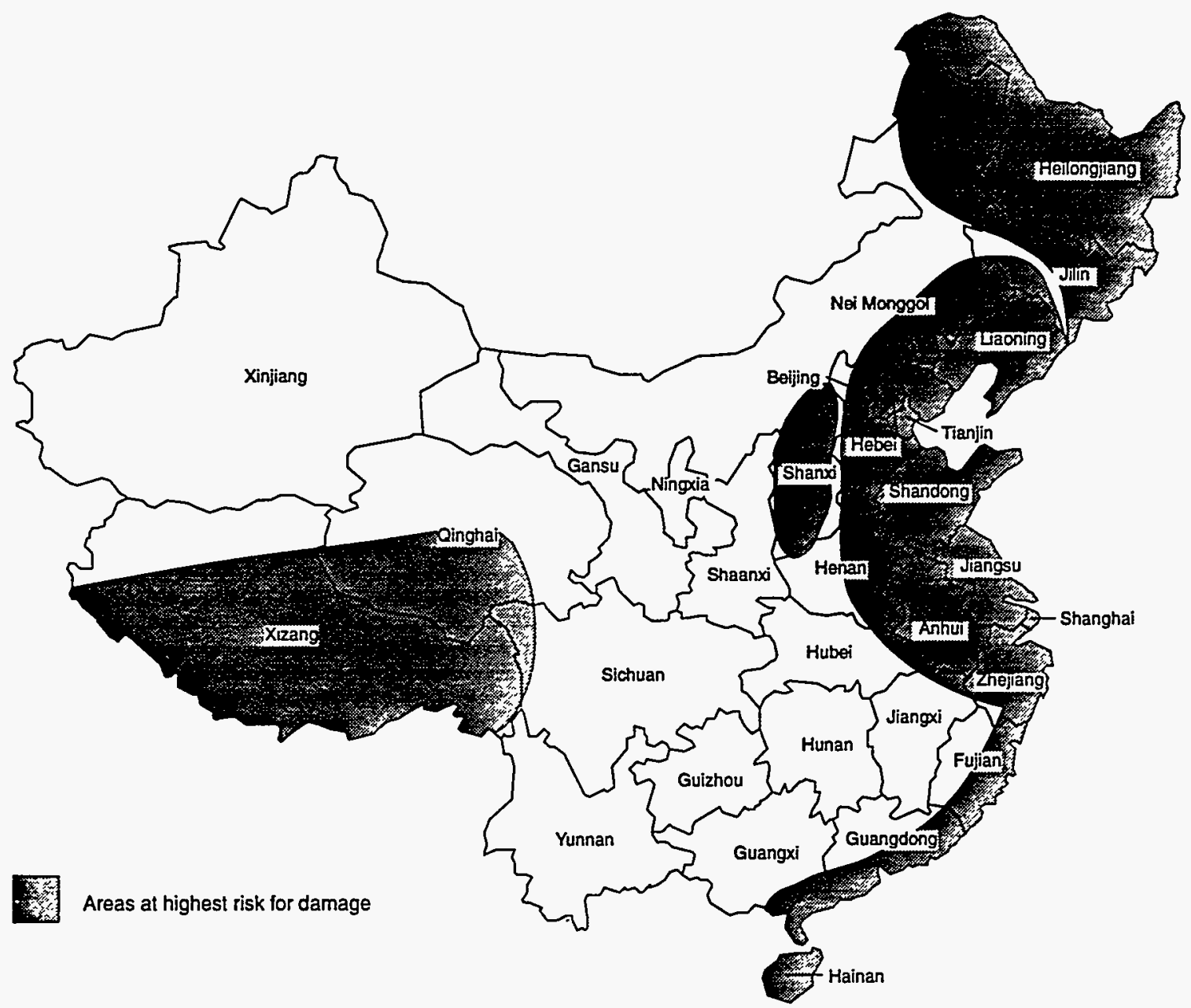

FIGURE 1 Areas at Highest Risk from Damage Caused by Anthropogenic Activities and Processes in China 


\section{REGULATORY/AMELIORATIVE OPTIONS FOR CHINA}

The discussion in Section 2 reveals that China is currently experiencing some very severe environmental impacts related to its industrial, agricultural, and other anthropogenic activities. As China continues to pursue rapid economic reform and development and as its population continues to grow, it is very probable that these impacts will become even more severe. In light of this

situation, it is imperative that China adopt some form of environmental controls on its anthropogenic activities and processes.

\subsection{HISTORY OF ENVIRONMENTAL REGULATIONS IN CHINA}

Since 1949, the primary emphasis of government policies has been on meeting planned industrial production goals. Only recently have the environmental implications of industrial development been considered in Chinese planning and regulatory policies, and this consideration has been at only a very rudimentary level. However, the Chinese government is becoming increasingly aware that many of the activities and processes it encourages have social and economic costs. The rapid deterioration of air quality in urban areas, depletion and contamination of drinking water reserves, shortage of water for irrigation and industrial use, desertification and degradation of arable land, contamination of surface water systems and coastal seas, loss of forest and natural ecosystems, and reduction of biodiversity have alerted both the government and the public that some action must be taken if China is to remain a healthy and economically viable country.

Some regulatory measures have already been introduced in China in an attempt to address the environmental threats facing the country. (Some of this discussion of the history of environmental regulations in China is derived from Bhatti et al. 1994.) One of the earliest environmental programs implemented in China was designed to combat desertification. This effort was begun in 1978 and involved the planting of a shelterbelt of trees (known as the Great Green Wall of China). This program is expected to eventually cover 5.3 million acres with trees (WRI 1992). In 1979, China passed the Law of Environmental Protection and created the Environmental Protection Commission (EPC). However, it was not until 1988 that the EPC's executive body, the National Environmental Protection Agency (NEPA), and the provincial Environmental Protection Bureaus (EPBs) were formed to formulate and implement environmental regulations. The EPBs are responsible for enforcing the standards set by NEPA, monitoring the discharge of pollutants into the air and water, collecting discharge fees and punitive fines from polluters, and conducting environmental impact assessments. In 1989, China passed the 1989 Environmental Protection Law, which clarified the responsibility of NEPA and the EPBs. Environmental issues are covered in the Chinese Agenda 21, which was approved in 1994. Combatting desertification and reversing land degradation is listed as Chapter 16 of the Agenda 21 document. In addition, the Chinese government has allocated \$23 billion for environmental programs over the six years from 1995 through 2000. 
The majority of this money is to be spent on pollution remediation and abatement of industrial effluents (WER 1994a). The Chinese government has also established 179 protected areas covering approximately 20 million acres (less than $1 \%$ of the country) (WRI 1992). As part of this effort, China has begun a three-year project to control pollution of the Huaihe River. Currently, about 1,000 institutions dump $6.5 \times 10^{6} \mathrm{t}$ of untreated industrial and municipal wastewater each day into this river, which runs through eastern China. This project will require all businesses along the river to treat their wastes before releasing them into the river by 1997 or risk being shut down (WER 1994b).

In 1995, the Chinese government increased its emphasis on environmental concerns by integrating these concerns into the 1996-2000 five-year plan. This plan involves a commitment to improving living standards by strengthening environmental protection activities, particularly through increased enforcement of environmental laws (WER 1995b).

In spite of these efforts to combat environmental degradation, there are significant obstacles to the implementation of environmental regulations in China. These obstacles include, in part, the lack of public support for and understanding of such laws, overriding priority given to economic development, setting of pollution fees and fines well below the cost of treating these wastes, and subsidized prices for coal, water, and other national resources that encourage overuse and waste. Because of the high rate of industrialization and the lack of enforcement of environmental regulations, more cities in China than any other country exceed the World Health Organization (WHO) guidelines for air pollution.

In part because of the poor air quality in urban areas, the priority of recent environmental regulations in China has been to address the problem of air pollution - and urban air pollution in particular. Since coal combustion activities are a major cause of this air quality degradation in urban areas, the main targets of China's environmental policies are to prevent and control atmospheric effluents caused by coal combustion and to increase the efficiency of coal use. Ambient air quality standards are in effect in China for $\mathrm{SO}_{2}$, particulates, and $\mathrm{NO}_{\mathrm{x}}$. These standards are listed in Table 9, with U.S. standards and WHO guidelines provided for comparison.

It appears that China has implemented air quality standards that are comparable to the U.S. and WHO standards for $\mathrm{SO}_{2}$, particulates, and $\mathrm{NO}_{\mathrm{x}}$. In fact, in some cases, the Chinese standards are even more stringent than those of the United States. However, enforcement of these standards has not been actively pursued to date, as evidenced by the frequent, almost daily, violations of these standards in most urban areas in China.

Controls on the release of wastewater and the dumping of solid wastes are even more lax in China than is control of air pollutants. Thus, it is evident that China needs to overhaul its current environmental regulations and to implement and enforce more stringent controls on the release of pollutants into the air, land, and water systems if it is to improve the condition of its environment and the health of its people. Such improvements can occur through the implementation of a number 
TABLE 9 Ambient Air Quality Standards

\begin{tabular}{cccccc}
\hline & & \multicolumn{4}{c}{ Maximum Allowable Concentration $\left(\mu \mathrm{g} / \mathrm{m}^{3}\right)$} \\
\cline { 3 - 6 } Pollutant & $\begin{array}{c}\text { Averaging } \\
\text { Period }\end{array}$ & $\begin{array}{c}\text { China } \\
\text { Primary }\end{array}$ & $\begin{array}{c}\text { China } \\
\text { Secondary }\end{array}$ & U.S. Primary & WHO Guidelines \\
\hline \multirow{2}{*}{$\mathrm{SO}_{2}$} & Yearly & 20.0 & 60.0 & 80.0 & $40-60$ \\
& Daily & 50.0 & 150.0 & 365.0 & \\
\multirow{2}{*}{$\mathrm{TSP}$} & Daily & 150.0 & 300.0 & 75.0 (annual) & $60-90$ (annual) \\
& & & & 150.0 (for PM & \\
& & & & 100.0 (annual) & 150.0 (24 hours) \\
\hline
\end{tabular}

Source: Adapted from Zhao and Sun (1986); UNEP/WHO (1994).

of strategies, ranging from minor changes in current environmental regulations to adoption of standards and regulations comparable to those of the United States, Canada, and/or western Europe. In March 1994, the Chinese government announced plans to strengthen its environmental regulations by making them more comprehensive and implementing stronger enforcement provisions. These new regulations are to take effect in 1996 (Shanley 1995).

However, given China's economic situation and its emphasis on economic development, it is highly unlikely that environmental regulations comparable to those in the West will be adopted and implemented anytime soon. Thus, the near-term objective of any policy to begin cleaning China's environment must be based on reasonable and economically feasible strategies that have benefits in addition to reducing pollutant loading. Such a policy must also focus on alleviating the most pressing environmental needs that the country currently faces.

\subsection{MAJOR ENVIRONMENTAL THREATS CURRENTLY FACING CHINA}

The most immediate environmental problems in China at present are:

- Urban air pollution, particularly the high ambient levels of $\mathrm{SO}_{2}, \mathrm{NO}_{\mathrm{x}}$, and particulates;

- Waterborne diseases in lakes, rivers, streams, and coastal areas; 
- Chemical contamination of groundwater and surface waters;

- Sediment loading of water systems;

- Water shortages; and

- Soil degradation.

At a minimum, it would appear that China should address these immediate problems. The roots of these threats depend on the particular problem and thus require different control strategies. The main sources of the problems above are listed in Table 10.

All of these problems are those first experienced by a country as it proceeds along an increasingly industrialized path. In fact, the air and water quality problems currently facing China are remarkably similar to those experienced by the United States in the early 1940s. Thus, it is likely that China could profit from the U.S. experience and use some of the same strategies that were effective in alleviating the air and water pollution problems in the United States in the early 1950s or so.

\subsection{EARLY U.S. EXPERIENCE IN ADDRESSING POLLUTION PROBLEMS}

\subsubsection{Air}

The awareness in the United States of the seriousness of air pollution was a consequence of a series of acute episodes of air pollution that occurred in both western Europe and the United States from the 1930s through the early 1950s. These air pollution disasters included those that occurred in the Meuse Valley, Belgium; London, England; Donora, Pennsylvania; New York City, New York; and Los Angeles, California. The levels of air pollution that were measured during some of these episodes are listed in Table 11. Maximum levels of these air pollutants that currently have been observed in Chinese cities are provided for comparison.

In reaction to the Meuse Valley air pollution disaster of 1930, in 1936, the U.S. Public Health Service initiated a research program to study the extent and quality of air pollutants in 14 major U.S. cities. After the Pennsylvania, New York, and Los Angeles air pollution episodes, the United States signed the Air Pollution Control Act into law in 1955. This act emphasized the central role of the states and municipalities in establishing and enforcing air quality standards. The federal government's role was restricted to providing research funds for the coordination of air pollution control options. The Clean Air Act (CAA) of 1963 set up criteria for federal enforcement and encouraged uniform state laws. The initial method for dealing with high concentrations of certain 
TABLE 10 Environmental Threats and Their Sources

Air quality

$\mathrm{SO}_{2}$

Electric utilities

Industrial and residential boilers

Petrochemical industries

Smelters

Iron and steel manufacturing

$\mathrm{NO}_{\mathrm{x}}$

Electric utilities

Residential and industrial boilers

Smelters

Fuelwood burning

Iron and steel manufacturing

Incinerators

Motor vehicles

Particulates

Electric utilities

Cement manufacturing

Residential and utility boilers

Construction activities

Fuelwood buming

Motor vehicles

Iron and steel manufacturing

Incinerators

Ozone

Motor vehicles

Wood burning

Water quality

Disease organisms

Untreated sewage

Human and animal wastes

Wastewater effluents

Chemical pollutants (heavy metals,

Electric utilities pesticides/herbicides, nutrients, Industrial processes sediments)

Wastewater treatment effluents

Forestry practices

Agriculture

Construction

Pulp and paper mills 
TABLE 10 (Cont.)

\begin{tabular}{|c|c|}
\hline Problem/Pollutant & Main Source \\
\hline \multicolumn{2}{|l|}{ Water quality (Cont.) } \\
\hline Sediment loading & $\begin{array}{l}\text { Agricultural activities } \\
\text { Deforestation } \\
\text { Construction } \\
\text { Land use changes }\end{array}$ \\
\hline Water shortages & $\begin{array}{l}\text { Consumption by industry, agriculture, } \\
\text { and human populations } \\
\text { Pollution of water systems }\end{array}$ \\
\hline Soil degradation & $\begin{array}{l}\text { Industrial activities } \\
\text { Agricultural practices } \\
\text { Land use changes } \\
\text { Construction activities } \\
\text { Deforestation }\end{array}$ \\
\hline
\end{tabular}

TABLE 11 Air Pollution Levels during Acute Episodes in Various Cities and Current Levels in Beijing

\begin{tabular}{llrr}
\hline & & \multicolumn{2}{c}{ Pollutant Level } \\
\cline { 3 - 4 } \multicolumn{1}{c}{ Location } & \multicolumn{1}{c}{ Date } & $\mathrm{SO}_{2}\left(\mu \mathrm{g} / \mathrm{m}^{3}\right)$ & $\begin{array}{c}\text { Particulates } \\
\left(\mu \mathrm{g} / \mathrm{m}^{3}\right)\end{array}$ \\
\hline Meuse Valley, Belgium & Dec. 1-5, 1930 & $25,000-100,000$ & \\
Donora, Pennsylvania & Oct. 26-30, 1948 & $1,400-5,500$ & \\
London, England & Dec. 5-9, 1952 & 3,750 & 4,460 \\
Beijing, China & 1990 maximum & 682 & 1,286 \\
& levels & & \\
\hline
\end{tabular}

Sources: UNEP (1993); Dworsky (1971); Miller (1982). 
air pollutants (i.e., $\mathrm{SO}_{2}$ and particulates) was to build tall smokestacks on large pollution sources to disperse these pollutants. This solution alleviated the high pollutant levels in the areas immediately surrounding these sources but increased concentrations downwind from these emitters and resulted in the formation of regional air pollutants such as acid rain and ozone.

The CAA of 1963 was amended in 1967 with the request that states adopt air quality standards and designate air quality control regions. Even with these amendments, there were still no national air pollution standards, and standards varied significantly from state to state. In addition, there were no provisions for effective federal enforcement of these standards. The CAA of 1970 addressed these flaws and introduced the command and control approach to air pollution control. National air quality standards were established, and states were required to develop implementation plans to meet these standards. These implementation plans were to be based on emission limits set for individual sources or source categories. The $1970 \mathrm{CAA}$ also contained deadlines and strengthened enforcement. The major pollutants for which national air quality standards were established were $\mathrm{SO}_{2}, \mathrm{NO}_{\mathrm{x}}, \mathrm{CO}$, particulates, ozone, and hydrocarbons. Lead was added in 1977 when the CAA was amended again. The main change to the CAA in 1977 involved the imposition of new requirements on clean areas that were already in attainment of standards. The requirements were carried out under the prevention of significant deterioration (PSD) program.

The most sweeping changes to the CAA were implemented through the amendments to the CAA enacted in 1990. These included a more detailed and graduated program for areas not inattainment and a revision of the air toxics section of the CAA, so it now established a list of 189 regulated hazardous air pollutants. The biggest regulatory change to the CAA was the new permit program, which mirrors the requirements set out in the Clean Water Act. This change requires all major sources to obtain an operating permit. The CAA amendments of 1990 also contained a more stringent provision for controlling the threat of acid rain, with a nationwide limit imposed on $\mathrm{SO}_{2}$ emissions. This provision is to be carried through the sale and purchase of emission allowances on the open market. The $1990 \mathrm{CAA}$ amendments also strengthened the enforcement powers of the U.S. Environmental Protection Agency (EPA) and regulated a greater number of sources and smaller sources than had been regulated before.

\subsubsection{Water}

\subsubsection{Clean Water Act}

The beginning of the Clean Water Act dates back to 1948, when public concern for bacterial contamination of drinking water led to federal programs to assist states in constructing and operating wastewater treatment plants. The 1948 law contained no federal requirements with regard to the 
control of water pollution. It was limited to protecting the primary responsibility of the states to control water pollution (BNA 1991).

Under the Water Quality Act of 1965, the federal government began to help states and interstate compact organizations establish and enforce water quality standards to protect surface water. Generally, the standards developed under this statute were intended to be used to formulate individualized permit limitations for each discharger. The program had no provision for direct enforcement of the limits established by the act and proved to be impractical for a number of reasons (Government Institutes, Inc. 1993).

In late 1972, Congress passed the Federal Water Pollution Control Act. This act required all municipal and industrial wastewater to be treated before it could be discharged into waterways. It required the EPA to set technology- and cost-based effluent standards to be applied nationwide on an industry-by-industry basis. The limits were to be written into national pollutant discharge elimination system (NPDES) permits issued to all dischargers. The law also defined water quality standards, contained special provisions for oil spills and toxic substances, and provided for a grant program to construct publicly owned treatment works (POTWs). With some modification, these features have been successful and are currently in effect today (Government Institutes, Inc. 1993).

The Clean Water Act of 1977 covered enforcement against toxic dischargers. By 1987, the act was again amended to direct the EPA and the states to supplement existing technology-based standards with a water-quality-based approach to control persistent pollution problems (Government Institutes, Inc. 1993).

Other provisions of the amendments built on and strengthened an existing program to improve the quality of lakes, require permits for discharges of storm water, promulgate regulations to control toxic pollutants in sewage sludge, and specify deadlines for issuance of industrial effluent limitations. The 1984 drinking water quality guidelines developed by the WHO are provided in Appendix A with the U.S. water quality criteria for selected years between 1972 and 1994.

\subsubsection{Safe Drinking Water Act}

The Safe Drinking Water Act (SDWA) was enacted in 1974, assigning responsibility for its administration to the EPA. The goal of the SDWA is to ensure that drinking water is suitable to drink. It requires the EPA to set national drinking water standards that must be met by the supplier. The SDWA also provides for protection of groundwater, which serves as the principal source of drinking water for the majority of the population in the United States. It allows the EPA to protect aquifers that constitute the principal source of drinking water for particular areas by designating them as sole source aquifers (BNA 1991). 
National drinking water standards established under the SDWA apply only to public water systems that provide piped water for human consumption. The definition of water consumption includes drinking, bathing, cooking, dishwashing, and maintaining oral hygiene (Goverment Institutes, Inc. 1993).

In 1975, the EPA designated two types of public water systems (PWSs) - community and noncommunity. Community systems regularly serve at least 25 year-round residents. Noncommunity systems are all other systems that otherwise meet the definition of a PWS. This designation was made so that drinking water standards designed to protect against the adverse effects of long-term or chronic exposure would apply to only those systems whose users would drink the water over long periods of time (i.e., systems serving residential populations) (BNA 1991). The 1976 published surface water quality limits for a public water supply are provided in Appendix B.

In 1987, it was recognized that persons served by noncommunity systems were receiving long-term exposure to contaminants in drinking water. These persons included people in schools, factories, and offices with private water supply systems. Regulations were amended to include a new type of PWS - the nontransient, noncommunity water system (four days per week for at least 26 weeks per year (Government Institutes, Inc. 1993).

The SDWA authorizes the EPA to establish two types of national drinking water standards: national primary drinking water regulations and national secondary drinking water regulations. The primary standards are meant to protect against any adverse effects to health from the consumption of drinking water. The secondary standards are meant to protect the aesthetic qualities of drinking water, (i.e., odor and appearance) and are not enforceable (Government Institutes, Inc. 1993).

In June 1989, the EPA published a combined filtration and disinfection rule that specifies when these treatment techniques must be used by PWSs that draw their water from surface waters (or from groundwater under the direct influence of surface water). The filtration rule is unusual in that it requires states to make a case-by-case determination about which of their systems must filter water (Government Institutes, Inc. 1993).

Primary drinking water standards are set in a two-step process. First, the EPA determines a maximum contaminant level goal (MCLG). By statute, the MCLG must be set at a level at which no known or anticipated adverse effects on the health of persons occur and a level that allows an adequate margin of safety. MCLGs are not enforceable (Government Institutes, Inc. 1993).

For noncarcinogens, the MCLG is based on the reference dose (RfD). The RfD is an estimate, with uncertainty spanning perhaps an order of magnitude, of the daily exposure to the human population that is likely to be without an appreciable risk of deleterious health effects during a lifetime. The RfD is derived from the no observed adverse effect levels (NOAELs) generated from studies of humans or animals. In translating RfDs into MCLGs, the EPA seeks to set a standard that 
will protect a person who drinks two liters of water per day every day for 70 years (Government Institutes, Inc. 1993).

For carcinogens, the MCLG standard-setting process is somewhat different. If there is strong evidence that a chemical is carcinogenic, the MCLG is automatically set at zero. This value is used because the EPA has been unable to determine the level at which carcinogens begin to have an adverse health effect. It is therefore conservatively assumed that any exposure to a carcinogen is potentially harmful. If there is only limited evidence that a chemical is carcinogenic, the MCLG is calculated by using the RfD approach, with an added margin of safety to account for possible cancer effects (Government Institutes, Inc. 1993).

Once an MCLG is determined, the EPA is required to specify a maximum contaminant level (MCL) that is as close as feasible to the MCLG. The MCL is the enforceable standard. Each MCL is usually accompanied by specific monitoring requirements. "Feasible" is defined as the level that may be achieved with the use of the best technology, treatment techniques, or other means that the EPA determines are available (after examination for efficacy under field conditions and not solely under laboratory conditions). The EPA must disclose the technology upon which a standard is based but may not require the use of that technology. By 1986, MCLs were established for only 16 chemicals. These included seven inorganics (arsenic, barium, cadmium, chromium, fluoride, lead, and mercury), six organics, total trihalomethanes, selected radionuclides, and microorganisms (EPA 1986). Between 1986 and 1988, the number of regulated chemicals had doubled; by 1991, that original number had tripled as the health effects became more widely known. Table A.1 in Appendix A lists the MCLs for selected years between 1972 and 1995.

Several factors are taken into account when the contaminant level achievable by the best technology is being determined. They include the removal efficiency of the technology, whether the technology is compatible with other water treatment processes, and the availability of the technology.

Unlike primary standards, secondary drinking water standards are not health-based. Instead, they are meant to guide states in controlling contaminants that may adversely affect the odor or appearance of water, causing a substantial number of the persons served to discontinue its use even though the contaminants pose no risk to public health. Within those guidelines, the EPA has the discretion to decide what standards are needed. These standards are not enforceable at the federal level, but states may adopt and enforce them (Government Institutes, Inc. 1993). 


\subsection{POSSIBLE NEAR-TERM STRATEGIES TO ADDRESS THE MOST PRESSING ENVIRONMENTAL PROBLEMS IN CHINA ON THE BASIS OF U.S. EXPERIENCE}

\subsubsection{Air}

Given the nature of current air pollution problems in China and the experience of the United States in air pollution control, it appears that the most cost-effective strategy to address these problems in China would be to follow the guidelines and requirements set forth in the 1970 CAA. This strategy would entail:

- Setting up national air pollution standards for high-risk pollutants. These could be based on current U.S. standards or even the standards currently in effect in China, which, in some cases, are more stringent than the U.S. standard. The most important air pollutants in China from a human health and welfare perspective are $\mathrm{SO}_{2}, \mathrm{NO}_{\mathrm{x}}$, ozone, and particulates.

- Developing implementation plans to meet these standards. This task is critical for dealing with air quality problems. Each region/state/urban area in China (particularly ones in which pollutant levels are high) should develop an implementation plan describing how it proposes to meet and enforce the standards set forth for various air pollutants. Each region/state/urban area should be given the freedom to determine how it will meet these standards. Usually, this task involves conducting emission inventories, using computer models, and setting emission limits for individual sources or source categories. A provision should be included that if a region/state/urban area fails to develop an implementation plan or develops an unacceptable one, the federal government may then impose its own plan upon the area.

- Making a distinction between emission limits imposed on new sources and those imposed on existing sources.

- Permitting the use of various techniques designed to make pollution control less expensive. These could include:

- Offsetting, which permits owners of new plants to obtain emission reductions from existing plants that are equivalent to the amount of the proposed emissions to be released by the new plant. 
- Emission trading policies, which allow extra pollutant reductions at some plants to be used to balance increases from sources for which control measures would be more expensive.

- For small sources (especially small industrial boilers and residential systems), imposing more stringent requirements or restrictions on the type of fuel that can be used. The feasibility of implementing district heating systems that use clean energy sources in urban areas should be explored. In Beijing alone, it is estimated that 12,111 small and medium-sized boilers, 9,154 teahouse boilers, 1,600 industrial furnaces, and 1 million small stoves were in use in $1981 \mathrm{Cu}$ 1993).

The effectiveness of these strategies in reducing urban air pollution is illustrated by the fact that imposition of similar methods in the United States (through the implementation of the 1970 CAA amendments) resulted in the following between 1967 and 1982:

- National ambient levels of $\mathrm{SO}_{2}$ decreased by $42 \%$ despite an increase in coal use and industrial activity during this period.

- In most cities, ambient levels of CO declined by approximately $40 \%$.

- In urban areas, there was a 50\% decrease in the level of particulates.

It is therefore likely that implementation of similar measures in China (especially in urban areas) would lead to similar results.

Section 4 discusses various specific air pollution control technologies that can be used to achieve the $1970 \mathrm{CAA}$ guidelines and requirements, specifically those dealing with $\mathrm{SO}_{2}, \mathrm{NO}_{\mathrm{x}}$, and particulates.

\subsubsection{Water}

Because of the diversity of water pollution problems and the pronounced differences between urban and rural areas, the approach to improving China's water should be based on the location and types of pollutants and the intended use of the water. The major pollutant categories to be addressed are pathogenic and chemical. Potential remedies are summarized in the following sections. Degradation of water quality as a result of agricultural practices is also discussed. More detailed information is presented in Section 4. 


\subsubsection{Potential Remedies for Urban Water Pollution}

Potable Water. Water treatments designed to provide a supply of potable water include filtration, disinfection, aeration, and - depending on the source of water - chemical treatment. Precipitation in the form of rain and snow contains few impurities. Substances that alter the quality of surface waters and groundwater can be classified according to the three major ways they affect water:

- Biological: Pathogens that affect public health and may be significant in modifying the physical and chemical characteristics of water.

- Physical: Substances that are related to the quality of water for domestic use, including its appearance, color, temperature, taste, and odor.

- Chemical: Chloride, metal ions, other chemicals, and substances that affect mineral content.

Water treatment systems that provide potable water generally use chlorination and ozonation to treat pathogens. Treatments for physical or aesthetic qualities may include screening, filtration, and aeration. General methods of treatment for chemical qualities may include adsorption, ion exchange, precipitation, reverse osmosis, and distillation (Corbitt 1990).

Wastewater Treatment. Municipal wastewater treatment plants accept wastewater from households, commercial establishments, and industries. These wastes are conveyed through a series of pipes and channels to the sewage treatment plant. Sewage treatment technology can be divided into several broad categories: primary, secondary, and advanced (or tertiary).

In primary treatment, wastewater flows through a screen to remove large floating objects that may interfere with the later treatment processes. After screening, the wastewater passes to a grit chamber where sand, grit, and small stones are removed. From the grit chamber, the wastewater flows into a primary clarifier where particulate matter is allowed to settle. Primary treatment removes about 30-40\% of the pollutants in the influent wastewater (Corbitt 1990).

A secondary (biological) treatment system removes about $90 \%$ of the pollutants in the influent. U.S. federal law mandates secondary treatment as the minimum treatment that must be given to all municipal sewage. In secondary treatment, the wastewater from primary treatment enters a tank where organic matter is broken down by bacteria. The most common system (activated sludge) uses an aeration tank in which the wastewater is mixed with air and with sludge loaded with bacteria. The wastewater then flows into another clarifier where the sludge settles out. In most cases, 
the wastewater is then disinfected (usually with chlorine) to remove or reduce pathogens (Corbitt 1990).

Advanced wastewater treatment most commonly adds another treatment process very similar to a secondary process at the end of secondary treatment. Other technologies such as sand filters or carbon filters can also be used. Advanced wastewater treatment usually removes more than 95\% of the pollutants in the influent (Corbitt 1990).

Potable Reuse. A common method to address water shortages is that of potable reuse. Potable reuse is the renovation of sewage effluent to a water product suitable for human consumption and the recycling of that water into a supply system. Wastewater can also be reused for nonpotable purposes, such as agriculture and industry. Potable reuse is accomplished in three general ways:

- Direct potable reuse is the reintroduction of highly treated sewage effluent from the treatment plant directly back into the existing water distribution system.

- Planned indirect reuse involves the purposeful discharge of highly treated wastewater upstream from a water supply intake.

- Groundwater recharge involves either the injection of effluent into an aquifer that is the source of potable supply or the spreading of effluent on the ground to allow it to filter down to the aquifer (van der Leeden 1990).

\subsubsection{Potential Remedies for Rural Water Pollution}

In rural areas of China, where distribution and treatment systems are limited or nonexistent, a number of low-cost technical approaches to improving water quality exist. Although some preconditions apply to the water and some resources are required, the approaches are widely used and generally successful. These methods include sedimentation in vessels or jars, infiltration galleries, rainwater catchment, spring capping with diversion to catch surface runoff, hand-dug wells (open or with bucket and pulley), hand-dug wells with handpumps, boreholes with handpumps, and gravity-fed systems with watertight reservoirs to preserve collected water (van der Leeden 1990).

The preconditions for using these methods mainly involve evaluating the source of the water to assess its quality. Addition of disinfectants such as iodide or hypochlorite, frequent cleaning of containers, maintenance of the integrity of each system, and control of activities near the system are essential. Implementation of many of these methods would require a program of education on 
how to properly use disinfection methods and protect the integrity of the system. These technologies are discussed in more detail in Section 4 (van der Leeden 1990).

Accelerated erosion on the hills of southern China and wind erosion in northwestern China contribute significantly to the sediment loading of surface water. The erosion is generally caused by agricultural practices, deforestation, and construction. It is estimated that severe soil erosion results in the Yellow River transporting 1.6 billion tons of sediment per year to the Yellow Sea. The quality of the surface water deteriorates as a result of the presence of suspended solids, pesticides, herbicides, salts, and nutrients from fertilizers. Methods for reducing the effects of accelerated erosion include protection of watersheds, construction of terraces, crop rotation, use of windbreaks, irrigation with silt-laden river water, and other land management approaches.

\subsubsection{Conclusions}

To achieve the greatest improvement for the money spent, the effectiveness of primary, secondary, and tertiary wastewater treatment methods for both domestic sewage and industrial waste were compared. Secondary treatment increases the percentage removal of biochemical oxygen demand (BOD) and suspended solids by about $100 \%$ over primary treatment. In comparison, the increased removal rates of these contaminants when tertiary treatment is implemented are only about $5 \%$ greater than those achieved through secondary treatment. The relative cost increase from primary to secondary treatment is about $200 \% / 10^{3}$ gal of water treated. The relative cost increase from primary to tertiary treatment is about $350 \% / 10^{3}$ gal of water treated (Bond et al. 1974). On the basis of these factors, water quality could be most cost-effectively improved by constructing plants for the secondary treatment of domestic and industrial wastewater.

The U.S. experience can be used to outline an approach to improving China's water quality. As they are in the United States, the primary contributors of pollutants to surface water in China include municipal and industrial discharges and nonpoint sources such as farmland and city streets.

To address industrial discharges, the United States developed technology-based effluent standards on an industry-by-industry basis rather than regulating individual dischargers. Other provisions that successfully deal with municipal and industrial discharges include those that limit the ability of facilities to get exemptions from federal pollution control regulations and those that prohibit the violation of permits or the weakening of treatment requirements when industrial and municipal discharge permits are renewed or reissued.

Chinese discharge standards are specified in terms of allowable concentrations rather than mass flow rates. A pollution levy is paid by any company that discharges pollutants exceeding allowable concentrations. This discharge fee system provides incentives to reduce discharges only to the levels specified in the standard. There is no incentive for further reduction. To provide an 
incentive to reduce the amount of waste discharged, a volume-based industrial wastewater discharge fee was begun in 1993. However, a company is not required to pay both fees. The pollution levy supersedes the volume-based fee if effluent standards are violated. These fees are considered too low to provide incentive for compliance with standards. For firms that pay discharge fees, the fees are typically less than $0.1 \%$ of the firm's total production value. By comparison, U.S. industry's environmental compliance costs are estimated to be slightly more than $1 \%$ of the total manufacturing costs. Higher fees could increase compliance (Florig 1995).

To provide U.S. cities with a minimum amount of secondary treatment for sewage, federal grant programs were established to finance construction of municipal wastewater treatment systems. This program was phased out over a number of years and replaced by a another federal program that provides seed money for states to establish permanent, state-run, revolving-fund programs. The revolving funds, to which states must also contribute, are used to provide loans and other forms of nongrant assistance to local areas to construct wastewater treatment systems, with loan repayments channeled back into the state funds and reused. This program ended the federal government's role in financing construction of local wastewater treatment plants, but it still provides a continuing source of money for construction of such facilities, thereby ensuring progress toward the goal of clean water (BNA 1991).

In China, the fees and fines collected support EPB operations and subsidize pollution control projects for companies that have paid into the levy system. Local EPBs may use $20 \%$ of the fees and $100 \%$ of the fines to fund their activities. Up to $80 \%$ of the fees are allocated for pollution control loans to companies that have paid into the pollution levy system. A number of observers have noted that the pollution control incentive provided by the Chinese levy system is low because fees are small relative to the costs of implementing pollution control. Fees are not indexed for inflation, and for state-owned companies, fees can be included under costs and recouped later through price increases or tax deductions. Also, because the fees and fines can be lower than the cost of operating and maintaining pollution control equipment, companies that do install the equipment have little incentive to operate it (Florig 1995). If the EPB were supported by the government and if fees and fines were increased significantly, the incentives to control pollution would be improved in several ways: more money would be available for loans for pollution control equipment, and companies would have a greater incentive to operate and maintain equipment once it was installed.

The United States found that even after municipal and industrial discharges were wellregulated, the nonpoint sources contributed much more than anticipated to pollution. A waterquality-based approach was needed to address this nonpoint source pollution. Nonpoint source pollution control provisions were instituted that required states to identify waters sources not expected to meet quality standards and to develop programs for reducing pollutant runoff. Currently, China has little in the way of local controls to address nonpoint sources. One of the most pressing problems is that of erosion (BNA 1991). 
The Yellow River is a major source of irrigation water; its sediment concentrations are among the highest in the world. Sediment enters the river as the river flows past several deserts and passes through a loess plateau. It is estimated that severe soil erosion causes the Yellow River to transport 1.6 billion tons of sediment to the Yellow Sea every year. A study to reclaim and restore the land at Yanchi Station is being used as a blueprint for the future. Land management is coordinated and includes the control of grazing in the desert-margin environments and education for the peasant farmers. Other land management features control removal of vegetation in the margin areas (Fullen and Mitchell 1994).

In December 1994, China's NEPA began a two-year study of a pollution fee system. The study will address four main areas: designing mass-flow levy formulas for pollutants, with fee schedules based on costs of pollution control; designing a pollution levy fund to include institutional arrangements, technical assessment of loans, and priorities for using the fund; designing an information management system for calculating fees and maintaining billing and receipts; and dealing with practical issues of implementation (effluent monitoring, calculating and collecting fees, fund management). The results of this study should help resolve issues and remove obstacles that prevent the improvement of water quality (Fullen and Mitchell 1994).

\subsubsection{Soil}

The primary sources of soil contamination and degradation were summarized in Table 3 . The major categories of pollutants addressed in this report are chemical contamination by industry and agriculture. Remedies for soil contamination include modifying activities to eliminate obvious sources of contamination and implementing available technologies to treat soil. Technologies that are considered proven in the United States are summarized in the following sections and discussed in more detail in Section 4.

\subsubsection{Potential Remedies for Chemically Contaminated Soil}

Organic Compounds. Treatment technologies for volatile and semivolatile organic contaminants include soil vapor extraction (SVE), thermal desorption, incineration, biodegradation, and excavation with disposal. On the basis of U.S. experience, these technologies treat wastes effectively in place at a relatively low cost (EPA 1994).

Inorganic Compounds. Technologies for the treatment or containment of inorganic contaminants such as arsenic, lead, cadmium, chromium, mercury, selenium, and radionuclides can 
include chemical treatment (oxidation/reduction), stabilization and solidification, capping, and excavation (EPA 1994).

Petroleum Hydrocarbons. Fuels may contain both volatile and semivolatile organic compounds. Therefore, depending on the type of fuel present, the treatment methods listed above are also applicable for soil, sediment, and sludge containing fuel. Additional methods that are very successful and cost effective include low-temperature thermal desorption and several types of biodegradation such as in-situ biodegradation, composting, and landfarming (EPA 1994).

\subsubsection{Conclusions}

The approach taken by the United States to manage solid wastes has been successful in controlling waste disposal, encouraging waste minimization, and promoting recycling. The regulations for enacting the Resource Conservation and Recovery Act (P.L. 94-580, approved October 21,1976 ) govern the permitting of treatment, storage, and disposal facilities. They allow the EPA to identify and monitor the activities of individual facilities and to impose fines and conditions on those that violate permit conditions. One of the most effective components is waste manifesting, which essentially tracks wastes from the point of generation to disposal. By providing a closed-loop accounting system for wastes, this tracking process has helped to control illegal dumping and improper disposal practices. As a result, waste volumes have decreased, and the use of biodegradable materials, recycling, and reuse have increased.

One of the goals of the act was to force development of treatment technologies. Land disposal is the least preferred method of disposal for a number of reasons: it can pose risks to human health and the environment, suitable land disposal areas are limited, long-term containment is uncertain, and restoration of land disposal areas is expensive. Land disposal in China presents similar problems. Currently, China is encouraging the growth of the environmental products industry by establishing an environmental products market and by creating special parks for environmental protection industries to allow them to take advantage of economies of scale. China could provide further incentives for the development of new technologies by providing tax breaks, bonuses, or foreign business opportunities (Florig 1995).

Although environmental programs in China are growing, compliance is most effective in the large new facilities, because abatement equipment was incorporated in their design. Enforcement and monitoring must be strengthened for small-scale and rural facilities. This goal could be accomplished by strengthening environmental laws and taxing existing industries. Price reforms for raw materials and retention of profits could be used more extensively to increase the incentive for industry to produce less waste. For example, water is still priced below its scarcity value in most areas (Florig 1995). 
The U.S. experience has shown the strength and effectiveness of well-organized citizen groups. Although local Chinese EPBs are receptive to citizen complaints, the Chinese government is reluctant to allow the formation of independent environmental groups (Florig 1995). If these groups were allowed, they could actually ease the government's enforcement burden because they could pressure violators to comply with the existing laws. 


\section{TECHNICAL OPTIONS FOR CONTROLLING ENVIRONMENTAL POLLUTION IN CHINA}

This section discusses some of the control options that could be implemented in China to deal with its air, water, and soil pollution problems. These control strategies could be used to meet some of regulatory options suggested in Section 3 . The technologies selected for discussion here are considered to be common, currently available technologies that can be used to control air pollution or clean contaminated liquids (e.g., surface water and groundwater) or solids (soil, sediment, and sludge). The descriptions are somewhat general so that the control technologies can be understood by a person who is not an expert. At the same time, enough information is presented so that readers can understand what the technologies are and what is required to make them work. The descriptions explain the purpose of each technology and the types of contaminated environmental media to which each technology applies.

\subsection{AIR POLLUTION}

\subsubsection{General Introduction and Background}

This section describes technologies that can be applied to control air pollution from both utility and industrial sources in China. Here, the single largest source of air pollution is coal combustion; it accounts for up to $80 \%$ of China's air pollution. Furthermore, it has been estimated that $75 \%$ of the particulate matter, $90 \%$ of the $\mathrm{SO}_{2}$, and $67 \%$ of the $\mathrm{NO}_{\mathrm{x}}$ can be attributed to coal combustion. However, unlike the utilities in other major coal-consuming countries, the utility sector in China consumes only about $30 \%$ of the coal, while the industrial sector consumes about $50 \%$. The remaining $20 \%$ of the coal is consumed by the residential and commercial sectors. This section focuses on the controls that are applicable to utility and industrial coal-fired boilers. Particulate controls for coal combustion are also applicable for steel and cement manufacturing, two other large industrial pollution sources. Particulates make up a large percentage of the emissions from these two sources.

There are three types of controls for air pollution resulting from coal combustion. They are precombustion controls, combustion controls, and postcombustion controls. This section discusses the technologies that are applicable for each method of control. The discussion includes a brief description of the technology, its efficiency in removing pollutants, and preliminary information on the cost of implementing the technology. 


\subsubsection{Descriptions of Specific Technologies}

\subsubsection{Coal Cleaning}

This precombustion technology will benefit all coal-consuming sectors. It involves removing noncombustible particles and ash from raw coal. Because cleaning removes noncombustible material before combustion, it increases the heating value and decreases the variability in the quality of coal delivered to the end user. This better coal improves the efficiency and reliability of the boiler and lowers boiler emissions and ash disposal requirements. Transportation costs and emissions can also be reduced as a result of cleaning coal at the mine, since cleaning removes large amounts of dirt, rocks, and other inert material that would otherwise be transported to the end user. China currently cleans only about 200 million metric tons $(t)$ or about $18 \%$ of the raw coal production. It hopes to increase cleaning capacity to $300-350$ million $t$ by the year 2000 (Bhatti et al. 1994). However, this amount represents only about $33 \%$ of the raw coal production. In the United States. more than $50 \%$ of the domestically mined coal is cleaned. Because of China's large coal reserves, cleaning more coal could have the side benefit of increasing opportunities for coal exports, thereby increasing foreign exchange.

Most coal cleaning is performed by physical separation. The cleaning process is based primarily on the differences in specific gravity or surface properties between coal and its impurities. Wet or dry processes are used for physical coal cleaning. Physical cleaning can remove only matter that is physically distinct from the coal, such as small dirt particles, rocks, and pyritic sulfur (sulfur combined with iron particles). Physical cleaning cannot remove sulfur that is chemically combined with coal (organic sulfur), nor can it remove nitrogen from coal. Currently, physical cleaning can remove $30-50 \%$ of the pyritic sulfur (or $10-30 \%$ of the total sulfur) and about $60 \%$ of the ashforming minerals in coal (DOE 1994). Therefore, when cleaned coal instead of raw coal is used in boilers, $\mathrm{SO}_{2}$ emissions can be reduced by $10-30 \%$, and particulates (which result from ash in coal) can be reduced by as much as $60 \%$, depending on the type of boiler. Solid waste disposal requirements from boilers are also reduced. Advanced physical as well as chemical and biological cleaning processes show good potential for higher levels of cleaning (i.e., higher levels of pyritic and organic sulfur removal as well as additional ash removal) and are currently being developed. Physical coal cleaning costs range from $\$ 2$ to $\$ 3 / t$ (IEA Coal Research 1993), depending on coal characteristics, level of cleaning, plant size, etc.

\subsubsection{Briquettes}

Use of briquettes can be considered a precombustion control. Raw coal is processed into briquettes before it is used. The briquettes are "formed" pieces of coal that have gone through a devolatilization process. Currently, $67 \%$ of residential cooking energy is from briquettes, and by the 
year 2000 , all urban residents will use briquettes. When briquettes are used in place of raw coal, particulate emissions can be reduced by $50 \%$, and emissions of sulfur oxides $\left(\mathrm{SO}_{x}\right)$ can be reduced by $40 \%$ if a sulfur absorber is incorporated into the briquette (Siddiqi et al. 1994). Briquettes can also be used in industrial boilers, especially stokers, which are prevalent in China. If clean fuel requirements are imposed on industrial boilers, use of briquettes would be one way to comply.

\subsubsection{Combustion Modification for $\mathrm{NO}_{\mathrm{x}}$ Control}

$\mathrm{NO}_{\mathrm{x}}$ emissions from boilers are directly influenced by the combustion process. $\mathrm{NO}_{\mathrm{x}}$ formation is a complex process that depends primarily on boiler and burner design. Because of this, combustion modification techniques are the most common and cost-effective means of reducing $\mathrm{NO}_{\mathrm{x}}$ emissions. Combustion modifications reduce $\mathrm{NO}_{\mathrm{x}}$ formation by minimizing peak combustion temperatures, restricting the amount of oxygen available to combine with nitrogen, and forming fuel-rich reducing zones that convert $\mathrm{NO}_{\mathrm{x}}$ back to nitrogen. Some of these techniques include low-NO ${ }_{x}$ burners (LNBs), low excess air (LEA), and staged combustion (SC).

Low-NO ${ }_{x}$ burners can be retrofit on pulverized coal boilers, which make up most of the utility plant boilers. Pulverized coal boilers are generally not used in industrial applications. The burners can reduce $\mathrm{NO}_{x}$ emissions by $50-75 \%$. In utility applications, the capital costs are about $\$ 12 / \mathrm{kW}$, and annual operation and maintenance (O\&M) costs are about $0.1 \mathrm{mill} / \mathrm{kWh}$ (NAPAP 1990). However, retrofit costs and performance depend on the type of boiler and the complexity of the installation.

Low excess air and staged combustion are two other technologies that are applicable for retrofit to either utility or industrial boilers. However, these technologies are particularly applicable to stoker-fired industrial boilers, which appear to make up a large share of industrial boilers in China. Both are established technologies, with $\mathrm{NO}_{\mathrm{x}}$ reductions ranging from $17 \%$ to $38 \%$ for low excess air and from $10 \%$ to $60 \%$ for staged combustion. Capital costs for LEA retrofits to industrial boilers range from $\$ 125,000$ to $\$ 188,000$, and those for $S C$ retrofits range from $\$ 125,000$ to $\$ 300,000$ (NAPAP 1990). Costs and performance depend on the type of boilers and the complexity of the installation.

\subsubsection{Clean Coal Technologies}

There are several advanced coal combustion technologies that can be used for new utility or industrial boilers and for repowering existing boilers. Repowering is the extensive refurbishment of a unit to extend its life and often includes replacing the existing boiler. These technologies not only increase combustion efficiency and unit capacity but can also reduce particulate, $\mathrm{SO}_{2}$, and $\mathrm{NO}_{\mathrm{x}}$ emissions during the combustion process. The removal efficiencies are generally so large that 
additional emission controls are not needed. Two such technologies applicable to China are fluidized-bed combustion (FBC) and integrated gasification combined-cycle (IGCC) technology.

In FBC, coal burns in a furnace as a strong upward current of air suspends (or fluidizes) the crushed coal and mixes it with a "bed" of limestone particles. As the coal burns, sulfur is released, and the limestone captures the sulfur before it can escape from the boiler. The sulfur chemically combines with the limestone to form a new solid waste product, which is a mixture of calcium sulfite and calcium sulfate. $\mathrm{NO}_{x}$ emissions are also reduced because of the lower combustion temperatures. Some of the solid waste is removed with the bed of ash through the bottom of the boiler. Small ash particles, or fly ash, that escape from the boiler are captured with dust collectors (such as baghouses). The waste product can be used as a construction material. Removal efficiencies exceed $90 \%$ for $\mathrm{SO}_{2}$, are $50-90 \%$ for $\mathrm{NO}_{\mathrm{x}}$, and exceed $95 \%$ for particulates. Units are designed to operate either under atmospheric conditions (known as atmospheric FBCs) or pressurized conditions (known as pressurized FBCs). Capital costs in utility repowering applications can range from $\$ 700$ to $\$ 900 / \mathrm{kW}$, and new plants can average about $\$ 1,300 / \mathrm{kW}$ (DOE 1994).

The IGCC technology combines coal gasification and electricity generation processes. Coal is not burned directly but is first converted into a clean-burning synthesis gas, which is then used in an efficient combined-cycle gas-turbine system. Sulfur, nitrogen compounds, and particulates are removed in the gasification process. Removal efficiencies exceed $98 \%$ for $\mathrm{SO}_{2}$, are $70-95 \%$ for $\mathrm{NO}_{\mathrm{x}}$, and are $98 \%$ for particulates. This technology is also effective in reducing emissions of trace metals like mercury and lead as well as VOCs. The slag and sulfur by-products of the IGCC process can be sold as construction material and chemical feedstocks, respectively. Also, IGCC combustion efficiencies exceed $40 \%$, compared with $34 \%$ (or less) for conventional coal-fired power plants. Capital costs in utility repowering applications can range from $\$ 950$ to $\$ 1,200 / \mathrm{kW}$, and new plants can average about $\$ 1,250 / \mathrm{kW}$ (DOE 1994). China has significant interest in this technology, and according to the Electric Power Research Institute (EPRI), China is pursuing construction of a 200MW to 400-MW demonstration project.

If stricter air pollution limits were to be placed on new coal combustion sources, these technologies could be used to comply. Furthermore, if an existing boiler were to be scheduled to undergo a major refurbishment to extend its expected lifetime, one of these clean coal technologies could be added at that time. Such a technology would not only allow the boiler to comply with pollution limit requirements but could also offset another boiler's "excess" emissions.

\subsubsection{Flue-Gas Desulfurization}

Flue-gas desulfurization (FGD or "scrubbers") is a postcombustion technology for removal of $\mathrm{SO}_{2}$ emissions that is applicable to utility and industrial boilers of all types. Sulfur removal is achieved by chemical reaction of the flue gas with a sorbent to remove $\mathrm{SO}_{2}$. FGDs can be either wet 
or dry systems and are installed in the ductwork after the boiler. In wet scrubbing, flue gas is sprayed with a slurry of water and an alkaline reagent, usually limestone. $\mathrm{The}^{\mathrm{SO}_{2}}$ in the flue gas reacts with the limestone to produce a wet mixture of calcium sulfite and calcium sulfate, which is commonly referred to as scrubber sludge. In dry scrubbing (or a spray dryer), the reagent mixture (usually lime) is injected as a finely atomized mist. The droplets evaporate in the hot gas, leaving only dry particles to react with the $\mathrm{SO}_{2}$ and to be collected subsequently as a dry by-product. Although an FGD unit can produce a large amount of by-product, the by-product may not necessarily be disposed of as waste. The by-product from wet scrubbing can be used to create gypsum for drywall manufacture, and some of the by-product from dry scrubbing is recycled back into the process. $\mathrm{SO}_{2}$ removal efficiencies for both types of FGDs can exceed $90 \%$.

Postcombustion $\mathrm{SO}_{2}$ control is extremely rare in China. Only two coal-fired utility boilers (about $720 \mathrm{MW}$ total) currently use FGDs. Hence, there is a great opportunity to control $\mathrm{SO}_{2}$ emissions by using FGD, particularly on large, high-capacity-factor, coal-fired boilers.

The main difference between industrial and utility applications of FGDs is in the type of sorbent used. Industrial boilers mainly use wet scrubbers with sodium or dual alkali as the sorbent, while utility boilers use lime or limestone as the sorbent (both wet and dry). Different sorbents are used in industrial FGDs because of lower process complexity. Worldwide, sodium FGD systems have been installed on industrial boilers with as little as $1 \mathrm{MW}$ of heat input. Generally, FGDs on industrial boilers are more cost-effective when capacity factors exceed $30 \%$.

In the past, a disadvantage of FGDs was the large amount of power they used, which resulted in reducing power plant efficiency by as much as 5\%. However, current FGD units have very low power requirements and reduce plant efficiency by less than $1 \%$. Also, both capital and O\&M costs have been decreasing. Retrofit capital costs of utility units range from $\$ 150$ to $\$ 250 / \mathrm{kW}$ (ICAC 1994a), and annual O\&M costs are about $1.5 \mathrm{mill} / \mathrm{kWh}$ (Weilert and Dyer 1995). Low-cost industrial FGDs with capital costs of about $\$ 50 / \mathrm{kW}$ have been developed in Japan (IEA Coal Research 1995).

\subsubsection{Particulate Control}

Particulates can be removed from the exhaust gas stream (postcombustion control) of industrial or utility boilers by baghouses or electrostatic precipitators (ESPs). These types of particulate controls can also be used in the steel and cement manufacturing industries to control exhaust gas particulate emissions. Currently, in China, postcombustion pollution control is virtually nonexistent except for large (more than $200 \mathrm{MW}$ ) power plants located in or near large cities, which may have particulate control (mostly ESPs). Hence, particulate emissions could be substantially reduced by employing a particulate control technology. 
In a baghouse, exhaust gases are passed through a fabric bag (either natural or synthetic fiber) that traps the particulates before they have been discharged into the atmosphere. It is an established technology that has been used for many years in developed countries and is capable of removing more than $95 \%$ of the particulates from the exhaust gases. In utility applications, capital costs of baghouses are about $\$ 56 / \mathrm{kW}$, and annual O\&M costs are about $\$ 7.5 / \mathrm{kW}$-yr (adapted from Shoat et al. 1993).

An ESP uses electrical forces to remove particulates out of the exhaust gas stream and onto collector plates. It is very similar to a residential electronic air cleaner. This established technology, which has been used for many years in developed countries, can remove more than $95 \%$ of the particulates from exhaust gases. In utility applications, capital costs of ESPs are about $\$ 72 / \mathrm{kW}$, and annual O\&M costs are about $\$ 5.6 / \mathrm{kW}$-yr (adapted from Shoat et al. 1993).

\subsubsection{Postcombustion $\mathrm{NO}_{\mathrm{x}}$ Control}

There are two types of postcombustion $\mathrm{NO}_{x}$ controls: selective catalytic reduction (SCR) and selective noncatalytic reduction (SNCR). SCR is applicable not only to utility and industrial coal-fired boilers but also to gas and oil-fired units. In SCR technology, ammonia is sprayed into the ductwork after the flue gas exits the boiler. The flue gas then enters a reactor vessel containing a catalyst that facilitates a chemical reaction between $\mathrm{NO}_{\mathrm{x}}$ and ammonia to produce nitrogen and water. The only waste produced is spent catalyst, which the EPA has classified as nonhazardous. $\mathrm{NO}_{\mathrm{x}}$ removal efficiencies range from $70 \%$ to $90 \%$. Currently, about 230 SCR units have been installed worldwide on coal-fired stations (about $65 \mathrm{GW}$ ). In utility applications, capital costs are about $\$ 65 / \mathrm{kW}$ (ICAC 1994b), and annual O\&M costs are about 1.3 mills $/ \mathrm{kWh}$ (Baldwin et al. 1995). However, cost and performance depend on the complexity of the installation. Costs have been dropping rapidly as more experience has been gained.

SNCR is applicable to utility and industrial coal-fired boilers. In this technology, ammonia or urea is injected into the combustion gases above the combustion zone in the boiler. Nitrogen and water are formed in the reaction without the use of a catalyst. No liquid or solid wastes are produced in this process, and $\mathrm{NO}_{\mathrm{x}}$ removal efficiencies range from $30 \%$ to $75 \%$. Most currently operational SNCR units are on industrial boilers. In utility applications, capital costs are about $\$ 12 / \mathrm{kW}$, and annual O\&M costs are about 2.3 mills/kWh (ICAC 1994c). As was the case for SCR technology, cost and performance depend on the complexity of the installation.

\subsubsection{Conclusions}

This section has briefly identified and described air pollution control technologies that might be applicable in the utility and industrial sectors in China. Currently, China's level of air 
pollution control is low, especially with regard to coal combustion. All of the aforementioned technologies can be applied to coal-fired boilers. Moreover, all of the technologies are currently in commercial use and available from many different foreign vendors.

When these pollution control technologies are applied, the greatest benefits will likely be gained by controlling the largest emitters first. Also, controls should be instituted first on sources that directly affect areas of the country that have significant pollution problems. This strategy is investigated in the next part of the study.

Coal cleaning would benefit all coal combustion sectors, since it increases boiler efficiencies and reliability and decreases both air emissions and solid wastes. China plans to increase coal cleaning capacity so that about $33 \%$ of the raw coal will be cleaned. However, it may be advantageous to increase coal cleaning capacity even more, since cleaned coal could be exported, thereby increasing China's foreign exchange.

Several technologies might be employed on a single unit, depending on the emission limits placed upon it. For example, an FGD unit, $\mathrm{NO}_{\mathrm{x}}$ combustion control, and a baghouse could be installed on the same plant to control $\mathrm{SO}_{2}, \mathrm{NO}_{\mathrm{x}}$, and particulates on a boiler. If $\mathrm{SO}_{2}$ needs to be controlled to a greater degree than the level that can be achieved by an FGD unit alone, cleaned coal can be used.

\subsection{WATER POLLUTION}

Wastes in Chinese water come from two primary sources: domestic and industrial sources. The major classes of pollutants that have been identified in the surface waters of the China include organic wastes, suspended matter (such as toxic solids), bacteria, and other pathogens. Within these classes are arsenic, mercury, chlorinated hydrocarbons, pesticides, oils, nitrogen, and phosphorus. The presence of these pollutants also results in the indirect contamination of groundwater and soil.

\subsubsection{Domestic Water Treatment}

The most important objective of water treatment is to produce a water that is biologically and chemically safe for human consumption. The principal contaminants found in water and the processes used for their removal are summarized in Table 12. Only chemical and physical processes are used because appreciable amounts of organic matter are not present in most natural waters. In general, effluents from biological treatment processes do not meet source standards for domestic water supplies. 
TABLE 12 Processes and Treatment Systems Used to Remove the Major

Contaminants Found in Water

Contaminant

Process or Treatment System

Pathogenic organisms

Turbidity and suspended matter

Color

Tastes and odors

Organic matter

Hardness ions, $\mathrm{Ca}^{+2}, \mathrm{Mg}^{+2}$

Dissolved gases

Heavy metals

Iron and manganese

Dissolved solids
Chlorination, ozonation

Screening, sedimentation, filtration, coagulation/ flocculation/ sedimentation/filtration ${ }^{\mathrm{a}}$

Adsorption, ion exchange, coagulation/flocculation/ sedimentation/filtration

Oxidation (aeration), adsorption, chemical oxidation

Adsorption, ion exchange, ozonation, coagulation/

flocculation/sedimentation/filtration

Chemical precipitation

Aeration, chlorination, ion exchange

Chemical precipitation, ion exchange

Ion exchange, oxidation/precipitation/filtration

Reverse osmosis, distillation

a Treatment system consisting of several combined process operations.

The treatment required for a particular body of water depends on the water's source. For example, the treatment of water from a remote mountain catchment area may involve screening, filtration, and disinfection, whereas the treatment for river water may involve screening, coagulation/flocculation, sedimentation, filtration, and disinfection. Because rivers provide a source of drinking water in China, a typical flowsheet for the complete treatment of river water is shown in Figure 2. The coagulation/flocculation, sedimentation, and filtration treatment steps remove turbidity and pathogenic organisms. Precipitate is removed by gravity sedimentation followed by filtration, which removes any residual solids remaining after sedimentation. Disinfection is used to control pathogenic organisms. After it is disinfected, the treated water can be stored or consumed. Sludge removed from the settling basin is usually disposed of in lagoons, where drying is usually completed within six months. Because lagoons are used for storage and drying, a minimum of two lagoons is required.

\subsubsection{Wastewater Treatment}

The principal objective of wastewater treatment is to produce an effluent to be discharged without causing serious impacts to human health and the environment. The principal contaminants found in wastewater and the processes used for their removal are summarized in Table 13. Except 


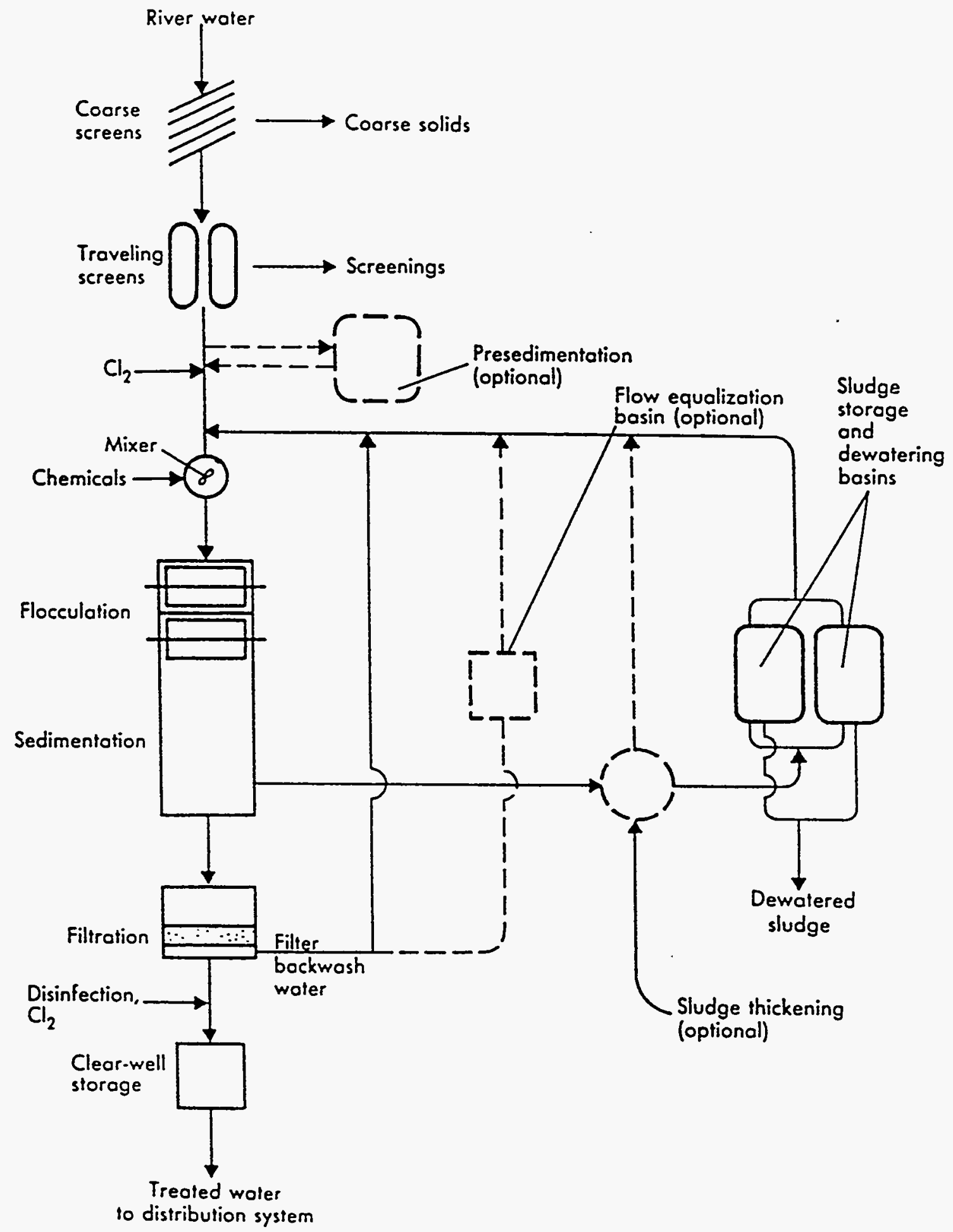

FIGURE 2 Flow Diagram of Complete Treatment of River Water (Source: George Tchobanoglous/Edward Schroeder, Water Quality: Characteristics, Modeling, Modification. (C) 1985 Addison-Wesley Publishing Company Inc. Reprinted by permission of AddisonWesley.) 
TABLE 13 Processes and Treatment Systems Used to Remove the Major Contaminants Found in Wastewater

Contaminant

Process or Treatment System
Screening and comminution, sedimentation, flotation, filtration, land treatment, coagulation/sedimentation

Biodegradable organics

Activated sludge, trickling filters, rotating biological contactors, aerated lagoons, oxidation ponds, intermittent sand filtration, land treatment, physical/chemical treatment

Pathogenic organisms

Chlorination, ozonation, land treatment

Nutrients:

Nitrogen

Phosphorus

Refractory organics ${ }^{\mathrm{a}}$

Heavy metals

Dissolved inorganic solids
Suspended-growth nitrification and denitrification, fixed-film nitrification and denitrification, ammonia stripping, ion exchange, breakpoint chlorination, land treatment

Metal salt coagulation/sedimentation, lime coagulation/sedimentation, biological/chemical phosphorus removal, land treatment

Carbon adsorption, tertiary ozonation, land treatment

Chemical precipitation, ion exchange, land treatment

Ion exchange, reverse osmosis, electrodialysis

a Organics that tend to resist conventional biological methods of wastewater treatment. Typical examples include surfactants, phenols, and agricultural pesticides.

for biological treatment, the processes and operations used in wastewater treatment are similar to those used in domestic water treatment. Biological treatment is used for removing easily biodegradable organic compounds, nitrogen, and phosphorus.

The treatment required for wastewater depends on the effluent to be discharged. Treatment schemes are generally identified as primary, secondary, or tertiary. In primary treatment, a portion of the suspended solids and organic matter is removed from the wastewater, usually by means of physical operations such as screening and sedimentation. The material is then placed in primary settling tanks, where it may be treated with coagulants to flocculate some of its suspended organic matter. The effluent from primary treatment ordinarily contains considerable amounts of organic material and has a relatively high biochemical oxygen demand (BOD).

The further treatment of the effluent from primary treatment to remove the residual organic matter and suspended material is known as secondary treatment. In general, biological processes using microorganisms are used to oxidize the organic matter present in the sewage, reduce the amount of inorganics, and inactivate pathogenic microorganisms. Secondary treatment usually occurs in two stages. During the first stage, the sewage is treated by one of the following methods: 
filtration by trickling filters, intermittent sand filters, or rotating disks. The second phase may include oxidation ponds or aeration by the activated sludge. The effluent from secondary treatment usually has low BOD and few suspended solids and may contain several milligrams per liter of dissolved oxygen.

Until the 1970s, the effluents resulting from primary or secondary sewage treatment were discharged without further processing. Public health considerations have since dictated that the effluents receive further treatment (physical, chemical, or both). The goal of tertiary treatment is to lower concentrations of BOD, ammonia, nitrates, phosphates, heavy metals, and organic compounds. It is also used to inactivate any pathogenic bacteria, enteric viruses, protozoan cysts, and helminth eggs that have passed through the previous treatments. Tertiary treatment can include reverse osmosis, ammonia stripping by air, coagulation with lime and alum, sand filtration, carbon adsorption, and disinfection. A typical flow diagram for wastewater treatment and reclamation is shown in Figure 3.

\subsubsection{Industrial Water Treatment}

\subsubsection{Bioremediation}

The biological treatment of contaminated water has an extensive history. Thus the technology is predictable, and the impacts can be evaluated and scaled easily (Woodyard 1991). Biotreatment is used extensively for municipal wastewaters. It can take place under aerobic or anaerobic conditions. The requirements of the technology depend on the method used.

Biotreatment - also known as bioremediation - refers to a range of processes that rely on the breakdown of organic contaminants in liquid by the metabolic action of microorganisms, such as bacteria, or by chemical reactions of enzymes produced by the organisms. This treatment process - also known as biodegradation, biorestoration, or bioreclamation - creates physical, chemical, and biological conditions that promote microbial degradation in the contaminated medium, thereby stimulating or accelerating the biodegradation of the target contaminants. The ultimate goal of bioremediation is to convert organic wastes into biomass and harmless by-products of microbial metabolism, such as $\mathrm{CO}_{2}$, water, and inorganic salts. Biological treatment typically consists of optimizing environmental conditions to stimulate the growth of microorganisms that will feed on targeted contaminants. 
PRIMAAY TREATMENT
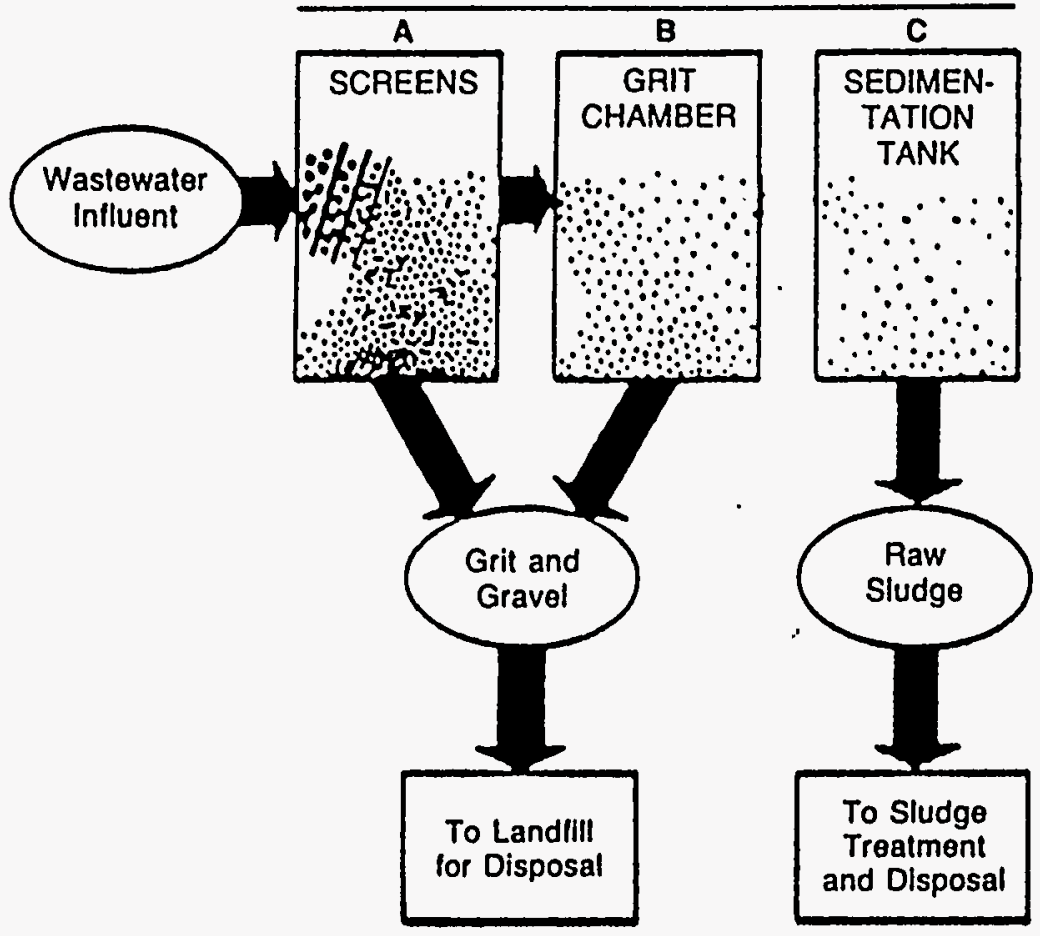

SECONDARY TREATMENT

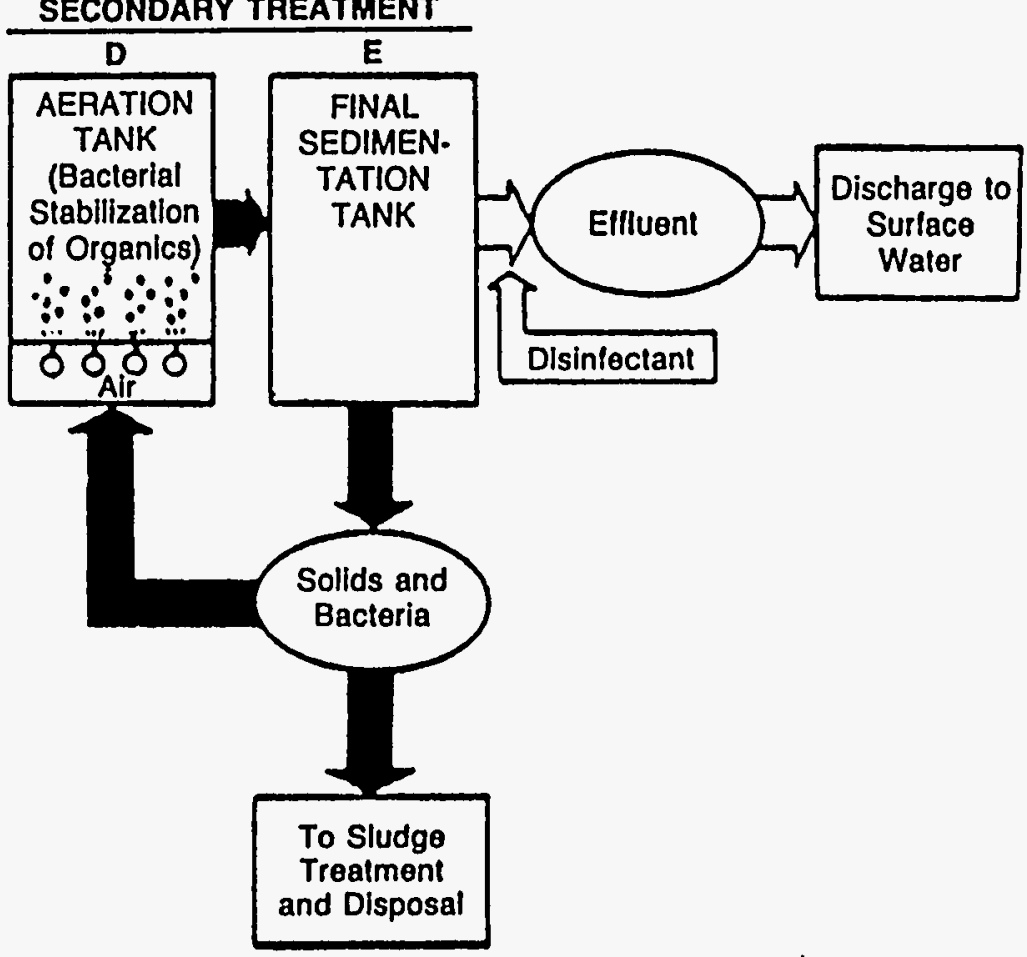

FIGURE 3 Typical Flow Diagram of Wastewater Treatment and Reclamation (Source: U.S. Environmental Protection Agency) 


\subsubsection{Physical Treatment}

Physical treatment processes separate the waste stream by either applying physical forces or changing the physical form of the waste. These methods generally do not destroy the contaminants in the waste stream, and they differ in their applicability to various types of wastes and their need for pretreatment and posttreatment procedures. The physical processes considered here are carbon sorption, precipitation, and filtration.

Carbon Sorption. Carbon sorption (adsorption) uses a solid material with a high surface area or permeability that selectively adsorbs organic contaminants from liquid waste streams. This technology is usually considered only for removal of organic contaminants as part of a treatment train (i.e., a series of treatment technologies). The process can be defined as the accumulation of substances at the interface of two phases. For water treatment, the interface is between liquid and solid surfaces. The material removed from the liquid phase is called the adsorbate, and the material providing the solid surface is called the adsorbent.

The adsorbent most commonly used in water treatment is activated carbon, a carbonaceous material that has been "activated" by burning and oxidation to create a solid with irregular channels and pores. The resulting product has a very large ratio of surface area to mass. Dissolved organic contaminants adsorb to the interior and exterior surfaces of the activated carbon. When the surfaces are covered, the carbon must be regenerated. The regeneration process is essentially the same as the original activation process.

Precipitation. Precipitation is a physicochemical process in which some or all of a substance in solution is transformed into a solid phase. The basis of the process is the alteration of the chemical equilibrium relationships that affect the solubility of inorganic species. All precipitation processes are governed by the same fundamental chemical principles and use similar types of equipment and process configurations. The process is nonselective in that compounds other than those targeted may be removed. Because the pretreatment and posttreatment requirements are comparable, regardless of the specific precipitation method, this technology is discussed generically; specific systems are not addressed.

The most common application of this technology to wastewater treatment is for removing metals as hydroxides or sulfides. Generally, lime or sodium sulfide, along with flocculating agents, ${ }^{1}$

1 Flocculation refers to the process by which small, unsettled particles suspended in a liquid medium are made to agglomerate into larger particles. The fluffy, gelatinous particles enmesh small particles. Typically, the chemicals used to cause flocculation include alum, lime, various iron salts (ferric chloride, ferrous sulfate), and organic flocculating agents, often referred to as polyelectrolytes. The materials consist of long-chain, watersoluble polymers such as polyacrylamides. 
is added to the wastewater in a rapid mixing tank. The wastewater flows to a flocculation chamber, where adequate mixing and retention time is provided for agglomeration of precipitate particles. Agglomerated particles are separated from the liquid phase by settling in a sedimentation chamber or by filtration. This technology can also be integrated into a treatment train (a combination of treatment technologies in series), in which the effluents produced by the preceding treatment units can be treated.

Precipitation can be used to remove most metals from wastewater, including zinc, cadmium, copper, fluoride, lead, manganese, and mercury. Certain anionic species - such as phosphate and sulfate - can also be removed by precipitation. Although precipitation is useful for treating most aqueous hazardous waste streams, its effectiveness may be limited by certain physical or chemical characteristics. In some cases, organic compounds, cyanide, and ionic species may complex with metals, making precipitation less efficient.

Filtration. Filtration is a physical process that removes suspended solids from liquid streams when the fluid is forced through a porous medium. The result is a filter medium containing the suspended solids. Polishing filtration is used to treat wastewater that contains relatively low concentrations of solids (less than $1,000 \mathrm{mg} / \mathrm{L}$ ). It removes particles that are difficult to settle because of their size and density. The two most common polishing filtration processes are granular and cartridge filtration. Both processes remove particles that are much smaller than the pore size of the filter medium by straining, adsorption, and flocculation. This type of filtration cannot effectively remove particles in the colloidal ${ }^{2}$ range (EPA 1985).

Granular media filtration is used to treat aqueous waste streams. The filter medium consists of a bed of granular particles (typically sand or sand with anthracite or coal). A cartridge filter can be used for low-flow waste streams. It is a hollow, cylinder-shaped cartridge with a matted clothtype filter medium in a sealed vessel. Wastewater is pumped through the wall of the cartridge through the filter. When the filter becomes plugged, the cartridge is replaced. Used cartridges require treatment or disposal.

\subsubsection{Chemical Treatment}

Chemical treatment alters the chemical structure of the constituents to produce a waste residue that is less hazardous than the original waste stream. The chemical treatment processes discussed in this section are ion exchange, chemical oxidation, and chemical reduction (redox). Redox is used for treating a number of commonly encountered contaminants. Its basis is

2 Colloids are particles with one or more dimensions that lie in the range between 1 millimicron (nanometer) and 1 micron (micrometer). 
reduction/oxidation reactions between waste components and added reactants in which the oxidation state is either raised or lowered.

Ion-exchange and oxidation/reduction technologies for water have been used extensively for wastewater treatment for more than 40 years. They are established technologies that perform well for this application and are commercially available from a number of vendors. The units are relatively compact and not energy-intensive. Start-up and shutdown can be accomplished easily, and the volume of wastes produced is conservative.

Ion Exchange. Ion exchange is a versatile and effective treatment technology that can be used to treat aqueous wastes such as water containing industrial contaminants. Ion-exchange resins are mainly synthetic organic materials that selectively remove specific ions, are stable over a range of $\mathrm{pH}$ and temperature, and have a high exchange capacity. When the waste stream contacts a bed of resin beads, hazardous ions are exchanged for the nonhazardous ions on the surface of the resin.' Hazardous ions near the resin are preferentially adsorbed to the surface of the resin, removing the hazardous ion from the waste stream (Rosengrant and Lopez 1991).

The main applications of ion exchange are for water purification and removing heavy metals and metal-cyanide complexes from dilute wastewater streams. The upper concentration limit for metals is about $2,500-4,000 \mathrm{mg} / \mathrm{L}$. Higher concentrations result in more rapid exhaustion of the resin and high regeneration costs. To avoid plugging of the resin, suspended solids should not exceed $50 \mathrm{mg} / \mathrm{L}$ (EPA 1985).

Oxidation. Chemical oxidation is a treatment technology in which contaminants are oxidized. It is used mainly for detoxifying cyanide and for treating dilute waste streams containing organics that can be oxidized (aldehydes, mercaptans, phenols, benzidine, unsaturated acids, and some pesticides). It can also be used to change the oxidation state of metallic compounds, such as arsenic, to valences that are less soluble or less toxic. Common oxidizing agents are chlorine and chlorine-containing compounds (calcium or sodium hypochlorite), ozone, potassium permanganate, and hydrogen peroxide (Rosengrant and Lopez 1991).

Chlorine and chlorine-containing compounds are the most widely used disinfectants for water and wastewater. Chlorine oxidizes a variety of compounds, including ammonia, cyanide, sulfide, and mercaptans. Ozone is an effective oxidizing agent for treating organic compounds and for oxidizing cyanide to cyanate and ultimately to $\mathrm{CO}_{2}$ and nitrogen compounds. Ultraviolet radiation can be used to accelerate the rates of ozonation. Potassium permanganate and hydrogen peroxide are used to oxidize phenol, sulfide, and cyanide (EPA 1985). 
Reduction. Chemical reduction is the addition of a reducing agent that lowers the oxidation state of a compound to reduce toxicity or solubility or to transform it to a form that can be disposed of more easily. Reduction can be carried out in a batch or continuous process. Treated wastewater is discharged to a mixer-clarifier, where a flocculent may be added to improve settling. The overflow from the clarifier can then be discharged to a sewer, while the remaining solids must be collected in a holding tank for dewatering and further treatment before disposal (Palmer et al. 1988).

Chemical reduction is used to reduce hexavalent chromium and selenate ions to the less soluble trivalent chromium ion and elemental selenium. It is also used to reduce mercury and lead ions and to treat wastes produced by oxidation. The chemicals most commonly used as reducing agents include $\mathrm{SO}_{2}$, sodium metabisulfite, sodium bisulfite, ferrous sulfate, and sodium borohydride. Other reducing agents that can be used for wastewater treatment are hydrazine, aluminum, zinc, and formaldehyde (Palmer et al. 1988).

\subsection{SOIL CONTAMINATION}

Information about the types and concentrations of chemical contaminants and how they are distributed through the soil is essential when soil treatment technologies are being selected. In order to present technologies that have been proven effective at a relatively low cost, the only technologies discussed here are those that the EPA has determined to be presumptive remedies. A presumptive remedy is a technology that the EPA believes will generally be the most appropriate on the basis of its past experience. The EPA has also determined that when presumptive remedies are used, the data collection effort and the detailed analysis can be limited, thereby streamlining the efforts and lowering the costs. The contaminants are categorized into three groups: organic compounds, inorganic compounds, and petroleum hydrocarbons.

\subsubsection{Organic Compounds}

\subsubsection{Soil Vapor Extraction}

An in-situ waste treatment technology, SVE is used to remove VOCs from unsaturated soils. This technology is also referred to as vacuum extraction, soil venting, aeration, enhanced volatilization, and in-situ volatilization. A typical SVE system is consists of a network of production wells, monitoring wells, emission control devices, and high-vacuum pumps or blowers. The vacuum pump system is used to apply a vacuum through production wells. The wells are drilled through the contaminated soil zone to a depth just above the water table; they are tightly sealed at the soil surface and connected to the vacuum pumps. The subsurface vacuum created by the vacuum pumps pulls VOC-laden vapor through the subsurface into the production wells. The air flow rate required to 
create a vacuum in the production wells ranges from 0.1 to $4.3 \mathrm{~m}^{3} / \mathrm{min}$ ( 3 to $150 \mathrm{ft}^{3} / \mathrm{min}$ ). Fresh air from the surface replaces the extracted vapor in the unsaturated soil.

As contaminants are drawn off, more VOCs go into the vapor phase, regain equilibrium, and are drawn off by the vacuum. The vacuum pumps and production wells are joined to a vapor/water separator by a manifold. The vapor is typically treated by activated carbon, catalytic oxidation, or an afterburner and is vented to the atmosphere. Any VOCs remaining in the water are stripped and treated or recovered.

One variation of the SVE technology involves groundwater dispersion systems combined with air stripping. This method increases the volume of unsaturated soil while volatilizing VOCs from the water. The system uses blowers and a series of air injection and extraction wells. Fresh air, heated air, or steam is forced down the injection wells, and VOC-contaminated air is withdrawn through the extraction wells and treated. This process is sometimes referred to as in-situ air stripping and has been demonstrated for treating a portion of a large contaminated plume (Schroeder et al. 1992).

\subsubsection{Bioremediation}

As discussed in Section 4.2 on water pollution, bioremediation refers to a range of processes that rely on microbial degradation of organic contaminants. It can be used to treat soil and sediment as well as liquids.

The effectiveness of all types bioremediation is influenced by several parameters, including oxygen availability, temperature, $\mathrm{pH}$, nutrient content, moisture content, total organic carbon, oxidation/reduction potential, and the absence of high concentrations of inhibiting compounds in the contaminated media. Other characteristics such as permeability, porosity, and particle size and distribution must be known to determine the procedures necessary for adequate delivery of nutrients or oxygen to the waste media and for movement of the microorganisms.

Biodegradation can take place under aerobic or anaerobic conditions, and the requirements of the ex-situ bioremediation technology depend on which of these conditions exists. Aerobic bioremediation requires the presence of molecular oxygen, because the primary mechanism of contaminant removal is oxidation, and molecular oxygen serves as the oxidant. The result is the transformation of organic contaminants into $\mathrm{CO}_{2}$ and other inert products and the generation of biomass. For conventional aerobic treatment, the optimal temperature is $20^{\circ}$ to $25^{\circ} \mathrm{C}$.

Anaerobic bioremediation involves microbial decomposition in the absence of oxygen. The result is the transformation of organic contaminants into $\mathrm{CO}_{2}$ and $\mathrm{CH}_{4}$ and the generation of biomass. The optimal temperature can be either $35^{\circ} \mathrm{C}$ (mesophilic) or $55^{\circ} \mathrm{C}$ (thermophilic), 
depending on the microorganisms (Bhattacharya 1992). Most organisms require a neutral $\mathrm{pH}$ for optimal growth.

\subsubsection{Incineration}

Incineration is the application of heat to wastes or contaminated materials to destroy organic contaminants by combustion or cracking. Incineration results in emissions of $\mathrm{CO}, \mathrm{CO}_{2}$, water vapor, sulfur oxides, hydrogen halides, and ash. Incompletely burned hydrocarbons may also be produced. The effective operating temperature ranges from $650^{\circ}$ to $980^{\circ} \mathrm{C}\left(1,200^{\circ}\right.$ to $\left.1,800^{\circ} \mathrm{F}\right)$. Common types of incinerators include rotary kilns, liquid injection furnaces, multiple hearth incinerators, and fluidized-bed incinerators.

An incinerator consists of a feed system, a combustion chamber, an ash collection and removal system, and an air pollution control system. Typical air pollution control components include baghouse filters (for particulate removal), packed-bed or plate tower absorbers (for acid gas removal), mist eliminators, venturi scrubbers (for particulate and acid gas removal), quench chambers for gas cooling and conditioning, and a stack through which the treated gases are vented to the atmosphere (Rosengrant and Lopez 1991).

The prirnary advantage of incineration is that it achieves significant volume reduction and maximum destruction of organic wastes - up to $99.99999 \%$ for volatiles and $99.99 \%$ for semivolatiles and nonvolatile organics. However, incinerators are not effective for treating wastes that contain mainly inorganic or radioactive contaminants. Also, the final waste form is stabilized as ash for further treatment or disposal. Some metals may be oxidized, whereas others may remain in the ash, exit gases, or particulates. The relative amount of each metal found in the ash or exit gas depends on the volatility of the metal or its combustion products at the incinerator's operating temperature.

Many types of incinerators are used to destroy waste, including multiple hearth incinerators, liquid injection furnaces, fluidized-bed incinerators, power generation boilers, flares, and afterburners.

The condition of the waste material before entering the combustion chamber must be identified and carefully controlled to obtain satisfactory combustion. If the waste is too wet to burn satisfactorily, it may be dewatered before burning by means of filter presses or driers. 


\subsubsection{Excavation and Dredging}

Conventional excavation and dredging methods involve the removal of contaminated solids or sludges by traditional earth-moving equipment such as loaders, scrapers, bulldozers, backhoes, draglines, clamshells, and hydraulic dredges. The successful application of excavation depends on proper site characterization to identify limiting factors. Limiting factors include the presence of surface structures, underground utilities or pipes, drums, tanks, other debris, large boulders or rocks, radioactive materials, hazardous waste, explosives, or contaminants that could release gaseous emissions (IT Corporation 1991). In addition, site characterization must define the soil type and the soil water content before the appropriate type of excavation can be identified.

The quantity and characteristics of the waste (i.e., contaminant types and concentrations), the physical properties of the waste, and the depth of contamination are principal parameters considered in selecting excavation technologies. Table 14 identifies some conventional excavation techniques.

\subsubsection{Petroleum Hydrocarbons}

\subsubsection{Thermal Desorption}

Thermal desorption involves the heating of soil, sludge, or other wastes in a reactor to temperatures that are high enough to desorb organics but are below those needed for incineration. A carrier gas moves over the heated soil and carries off water and desorbed organics to a gas treatment system, where the organics and other contaminants are removed and the cleaned carrier gas is recycled. Thermal desorption has been used to treat soils contaminated with petroleum hydrocarbons, PCBs, polycyclic aromatic hydrocarbons, pesticides, and volatile and semivolatile organics. This technique can also be used to vaporize mercury from soil (PNL 1992; EPA 1992).

Several types of full-scale desorption units are available commercially. Some can be adjusted to remove mercury. All units are transportable and either skid-mounted or mounted on tractor-trailer beds (EPA 1992). Capacities of commercially available, full-scale thermal desorbers range from $2.5-6.0 \mathrm{t} / \mathrm{h}$ to $70-90 \mathrm{t} / \mathrm{h}$.

The thermal desorption process typically heats the soil or sludge to temperatures ranging from $170^{\circ}$ to $440^{\circ} \mathrm{C}\left(300^{\circ}\right.$ to $\left.800^{\circ} \mathrm{F}\right)$ for 15 minutes to 5 hours. In some units, the soil temperature is raised in stages; at each stage, the temperature is chosen so as to maximize desorption of a specific group of compounds. The hot gases and solids exiting the drier are quenched with water to reduce their temperature and minimize dust emissions. The treated solids are stored temporarily, pending 
TABLE 14 Conventional Excavation Techniques

\begin{tabular}{|c|c|c|c|c|c|c|}
\hline $\begin{array}{l}\text { Equipment } \\
\text { Type }\end{array}$ & $\begin{array}{l}\text { Excavation } \\
\text { Application }\end{array}$ & $\begin{array}{l}\text { Possibility of } \\
\text { Excavating from an } \\
\text { Uncontaminated } \\
\text { Working Area }\end{array}$ & $\begin{array}{c}\text { Equipment } \\
\text { Capacity } \\
\left(\mathrm{yd}^{3}\right)\end{array}$ & $\begin{array}{c}\text { Applicable } \\
\text { Material } \\
\text { Conditions } \\
\end{array}$ & $\begin{array}{l}\text { Depth of } \\
\text { Excavation } \\
\text { Limits } \\
\end{array}$ & $\begin{array}{c}\text { Typical } \\
\text { Production Rate } \\
\left(\mathrm{yd}^{3} / 8 \text {-h day) }\right.\end{array}$ \\
\hline Loader & $\begin{array}{l}\text { Free face or mass } \\
\text { excavation }\end{array}$ & No & $1-10$ & $\begin{array}{l}\text { Dry or damp soils, } \\
\text { blasted rock }\end{array}$ & Surficial & $200-2,000$ \\
\hline Scraper & Mass excavation & No & $15-50$ & $\begin{array}{l}\text { Dry soils, } \\
\text { overburden }\end{array}$ & Surficial & $500-1,200$ \\
\hline Bulldozer & $\begin{array}{l}\text { Slot dozing, loader } \\
\text { support, spreading, } \\
\text { push scraper }\end{array}$ & No & $\begin{array}{c}\text { Not } \\
\text { applicable }\end{array}$ & Dry or damp soils & Surficial & $200-1,000$ \\
\hline Loader/backhoe & $\begin{array}{l}\text { Free face or vertical } \\
\text { trenching }\end{array}$ & Yes & $0.25-1.5$ & Dry or wet soils & $12-15 \mathrm{ft}$ & $50-120$ \\
\hline Backhoe & $\begin{array}{l}\text { Free face or vertical } \\
\text { trenching }\end{array}$ & Yes & $0.5-3.5$ & Dry or wet soils & $15-30 \mathrm{ft}$ & $150-1,000$ \\
\hline $\begin{array}{l}\text { Dragline or } \\
\text { clamshell }\end{array}$ & $\begin{array}{l}\text { Free face or vertical } \\
\text { trenching }\end{array}$ & Yes & $0.5-8$ & Dry or wet soils & $\begin{array}{l}\text { Unlimited for } \\
\text { clamshell, boom } \\
\text { reach for } \\
\text { dragline }\end{array}$ & $200-1,000$ \\
\hline
\end{tabular}

Source: Data from IT Corporation (1991). 
further treatment or disposal (PNL 1992; EPA 1991, 1992). Treatment of the gases depends on the contaminants desorbed and the desired end products.

\subsubsection{In Situ Biodegradation}

The overall process of in situ biodegradation is similar to ex situ bioremediation. The in situ bioremediation of soil typically involves percolation or injection of groundwater or uncontaminated water mixed with nutrients and saturated with dissolved oxygen. Sometimes acclimated microorganisms and an additional oxygen source, such as hydrogen peroxide, are added.

The main advantage of the in situ process is that it allows soil to be treated without being excavated. Also, it allows contaminated groundwater to be treated simultaneously with soil. Petroleum hydrocarbons can usually be degraded at a relatively low cost by stimulating indigenous microorganisms with or without nutrients. The disadvantages of the in situ process are that it generally requires a longer treatment time and it offers less certainty about the uniformity of treatment because it is difficult to monitor the process.

\subsubsection{Composting}

Composting is a controlled biological process in which microorganisms convert biodegradable contaminants into innocuous, stabilized by-products. The process typically occurs at an elevated temperature ranging from $120^{\circ}$ to $130^{\circ} \mathrm{F}$. The high temperature results from heat produced by the microorganisms during degradation of the organic material in the soil.

\subsubsection{Landfarming}

Landfarming is a bioremediation process in which microorganisms convert biodegradable contaminants into innocuous, stablized by-products. Contaminated soils, sediments, or sludges are placed on the ground surface, where they are periodically turned over or tilled to aerate the wastes. Factors that can limit the applicability and effectiveness of this process include the large amount of space required, the length of time required, the presence of volatile contaminants, and the fact that metal ions may be toxic to microbes and can leach into the ground.

Removal efficiencies are a function of contaminant type, concentration, soil type, temperature, moisture, waste loading rates, application frequency, aeration, and volatilization. In general, the higher the molecular weight of the compound, the more slowly it degrades. This is also true for more chlorinated or nitrated compounds. Contaminants successfully treated include No. 2 
and No. 6 fuel oils, JP-5 jet fuel, oily sludge, wood-preserving wastes, coke wastes, and some pesticides.

\subsubsection{Inorganic Compounds}

\subsubsection{Ex Situ Solidification and Stabilization}

Solidification is a treatment process in which a monolithic block of waste with high structural integrity is produced from excavated solid particulates, liquids, or sludge wastes. Contaminants are mechanically bonded by the solidification agents but do not interact chemically. Stabilization involves the addition of reagents that do react chemically with the waste material to limit the solubility or mobility of the contaminants. Solidification and stabilization techniques are often used together.

Several technologies, which differ in the types of reagents used for the treatment process, can be implemented to accomplish ex situ solidification and stabilization. These reagents include cement or lime, pozzolans, and organic binders. Gypsum, bentonites, zeolites, and a number of proprietary agents can also be used. Selecting a specific technology requires an understanding of both the chemical and physical properties of the contaminants and other waste constituents to be treated, as well as an understanding of the interaction of these constituents with the stabilization additives and the solidification and stabilization mechanism. These interactions are typically determined through extensive waste characterization and bench- and pilot-scale testing.

The ex situ solidification and stabilization technology has been widely used for disposal of low-level radioactive waste. Many vendors are studying, developing, or have available processes that are applicable to soil and sludge contaminated with hazardous waste (Noyes 1991). The solidification and stabilization technology can be applied to excavated soils by treating wastes in an engineered system (ex situ), or it can be applied to wastes in place (in situ). Ex situ solidification is

also commonly applied to sludge or slurry wastes generated as residual wastes from other processes (e.g., water treatment).

In the ex situ solidification and stabilization process, contaminated material is excavated and placed in an engineered treatment system, where additives are mixed with the waste matrix to form a solidified and stabilized product. The treated waste material can then be transported and disposed of or placed back at the site. In some cases, pretreatment of the targeted materials is needed to remove incompatible constituents for ex situ solidification and stabilization.

Site characterization is essential before implementing solidification and stabilization. Knowledge of site characteristics is necessary to identify (1) potential problem areas, such as the 
presence of contaminants that could interfere with the treatment process; (2) the extent of volatilization of contaminants expected, which would define off-gas treatment controls (for exposure of excavated wastes to the air and for organic binder systems); and (3) the quantity of dense soils, rocks, or cobbles that could hinder operation of the mixing equipment, thus necessitating more extensive pretreatment for size reduction. Bench- and pilot-scale treatability testing might also be required.

\subsubsection{Capping}

Capping is a containment technology in which contaminated materials are covered to (1) prevent their direct contact with receptors; (2) control infiltration; and (3) control emissions of hazardous substances, including the release of vapors or gases such as radon (emitted during the radioactive decay of uranium, radium, or thorium). Capping is also used to minimize the potential intrusion of animals or deep-rooted plants into the waste.

Several cap designs and materials can be used. The cap design is specific to the type of waste to be covered, local climate, hydrogeological conditions, availability of materials, and intended use of the capped area. Cap designs vary from single-layer gravel or soil covers to multilayered covers as specified by the EPA for Resource Conservation and Recovery Act (RCRA) hazardous wastes (Code of Federal Regulations, Title 40, Part 264). A minimum top slope of $2 \%$ is required.

\subsubsection{Excavation and Dredging}

Excavation and dredging, as discussed in Section 4.3.1.4, are also presumptive remedies for inorganic contamination. Conventional excavation and dredging methods involve the removal of contaminated solids or sludges by traditional earth-moving equipment such as loaders, scrapers, bulldozers, backhoes, draglines, clamshells, and hydraulic dredges. The successful application of excavation depends on proper site characterization to identify limiting factors. Limiting factors include the presence of surface structures, underground utilities or piping, drums, tanks, other debris, large boulders or rocks, radioactive materials, hazardous waste, explosives, or contaminants that could release gaseous emissions (IT Corporation 1991). In addition, site characterization must define the soil type and the soil water content before the appropriate type of excavation equipment can be identified. 


\section{COSTS OF POLLUTION CONTROLS IN CHINA}

\subsection{AIR POLLUTION}

Since the largest source of air pollution in China is coal combustion, controlling emissions from coal-fired utility and industrial boilers would make the greatest impact on air quality. The three major pollutants arising from coal combustion in utility and industrial boilers are $\mathrm{SO}_{2}, \mathrm{NO}_{\mathrm{x}}$, and particulates. It is proposed that either of two strategies be used to control these three pollutants.

- The first strategy would control air emissions in accordance with the U.S. 1970 CAA. This means that all utility and industrial boilers installed after 1971 with capacities greater than $73 \mathrm{MW}$ could emit no more than $1.2 \mathrm{lb}$ of $\mathrm{SO}_{2}, 0.7 \mathrm{lb}$ of $\mathrm{NO}_{\mathrm{x}}$, and $0.1 \mathrm{lb}$ of particulates per $10^{6} \mathrm{Btu}$.

- The second strategy would control pollutants in accordance with the 1970 $\mathrm{CAA}$ and, in addition, would further control $\mathrm{SO}_{2}$ emissions by requiring FGDs on boilers with capacities greater than $100 \mathrm{MW}$.

The following sections will discuss the technologies and costs associated with meeting the requirements of these two strategies.

\subsubsection{Strategy 1}

The emission targets in this strategy could be achieved by employing three control technologies: coal cleaning, low-NO $\mathrm{N}_{\mathrm{x}}$ burners, and particulate control. Coal cleaning could be used extensively to meet the emission standards. It would be particularly effective in reducing pollution from industrial boilers, because the vast majority of industrial boilers are small and fall below the 73-MW threshold that would mandate the installation of controls. There are more than 430,000 boilers in China, producing 1.8 billion $\mathrm{lb}$ of steam per hour (h). Since more than half of these boilers have a steam production capacity of $8,000 \mathrm{lb} / \mathrm{h}$ or less (Siddiqi et al. 1994), the majority of industrial boilers have an electrical capacity rating of less than $2 \mathrm{MW}$ and would not be required to install pollution controls according to the proposed standard. For purposes of this analysis, it is assumed that all of China's industrial boilers fall below the 73-MW threshold. (The availability of a more detailed industrial boiler inventory would make it possible to determine the exact number of boilers requiring pollution controls.) Since industrial boilers consume $50 \%$ of the coal in China, they are a very large source of pollution that would be totally uncontrolled.

Simple physical coal cleaning could reduce $\mathrm{SO}_{2}$ emissions by $10-30 \%$ and particulate emissions by up to $60 \%$ (DOE 1994). If it is assumed that the average sulfur content of run-of-mine 
Chinese coal is $1.2 \%$, cleaned coal would have a sulfur content as low as $0.84 \%$, which would result in an $\mathrm{SO}_{2}$ emission level that would be only $8 \%$ higher than the standard mandates. Consequently, additional sulfur removal might not be needed unless some plants were to use coal with a higher sulfur content. In addition, because uncontrolled particulate emissions from Chinese coal could be as high as $15 \mathrm{lb} / 10^{6}$ Btu (assuming an ash content of $24 \%$ ), cleaned coal could reduce these emissions to $4.8 \mathrm{lb} / 10^{6} \mathrm{Btu}$. Although coal cleaning alone would not be sufficient to meet the standard for particulate emissions, it would go a long way toward reducing them when compared with uncontrolled coal combustion. It is estimated that if all coal (at the present rate of consumption) were cleaned before combustion, particulate emissions could be reduced by 6.0-7.1 million t/yr. Furthermore, if coal cleaning could reduce the sulfur content of coal by $30 \%, \mathrm{SO}_{2}$ emissions could be reduced by $1.8-2.4$ million $t / y r$.

Currently, only about 196 million $t$ of the coal produced in China undergoes any cleaning process (Bhatti et al. 1994). Coal produced for domestic combustion amounts to about 1.2 billion $t$, meaning that approximately 1 billion $t$ are not cleaned. It has been estimated that the cost to clean coal is about \$2-\$3/t, including annual capital charges and O\&M costs (IEA Coal Research 1993). Therefore, an annual investment of about $\$ 2-3.5$ billion would be required to build and operate enough coal cleaning capacity for all of the coal presently produced for domestic consumption in China. Naturally, this cost would increase by the amount of increase in coal production each year. Table 15 summarizes the costs and emission reductions associated with the emission controls proposed for this strategy.

Using clean coal would have a number of other benefits in addition to reduced $\mathrm{SO}_{2}$ and particulate emissions. These benefits include reduced slagging and fouling of boilers, increased boiler efficiency, and decreased waste and ash disposal from boiler operation. In addition to these operational improvements, the O\&M costs of boilers would be reduced. Furthermore, if the coal were to be cleaned at or near the mine, transportation costs and the associated pollution from transporting coal could be greatly reduced, because a great deal of unwanted material such as dirt, rocks, and other inert matter would not be needlessly transported to the end user. Also, having an extensive coal cleaning capability would make Chinese coal more attractive for export to other countries, thereby increasing foreign exchange for China.

Since use of clean coal would do little to reduce $\mathrm{NO}_{\mathrm{x}}$ emissions, some coal-fired boilers installed after 1971 would have to have some form of $\mathrm{NO}_{x}$ control. Again, because most industrial boilers fall below the 73-MW threshold, it is assumed that $\mathrm{NO}_{\mathrm{x}}$ controls would be applied only to utility boilers. (As noted earlier, if a more detailed inventory of industrial boilers were available, the number of boilers requiring $\mathrm{NO}_{\mathrm{x}}$ controls could be easily determined.) Since most utility boilers have uncontrolled $\mathrm{NO}_{x}$ emissions of $1.5 \mathrm{lb} / 10^{6}$ Btu or less (NAPAP 1990), a control device to reduce these emissions by about $50 \%$ would be needed to meet the proposed standard. A combustion modification using low- $\mathrm{NO}_{x}$ burners could be implemented. Low- $\mathrm{NO}_{\mathrm{x}}$ burners retrofit on pulverized coal boilers (which make up most of the utility plant boilers) could reduce $\mathrm{NO}_{\mathrm{x}}$ emissions by at least 
TABLE 15 Strategy 1: Cost and Pollution Reduction Achieved

\begin{tabular}{|c|c|c|c|c|c|}
\hline \multirow[b]{2}{*}{ Activity } & \multirow[b]{2}{*}{$\begin{array}{l}\text { Total Retrofit } \\
\text { Cost }(1995 \$)\end{array}$} & \multirow[b]{2}{*}{$\begin{array}{c}\text { Annual Cost } \\
(1995 \$)\end{array}$} & \multicolumn{3}{|c|}{$\begin{array}{l}\text { Pollution Reduction } \\
\qquad\left(10^{6} \mathrm{t} / \mathrm{yr}\right)\end{array}$} \\
\hline & & & $\mathrm{SO}_{2}$ & $\mathrm{NO}_{\mathrm{x}}$ & Particulates \\
\hline Coal cleaning ${ }^{\mathrm{a}}$ & -- & 2.9 billion & $1.8-2.4$ & $N A^{b}$ & $6.0-7.1$ \\
\hline Low-NO burners $^{c}$ & 0.67 billion & 37 million & NA & 0.9 & NA \\
\hline Particulate control $^{\mathrm{d}}$ & 2.7 billion & 277 million & NA & NA & $0.4-0.5$ \\
\hline Total & 3.4 billion & 3.2 billion & $1.8-2.4$ & 0.9 & $6.4-7.6$ \\
\hline
\end{tabular}

a Assumes all coal produced for domestic combustion is cleaned.

b $\mathrm{NA}=$ not applicable.

c Installed only on utility coal-fired boilers (greater than $73 \mathrm{MW}$ ) that currently lack low-NO $\mathrm{x}$ burners.

d Installed only on utility coal-fired boilers with a capacity between 73 and $200 \mathrm{MW}$. All larger plants are assumed to already have ESPs.

$50 \%$ and possibly as much as $75 \%$. In most cases, low-NO $\mathrm{N}_{\mathrm{x}}$ burners can be easily retrofit on pulverized coal boilers for relatively low capital and $O \& M$ costs (i.e., $\$ 12 / \mathrm{kW}$ and $0.1 \mathrm{mill} / \mathrm{kWh}$, respectively [NAPAP 1990]). If greater $\mathrm{NO}_{x}$ reduction were to be needed or if low-NO ${ }_{x}$ burners could not be installed on a particular plant, a postcombustion technology such as SCR or SNCR could be applied. However, although these technologies have larger $\mathrm{NO}_{\mathrm{x}}$ reduction efficiencies, the life cycle costs can be much greater.

The Chinese have recently instituted a program to install low $\mathrm{NO}_{x}$ burners of a Chinese design on coal-fired utility boilers (Xu 1995). Currently, 64 utility plants have these low- $\mathrm{NO}_{\mathrm{x}}$ burners installed. This amounts to about $21 \%$ of the plants that could use these burners. On the basis of this information, it was determined that $\mathrm{NO}_{x}$ controls would still be required on $56 \mathrm{GW}$ of utility coal-fired capacity installed between 1971 and 1995 . The capital cost to retrofit all eligible utility power plants with low- $\mathrm{NO}_{x}$ burners would be about $\$ 670$ million. In addition, the annual cost for O\&M of these burners (exclusive of capital carrying charges) would be about $\$ 37$ million (assuming a capacity factor of $75 \%$ for all plants). Installing low- $\mathrm{NO}_{\mathrm{x}}$ burners on the remaining utility boilers would reduce $\mathrm{NO}_{x}$ emissions by an additional 0.9 million t/yr. The costs and emission reductions associated with this control technology are summarized in Table 15 .

Finally, although coal cleaning could go a long way toward reducing particulate emissions, it alone would not bring coal-fired boilers into compliance with the proposed standard. An additional control technology would be required. Again, because most industrial boilers fall below the 73-MW 
threshold, it is assumed that particulate controls will be applied only to utility boilers. (As noted earlier, if a more detailed inventory of industrial boilers was available, the number of boilers needing particulate controls could be easily determined.)

Since Chinese coal has a very high ash content, typically about $24 \%$, uncontrolled particulate emissions in utility coal-fired boilers can be as high as $15 \mathrm{lb} / 10^{6} \mathrm{Btu}$. Currently, utility plants greater than $200 \mathrm{MW}$ already use ESPs to control particulates (Xu 1995). However, plants between 73 and $200 \mathrm{MW}$ have no particulate controls. Consequently, these plants would need some form of particulate control to comply with the proposed regulation. The required removal efficiency could be achieved by installing either a baghouse or ESP into the flue gas stream. The particulate removal efficiency of these units is typically about $98 \%$. The choice of technology would be determined in part by space requirements and other site-specific and plant-specific factors.

It is estimated that utility plants with capacities between 100 and $200 \mathrm{MW}$ installed from 1971 to 1995 total about $42 \mathrm{GW}$. For purposes of this analysis, a generic unit cost is used for both capital and O\&M costs for installing either a baghouse or ESP. The capital cost to install a particulate control unit is estimated to be about $\$ 57 / \mathrm{kW}$; the O\&M cost is estimated to be about $\$ 5.9 / \mathrm{kW}$ per year (adapted from Shoat et al. 1993). The capital cost to retrofit all eligible plants with particulate controls would be about $\$ 2.7$ billion. In addition, the annual cost for O\&M of these units (exclusive of capital carrying charges) would be about $\$ 277$ million (assuming a capacity factor of $75 \%$ for all plants). It is also estimated that retrofitting these plants with particulate controls would reduce emissions by $0.4-0.5$ million $t / y r$. The costs and emission reductions associated with this control technology are summarized in Table 15.

\subsubsection{Strategy 2}

The second strategy proposes controlling pollutants in accordance with the $1970 \mathrm{CAA}$ but further controlling $\mathrm{SO}_{2}$ emissions by requiring $\mathrm{FGDs}$ on boilers with capacities greater than $100 \mathrm{MW}$. Coal cleaning, low- $\mathrm{NO}_{\mathrm{x}}$ burners, and particulate controls would continue to be a part of this strategy. As noted earlier, since the vast majority of industrial boilers are below the capacity threshold, FGDs would be applied only to utility coal-fired boilers. (If a more detailed inventory of industrial boilers were available, the number of industrial boilers requiring $\mathrm{SO}_{2}$ controls could be easily determined.) It should be noted that FGDs have an $\mathrm{SO}_{2}$ removal efficiency in excess of $90 \%$. Currently, only two utility plants in China (having an installed capacity of $720 \mathrm{MW}$ ) have FGDs. From two references (Ministry of Energy 1992; Li and Johnson 1994), it is estimated that FGDs would be required on $71 \mathrm{GW}$ of utility coal-fired capacity installed between 1971 and 1995. It is assumed that the cost to install an FGD unit averages about $\$ 200 / \mathrm{kW}$ (ICAC 1994), while the O\&M costs of such a unit are about 1.5 mills $/ \mathrm{kWh}$ (Weilert and Dyer 1995). Consequently, the capital cost to retrofit all eligible coal-fired utility power plants installed between 1971 and 1995 with an FGD would be about $\$ 14.2$ billion. In addition, the annual cost for O\&M of these units (exclusive of 
capital carrying charges) would be about $\$ 705$ million (assuming a capacity factor of $75 \%$ for all plants). Installing an FGD on all utility power plants with a capacity of more than $100 \mathrm{MW}$ would reduce $\mathrm{SO}_{2}$ emissions by about 3.0 million t/yr (assuming a 95\% removal efficiency). Table 16 summarizes the costs and emission reductions associated with this strategy.

Furthermore, depending on the type of FGD system used, the slag and sulfur by-products generated by the process could be used to make either gypsum (for construction materials such as wallboard) or chemical feedstock (for fertilizer). Consequently, the money made from the sale of these products could be used to offset the costs of installing and maintaining the FGD system.

\subsubsection{Options for Future Generating Capacity}

Coal will continue to account for a large portion of new power plant capacity in the future. Table 17 shows the total installed power plant capacity that will be required in the future, categorized by fuel type. Coal is estimated to account for $65 \%$ of the total installed capacity in 2000 and $60 \%$ in 2010. By $2000,58 \mathrm{GW}$ of additional coal-fired capacity will be required, and by $2010,125 \mathrm{GW}$

TABLE 16 Strategy 2: Cost and Pollution Reduction Achieved

\begin{tabular}{|c|c|c|c|c|c|}
\hline \multirow[b]{2}{*}{ Activity } & \multirow[b]{2}{*}{$\begin{array}{l}\text { Total Retrofit } \\
\text { Cost }(1995 \$) \\
\end{array}$} & \multirow[b]{2}{*}{$\begin{array}{c}\text { Annual Cost } \\
(1995 \$)\end{array}$} & \multicolumn{3}{|c|}{$\begin{array}{l}\text { Pollution Reduction } \\
\qquad\left(10^{6} \mathrm{t} / \mathrm{yr}\right)\end{array}$} \\
\hline & & & $\mathrm{SO}_{2}$ & $\mathrm{NO}_{\mathrm{x}}$ & Particulates \\
\hline Coal cleaning $^{\mathrm{a}}$ & -- & 2.9 billion & $1.8-2.4$ & $N A^{b}$ & $6.0-7.1$ \\
\hline Low-NO burners $^{\mathrm{c}}$ & 0.67 billion & 37 million & $\mathrm{NA}$ & 0.9 & $\mathrm{NA}$ \\
\hline Particulate control ${ }^{d}$ & 2.7 billion & 277 million & NA & NA & $0.4-0.5$ \\
\hline $\mathrm{FGD}^{\mathrm{e}}$ & 14.2 billion & 705 million & 3.0 & $\mathrm{NA}$ & NA \\
\hline Total & 17.6 billion & 3.9 billion & $4.8-5.4$ & 0.9 & $6.4-7.6$ \\
\hline \multicolumn{6}{|c|}{ a Assumes all coal produced for domestic combustion is cleaned. } \\
\hline \multicolumn{6}{|c|}{ b $\mathrm{NA}=$ not applicable. } \\
\hline \multicolumn{6}{|c|}{$\begin{array}{l}\text { Installed only on utility coal-fired boilers (greater than } 73 \mathrm{MW} \text { ) that currently lack low- } \\
\mathrm{NO}_{\mathrm{x}} \text { burners. }\end{array}$} \\
\hline \multicolumn{6}{|c|}{$\begin{array}{l}\text { Installed only on utility coal-fired boilers with a capacity between } 73 \text { and } 200 \mathrm{MW} \text {. All } \\
\text { larger plants are assumed to already have ESPs. }\end{array}$} \\
\hline \multicolumn{6}{|c|}{ e Installed on all utility coal-fired power plants greater than $100 \mathrm{MW}$. } \\
\hline
\end{tabular}


TABLE 17 Installed Generating Capacity by Fuel Type and Year

\begin{tabular}{|c|c|c|c|c|c|c|}
\hline \multirow[b]{2}{*}{ Fuel } & \multicolumn{2}{|c|}{1995} & \multicolumn{2}{|c|}{2000} & \multicolumn{2}{|c|}{2010} \\
\hline & GW & $\begin{array}{c}\text { Share } \\
(\%)\end{array}$ & GW & $\begin{array}{c}\text { Share } \\
(\%)\end{array}$ & GW & $\begin{array}{c}\text { Share } \\
(\%)\end{array}$ \\
\hline Total & 207 & 100 & 300 & 100 & 530 & 100 \\
\hline Coal & 137 & 66 & 195 & 65 & 320 & 60 \\
\hline Hydro & 52 & 25 & 75 & 25 & 140 & 26 \\
\hline Oil and gas & 16 & 8 & 20 & 7 & 30 & 6 \\
\hline Nuclear & 1 & 1 & 7 & 2 & 35 & 7 \\
\hline Other & 1 & 1 & 3 & 1 & 5 & 1 \\
\hline
\end{tabular}

Source: Adapted from $\mathrm{Li}$ and Johnson (1994).

of additional coal-fired capacity will be required ( $\mathrm{Li}$ and Johnson 1994). Consequently, there will be a great need for coal-fired technologies that can meet stringent emission control standards. Clean coal technologies such as FBC and IGCC can meet even the most stringent control standards. Removal efficiencies for $\mathrm{FBC}$ units exceed $90 \%$ for $\mathrm{SO}_{2}$, are $50-90 \%$ for $\mathrm{NO}_{\mathrm{x}}$, and are greater than 95\% for particulates; removal efficiencies for IGCC units exceed $98 \%$ for $\mathrm{SO}_{2}$, are $70-95 \%$ for $\mathrm{NO}_{x}$, and are $98 \%$ for particulates. Furthermore, both FBC and IGCC systems can boost power generation efficiencies to well above $40 \%$, compared with the $30-35 \%$ efficiencies of conventional coal-fired technology (DOE 1994).

IGCC technology is also very effective in removing trace metals such as mercury and lead and VOCs from coal. This feature will be very advantageous if the regulations that are eventually drafted limit these emissions. In addition, the slag and sulfur by-products of the IGCC process can be sold as construction material and chemical feedstocks, respectively, thereby reducing the overall cost of this technology.

Finally, the cost of these clean coal technologies is generally only about $\$ 100-\$ 200 / \mathrm{kW}$ more than those of conventional coal-fired plants with emission controls for $\mathrm{SO}_{2}, \mathrm{NO}_{\mathrm{x}}$, and particulates. This cost could be reduced further if China develops the capability to manufacture this technology in country. 


\subsection{WATER POLLUTION}

\subsubsection{Domestic Water}

In the United States, the average daily domestic (central) withdrawal is $118 \mathrm{gal}\left(0.43 \mathrm{~m}^{3}\right)$. The per-capita use per day is about $87 \mathrm{gal}\left(0.33 \mathrm{~m}^{3}\right)$. The difference is the result of delivery losses and other incidental uses. In China, the average per capita water use per day is about $20 \mathrm{gal}$ $\left(0.08 \mathrm{~m}^{3}\right)$, four times less than that of the United States (Corbitt 1990; van der Leeden 1990).

Treatment of drinking water generally includes filtration, coagulation, chlorination, and treatment with activated carbon. This treatment would provide $100 \%$ reduction in bacteria, $100 \%$ reduction in turbidity, color reduction to near zero, reduction of iron and manganese, and removal of taste and odor. The addition of chlorine is not essential for removal of bacteria; however, it provides $100 \%$ reduction in bacteria, reduces the bacterial load on filters, oxidizes organic matter, reduces odor, and reduces manganese concentration. The system cost information is based on the number of gallons processed per day. On the basis of available rates for packaged water treatment plants, a plant that would provide a city of 500,000 people would cost about $\$ 935,000$. The cost of this option assumes that the delivery system is already installed.

\subsubsection{Municipal and Industrial Wastewater}

The relative cost increase from primary to secondary treatment is about $200 \% / 10^{3}$ gal of wastewater treated. The relative cost increase from primary to tertiary treatment is about $350 \% / 10^{3}$ gal of water treated (Bond et al. 1974). On the basis of these statistics, the most cost-effective way to improve water quality would be to construct plants for the secondary treatment of domestic and industrial wastewater. The cost of secondary treatment ranges from 16 to 18 cents $/ 10^{3}$ gal. The cost of tertiary treatment ranges from 24 to 30 cents $/ 10^{3}$ gal. Costs are then calculated on the basis of the size of the population served.

Costs of constructing wastewater treatment facilities vary with the size of the unit required. The costs for a facility that treats $200,000,500,000$, and $800,000 \mathrm{gal} / \mathrm{d}$ are $\$ 544,000, \$ 1,500,000$, and $\$ 2,077,000$, respectively.

\subsubsection{Rural Water}

The costs for some of the options (hand-dug wells, infiltration galleries, spring capping, rainwater catchment) include costs for labor and materials. The cost of installing hand-pumps ranges from $\$ 13$ to $\$ 30$ per capita. 


\subsection{SOIL CONTAMINATION}

The costs of soil treatment technologies depend on a number of site-specific factors including the type of chemical, nature and extent of the area to be cleaned, soil type, and hydrogeology of the area. The cost of implementing treatment technologies is given per unit of soil treated. This cost is site-specific and is based on the size of the site, nature and extent of contamination, and hydrogeology of the site in question.

\subsubsection{Organic Compounds and Petroleum Hydrocarbons}

- Extracting vapor from soil costs $\$ 10-50 / \mathrm{m}^{3}$ ( $\$ 10-40 / \mathrm{yd}^{3}$ ) of soil. Pilot testing typically cost $\$ 10,000$ to $\$ 100,000$.

- Thermal desorption (low temperature) of soil costs $\$ 45-110 / t$ ( $\$ 40-100 /$ ton) of soil. Thermal desorption of clayey soils may approach a cost of $\$ 220 / \mathrm{t}$ $(\$ 200 /$ ton). Excavation of contaminated soil and replacement with the treated soil cost $\$ 6-11 / \mathrm{t}(\$ 5-10 /$ ton $)$.

- Incinerating soil costs $\$ 220-1,100 / \mathrm{t}$ ( $\$ 200-1,000 /$ ton). Incinerating soil contaminated with PCBs or dioxins costs $\$ 1,650-6,600 / t$ ( $\$ 1,500-6,000 /$ ton).

- Bioremediation costs $\$ 30-100 / \mathrm{m}^{3}\left(\$ 20-80 / \mathrm{yr}^{3}\right)$ of soil. Variables affecting the cost include the nature and extent of contamination, use of hydrogen peroxide or other augmentation, and hydrogeology of the site.

- Excavation/disposal is estimated to cost $\$ 300-510 / t$ ( $\$ 270-460 /$ ton) of soil, depending on the nature of the contaminants and method of excavation. This estimate would be different outside the United States because it includes the cost of disposal in a RCRA-permitted facility. Excavation and disposal are labor-intensive activities, with little potential for further automation.

\subsubsection{Inorganic Compounds}

- Oxidation/reduction costs $\$ 190-660 / \mathrm{m}^{3}\left(\$ 150-500 / \mathrm{yd}^{3}\right)$ of soil.

- Costs of cement-based stabilization technologies vary widely according to the reagents used, project size, and nature of the contaminants. In situ soil mixing costs an average of $\$ 50-80 / \mathrm{m}^{3}\left(\$ 40-60 / \mathrm{yd}^{3}\right)$ for shallow applications. Deeper applications cost $\$ 190-330 / \mathrm{m}^{3}\left(\$ 150-250 / \mathrm{yd}^{3}\right)$. 
- The cost of capping varies widely $\left(\$ 50-100 / \mathrm{yd}^{3}\right)$ depending on the design, materials, and purpose. 


\section{CONCLUSIONS}

Since its formation in 1949, the government of China has put a great deal of effort into creating a highly industrialized nation. Many of the government policies have been directed toward developing heavy industry through subsidies of cheap energy, minerals, water, and other resources provided to encourage growth in this sector. The legacy of these policies has been severe environmental contamination of the air, water, and soil systems, with its attendant deterioration of human health, in large portions of the country. The economic reforms of the past decade have intensified this situation. At the same time, greater contact with the industrialized western world has increased the awareness of the general population that air, water, and soil pollution are likely responsible for a significant number of the major ailments currently prevalent in China. These factors have provided the government with an impetus to enact programs and policies that attempt to provide environmental protection for its resources and human population.

The environmental situation in China today is, in some ways, similar to that faced by the United States and Western Europe during the 1930s through the 1950s. Therefore, China could learn from the experiences of the United States, avoiding its mistakes and following its successes to develop a comprehensive environmental protection program.

\subsection{AIR}

In China, the high rate of energy use, heavy reliance on coal as an energy source, dominance of the industrial sector in the economy, and absence of pollution control devices on utility and industrial plants together have resulted in extremely high concentrations of air pollutants, especially in and around urban centers. Levels of many air pollutants routinely are many times the limits recommended by the WHO and many times the levels that occur in cities in industrialized nations. These high levels of air pollutants are, in large part, responsible for the fact that respiratory disease is now the predominant cause of death in China. Alleviating this situation requires, at a minimum, the implementation and enforcement of air pollution control regulations for the main air pollutants, namely $\mathrm{SO}_{2}, \mathrm{NO}_{\mathrm{x}}$, ozone, and particulates. On the basis of U.S. experience in air pollution control, it appears that the most cost-effective strategy to address China's air pollution problems would be to follow the guidelines and requirements set forth in the $1970 \mathrm{CAA}$ of the United States. To achieve these objectives, a number of control technologies can be considered. Since the consumption of coal is the main source of air pollution in most of China, this report concentrates on those control options designed to reduce pollution caused by coal combustion.

Probably the most important air pollution control option that China should pursue is to clean most, if not all, of the coal used for domestic purposes. Coal cleaning can control both sulfur and particulate emissions, which are two of the most important pollutants emitted by coal 
combustion. Clean coal technology is especially important because a great deal of coal is used in small industrial boilers, and it is generally not cost-effective to control pollutants at the boiler level for very small units. By cleaning coal before combustion, sulfur emissions can be reduced by $10-30 \%$ and particulate emissions can be reduced by up to $60 \%$ in all coal boilers. This reduction could, in turn, reduce final $\mathrm{SO}_{2}$ emissions by up to 2.4 million t/yr and particulate emissions by up to 7.1 million t/yr. An annual investment of about $\$ 2.9$ billion would be required to build and operate enough coal cleaning capacity for all of the coal presently produced for domestic consumption in China.

Besides reducing air pollution, coal cleaning results in other operational and maintenance benefits, such as increased boiler efficiency, lower maintenance costs, and decreased ash and waste disposal. Furthermore, if coal is cleaned at or near the mine, transportation costs and the pollution associated with transportation can be greatly reduced, because such noncombustible material as dirt, rocks, and other inert material will not be transported to the end user. Also, Chinese coal will be more attractive for export to other countries if it has been cleaned, thereby increasing foreign exchange for China.

Since coal cleaning does not reduce $\mathrm{NO}_{\mathrm{x}}$ emissions, additional controls may be needed to reduce this pollutant. Combustion modifications, such as low- $\mathrm{NO}_{\mathrm{x}}$ burners, can be retrofitted onto pulverized-coal-fired utility boilers. This technology has relatively inexpensive capital and O\&M costs and is easily adaptable to almost any boiler firing system. Currently, China is adding low-NO burners to some of its utility plants. Given this experience, more low- $\mathrm{NO}_{\mathrm{x}}$ burners can be installed, depending on the requirements of the regulations. If all current coal-fired utility power plants $\left(>100 \mathrm{MW}\right.$ ) had low- $\mathrm{NO}_{\mathrm{x}}$ burners, $\mathrm{NO}_{\mathrm{x}}$ could be reduced by an additional 0.9 million $\mathrm{t} / \mathrm{yr}$.

In the future, more stringent regulations might be required to control air pollution in China. These requirements could involve the imposition of additional control technologies on large coalfired boilers to reduce $\mathrm{SO}_{2}$ and particulate emissions. Additional $\mathrm{SO}_{2}$ control could be achieved by retrofitting FGDs on large coal-fired boilers, particularly those that use high-sulfur coal. As FGD technology has matured, the costs of FGD units have come down (averaging now about $\$ 200 / \mathrm{kW}$ ), their removal efficiencies have improved, and their power consumption has been reduced. In the past, these were problem areas for FGDs. Furthermore, current FGDs produce by-products that do not need to be disposed of as waste but can be used as feedstocks for either the construction or chemical industries. If all utility coal-fired power plants ( $>100 \mathrm{MW}$ ) had $\mathrm{FGDs}, \mathrm{SO}_{2}$ emissions could be reduced by an additional 3.0 million $t / y r$ (if the coal fed into the plant had been cleaned).

Also, where needed, additional particulate control could be achieved by installing either a baghouse or an ESP in the flue gas stream. Their removal efficiencies are very high (typically $98 \%$ ), and their capital and O\&M costs are moderate. Installing particulate controls on coal-fired utility power plants between 73 and $200 \mathrm{MW}$ would reduce particulate emissions by an additional 
0.4-0.5 million t/yr (if power plants greater than $200 \mathrm{MW}$ already had particulate controls and the coal fed into the plant had been cleaned).

Finally, since China plans on making a large commitment to coal for future generating units, clean coal technologies, such as IGCC or FBC, should be considered. These units are about $\$ 100-200 / \mathrm{kW}$ more expensive than conventional coal-fired power plants with pollution controls, but they are much more efficient in removing $\mathrm{SO}_{2}, \mathrm{NO}_{\times}$and particulates (up to $98 \%$ removal efficiency). In addition, these technologies can boost power generation efficiencies over those achieved by conventional coal-fired technology. Also, the by-products of the process do not need to be disposed of as waste but can be used as feedstocks for either the construction or chemical industry. Furthermore, IGCC technology is effective in reducing other pollutants, such as trace metals and VOCs. If the development of air pollution regulations in China follows that of developed countries, these pollutants will likely be controlled in the future.

\subsection{WATER}

Contamination of water resources is also a serious problem in China. A large number of sources and activities contribute to the degradation of these resources. Approximately $80 \%$ of the wastewater produced from industrial processes, municipal wastes, and energy production and consumption activities is discharged untreated into waterways. This situation has led to a serious water pollution problem in China - less than $15 \%$ of the population have access to safe drinking water supplies. Levels of contaminants in major water systems are often many times the U.S. and WHO recommended limits. In addition, acid deposition and pollution of offshore waters have led to further contamination of water resources in China. Shortages of water are also common in this country. The mitigation of water contamination and water shortage problems in China could be most effectively carried out by following the lessons learned through the U.S. experience in water pollution control.

The basic strategy to address the water quality and quantity problems in China should focus on improving the existing pollution fee system. Such a strategy should include the (1) development of mass-flow levy formulas for pollutants, with fee schedules established on the basis of the costs of pollution control; (2) design of a pollution levy fund that considers institutional arrangements, technical assessment of loans, and priorities for using the fund; (3) design of an information management system for calculating fees and maintaining billing and receipts; and (4) consideration of practical issues of implementation (effluent monitoring, calculating and collecting fees, fund management). Resolution of these issues could remove the obstacles that are currently impeding improvement of water quality. Other provisions that have been successful in reducing contamination from municipal and industrial discharges in the United States include those that limit the ability of facilities to get exemptions from federal pollution control regulations, prohibit the violation of 
permits, or prevent the weakening of treatment requirements when industrial and municipal discharge permits are renewed or reissued.

The pollution control incentive provided by the Chinese levy system is weak because fees are small relative to the costs of implementing pollution control. For firms that pay discharge fees, the fees are typically less than $0.1 \%$ of the firm's total production value. By comparison, U.S. industry's environmental compliance costs are estimated to be slightly more than $1 \%$ of the total manufacturing costs. Higher fees could increase compliance. Also, because the fees and fines currently in place are often lower than the cost of operating and maintaining pollution control equipment, companies that do install such equipment have little incentive to operate it. If the EPB were more strongly supported by the government and if fees and fines were increased significantly, incentives for implementing pollution controls would be improved because more money would be available for loans for pollution control equipment and companies would have greater incentives to operate and maintain equipment once it was installed.

For wastewater, the costs and effectiveness of different levels of treatment in removing pollutants should be compared. It is estimated that primary treatment removes approximately 30 $40 \%$ of the pollutants present in the original wastewater. Secondary treatment removes approximately $90 \%$ of the original pollutants, while tertiary treatment removes more than $95 \%$ of the pollutants that were present in the original wastewater. In general, secondary treatment increases the percentage removal of BOD and suspended solids by approximately $100 \%$ when compared with primary treatment. Tertiary treatment removes another 5\% of the BOD and suspended solids remaining after secondary treatment. The relative cost increase from primary to secondary treatment is about $200 \% / 1,000$ gal of water treated, whereas the relative cost increase from primary to tertiary treatment is about $350 \% / 1,000$ gal of water treated. Therefore, the most cost-effective strategy for improving the quality of wastewater would be the construction of wastewater treatment plants that carry out secondary treatment of domestic and industrial wastewater. The cost of such secondary treatment would average approximately 16 to $18 \mathrm{cents} / 10^{3}$ gal. To this must be added the cost of construction of wastewater treatment facilities, which ranges from $\$ 544,000$ for a 200,000 -gal/d facility to $\$ 2,077,000$ for an 800,000 -gal/d facility.

The cost of providing safe drinking water to individuals would be considerably higher than the cost of treating wastewater. For a city of 500,000 that already has the infrastructure for distributing this water in place, the cost (i.e., cost of water treatment only) would be approximately $\$ 935,000$.

\subsection{SOIL}

The large population of China, China's high economic growth rate, and the reliance on industrial activities to fuel this growth have resulted in the production of large quantities of solid 
wastes. This burden on soil systems is further compounded by the degradation of these resources through land-use changes, agricultural activities, and mining, especially of coal. Erosion of topsoil and desertification have reached alarming levels in China over the past few decades. Some effort has been made to control desertification and erosion with the planting of a shelterbelt of trees known as the Great Green Wall of China. However, management of the increasing contamination of soil systems needs to be initiated and actively pursued as well. Remedies for controlling soil contamination include modifying activities to eliminate obvious sources of contamination and implementing available technologies to treat soil. As is the case for air and water pollution, China could benefit by following some of the strategies used by the United States in the early battle to address its soil contamination problems.

The approach used by the U.S. to manage solid wastes has been successful in controlling waste disposal, encouraging waste minimization, and promoting recycling. The permitting of treatment, storage, and disposal facilities is governed by the regulations set forth in the Resource Conservation and Recovery Act (RCRA) approved in 1976. One of the most effective components of this act is waste manifesting, which tracks wastes from the point of generation to disposal. This tracking process has assisted in controlling illegal dumping and improper disposal activities through the provision of a closed-loop accounting system for wastes. As a result, waste volumes have decreased, and the use of biodegradable materials, recycling, and reuse have increased. This act is made more effective in controlling waste disposal practices because it provides the EPA with the authority to identify and monitor activities of individual facilities and to impose fines and conditions on those that violate permit conditions.

Land disposal is considered the least-preferred option for disposal of solid wastes, for a number of reasons. One is that land disposal can pose risks to human health and the environment. Another is the shortage of available land suitable for disposal. In addition, the stability of wastes in terrestrial sites over the long term is questionable, and restoration of land disposal areas is expensive. The RCRA attempted to discourage land disposal of solid wastes through its land disposal restrictions provision. This provision has had the effect of forcing the development of new disposal technologies. In China, where land is much more scarce and land-use conflicts are much more serious than in the United States, land disposal presents even more of a problem. A similar provision restricting land disposal would alleviate some of the landfill and solid waste problems that China currently faces.

China has responded to some of its environmental problems by encouraging the growth of the environmental products industry through the establishment of an environmental products market and the creation of special parks for environmental protection industries to allow them to take advantage of economies of scale. The Chinese government could provide further incentives for the development of new waste disposal technologies by providing tax breaks, bonuses, or foreign business opportunities for waste handling facilities. 
Although the number and magnitude of environmental programs in China are growing, enforcement of environmental standards and regulations is still limited. In general, compliance with environmental regulations is most often accomplished by large new facilities, since abatement equipment is usually incorporated in the overall design of these plants. For most small-scale and rural facilities, however, compliance with existing regulations is lacking. Because of the large number of small facilities in China, the enforcement of regulations for such facilities and the monitoring of their compliance must be strengthened if the quality of soil systems is to be improved in this country. Higher taxes and fees on wastes produced by industries and increases in fines for noncompliance could be imposed to force small facilities to reduce the amount of waste produced. Price reforms for raw materials and retention of profits could also be used to provide industry with a greater incentive to produce less waste. Also, a shift in emphasis away from production quotas and the internalizing of environmental externalities would help reduce the quantity of waste produced by these facilities. The encouragement of recycling activities and provision of markets for recycled goods would provide additional incentives for waste minimization.

A number of technologies are available for treating solid wastes that are generated. The most effective technology for a given waste depends on the nature and extent of the waste to be treated, characteristics of the waste site, and level of cleanup required. Costs of these technologies can range from $\$ 10$ to $\$ 660 / \mathrm{m}^{3}$ for soil treatment (such as soil vapor extraction, bioremediation, stabilization, and capping) and from $\$ 6$ to $\$ 1,100 / t$ for excavation, incineration, and thermal desorption strategies.

The U.S. experience has shown the strength and effectiveness of well-organized citizen groups in contributing to the enhancement of the quality of all components of the environment, including the air, water, and soil systems. Although local Chinese EPBs are receptive to citizen complaints, the Chinese government is reluctant to allow the formation of independent environmental groups. If such environmental groups were to be allowed to operate in China, they could actually ease the government's enforcement burden, because they could pressure violators to comply with existing laws and could serve as watchdogs for monitoring compliance with such regulations. 


\section{REFERENCES}

Baldwin, A.L., et al., 1995, "Is Selective Catalytic Reduction an Attractive Option for $\mathrm{NO}_{\mathrm{x}}$ Control in Coal-Fired Power Plants?", paper presented at the Economic and Environmental Aspects of Coal Utilization VI Conference, Santa Barbara, Calif., Jan. 29-Feb. 2.

Bhattacharya, S.K., 1992, "How to Engineer Biological Processes That Neutralize Hazardous Wastes," Remediation 2:199-209.

Bhatti, N., et al., 1992, “Acid Rain in Asia," Environmental Management 16:541-562.

Bhatti, N., et al., 1994, Coal Use in the People's Republic of China, Volume 1: Environmental Impacts, ANL/DIS/TM-18, Argonne National Laboratory, Argonne, Ill., Nov.

BNA, 1991, U.S. Environmental Laws, 1991 Ed., W.E. McClain (editor), Bureau of National Affairs, Inc., Washington, D.C.

Bond, R.G., et al. (editors), 1974, Handbook of Environmental Control, Volume IV: Wastewater: Treatment and Disposal, CRC Press, Cleveland, Ohio.

Corbitt, R.A., 1990, Standard Handbook of Environmental Engineering, McGraw-Hill, Inc., New York, N.Y.

DOE, 1994, Clean Coal Technology, The New Coal Era, DOE/FE-0217P, U.S. Department of Energy, Washington, D.C.

Dworsky, L.B., 1971, Water and Air Pollution: Conservation in the United States, Chelsea House Publishers, New York, N.Y.

EPA, 1985, Handbook, Remedial Action at Waste Disposal Sites (Revised), EPA/625/6-85/006, U.S. Environmental Protection Agency, Oct.

EPA, 1991, The Superfund Innovative Technology Evaluation Program: Technology Profiles, 4th Ed., EPA 540/5-91-008, U.S. Environmental Protection Agency.

EPA, 1992, Vendor Information System for Innovative Treatment Technologies (VISITT), Version 1.0, EPA/542/R-92/001, U.S. Environmental Protection Agency, June.

EPA, 1994, Remediation Technologies Screening Matrix and Reference Guide, EPA/542/B-94/013, U.S. Environmental Protection Agency, Oct. 
Fengqi, Z., 1992, "Integrated Energy-Environment Planning," presented at the U.S.-China Conference on Energy-Environment and Market Mechanism, San Francisco, Calif., Oct. 21-Nov. 2.

Florig, H.K., 1993, "The Benefits of Air Pollution Reduction in China," presented at the Fifth International Summer Symposium on Science and World Affairs, Massachusetts Institute of Technology, Cambridge, Mass., July 22-30.

Florig, K., et al., 1995, "China Strives to Make the Polluter Pay," Environmental Science and Technology 29:268-273.

Fullen, M., and D. Mitchell, 1994, "Desertification and Reclamation in North-Central China," Ambio 23:131-135.

Government Institutes, Inc., 1993, Environmental Law Handbook, 12th Ed., Rockville, Md.

Harte, J., 1983, "An Investigation of Acid Precipitation in Qinghai Province, China," Atmospheric Environment 17:403-408.

ICAC, 1994a, White Paper - Scrubber Myths and Realities, Institute of Clean Air Companies, Washington, D.C., Oct.

ICAC, 1994b, White Paper - Selective Catalytic Reduction (SCR) Controls to Abate NO Emissions, Institute of Clean Air Companies, Washington, D.C., Oct.

ICAC, 1994c, White Paper - Selective Non-Catalytic Reduction (SNCR) for Controlling $\mathrm{NO}_{x}$ Emissions, Institute of Clean Air Companies, Washington, D.C., July.

IEA Coal Research, 1993, Sulphur and Coal, IEACR/57, International Energy Agency, London, England, March.

IEA Coal Research, 1995, Air Pollution Control Costs for Coal-Fired Power Stations, IEAPER/17, International Energy Agency, London, England, Jan.

IT Corporation, 1991, Assessment of Selected Technologies for Remediation of Manufactured Gas Plant Sites, EPRI-GS-7554, Electric Power Research Institute, Palo Alto, Calif.

Jinfa, L., 1994, “China Combats Desertification,” Our Planet 6:25-26.

Li, B., and C.J. Johnson, 1994, China's Booming Electricity Sector - The Opportunities and Challenges, report, East-West Center, Honolulu, Hawaii, Feb. 18. 
Lu, Y., 1993, Fueling One Billion, The Washington Institute Press, Washington, D.C.

Miller, G.T, Jr., 1982, Living in the Environment, Wadsworth Publishing Co., Belmont, Calif.

Ministry of Energy, 1992, Energy in China 1992, Beijing, People's Republic of China.

NAPAP, 1990, Technologies and Other Measures for Controlling Emissions: Performance, Costs and Applicability, State of Science and Technology Report 25, National Acid Precipitation Assessment Program, Washington, D.C., Dec.

Noyes, R., 1991, Handbook of Pollution Control Processes, Noyes Publications, Park Ridge, N.J.

Palmer, S.A.K., et al., 1988, Metal/Cyanide Containing Wastes Treatment Technologies, Noyes Data Corporation, Park Ridge, N.J.

PNL, 1992, Remedial Action Assessment System (RAAS), Technology Information System - Version 1.2, Pacific Northwest Laboratory, Hanford, Wash.

Robinson, E., 1977, "Effects of the Physical Properties of the Atmosphere," pp. 1-64 in Air Pollution Volume II: The Effects of Air Pollution, A.C. Stern (editor), Academic Press, New York, N.Y.

Rose, A., et al., 1994, Coal Use in the People's Republic of China, Volume 2: The Economic Effects of Constraining Coal Utilization, ANL/DIS/TM-22, Argonne National Laboratory, Argonne, Ill., Dec.

Rosengrant, L., and L. Lopez, 1991, Treatment Technology Background Document, EPA/530-SW90-059Z, PB91-160556., U.S. Environmental Protection Agency.

Schroeder, J.D., et al., 1992, In-Situ Air Stripping: Cost Effectiveness of a Remediation Technology Field Tested at the Savannah River Integrated Demonstration Site, LA-UR-92-1927, Los Alamos National Laboratory, Los Alamos, N.M., June.

Shanley, A., 1995, "China Sets a New Agenda," Chemical Engineering, pp. 30-31, 35, Apr.

Shoat, D.G., et al., 1993, "The Potential of Pulse-Jet Baghouses for Utility Boilers, Part 3: Comparative Economics of Pulse-Jet Baghouse, Precipitators and Reverse-Gas Baghouses," Journal of the Air and Waste Management Association 43:120-128, Jan. 
Siddiqi, T.A., et al., 1994, National Response Strategy for Global Climate Change: People's Republic of China, final report of the Technical Assistance Project (TA 1690-PRC), prepared by the East-West Center, Honolulu, Hawaii, Argonne National Laboratory, Argonne, Ill., and Tsinghua University, Beijing, China, for the Office of Environment, Asian Development Bank, Manila, Philippines, Sept.

Sinton, J.E. (editor), 1992, China Energy Datebook, Lawrence Berkeley Laboratory, Berkeley, Calif.

Tchobanoglous, G., and E. Schroeder, 1987, Water Quality, Addison-Wesley Publishing Co., Reading, Mass.

Travis, P.S., 1991, Environmental Issues in China, LA-12153-MS, Los Alamos National Laboratory, Los Alamos, N.M.

UNEP (United Nations Environmental Programme), 1993, Environmental Data Book - 1993-1994, Blackwell Publishers, Oxford, England.

UNEP/WHO (United Nations Environmental Programme/World Health Organization), 1994, “Air Pollution in the World's Megacities," Environment 36:4-13, 25-37.

Van der Leeden, F., et al., 1990, The Water Encyclopedia, 2nd Ed., Lewis Publishers, Chelsea, Mich.

Weilert, C.V., and P.N. Dyer, 1995, "Trends in FGD System Operating Cost," in Proceedings of the American Power Conference, Chicago, Ill., Apr. 18-20.

WER, 1993, “Asia Region Seen as Key Market for Environmental Technologies," World Environment Report, p. 194, Dec. 8.

WER, 1994a, “China Briefs," World Environment Report, p. 135, July 20.

WER, 1994b, “China Briefs," World Environment Report, p. 167, Sept. 14.

WER, 1995a, "China Briefs,” World Environment Report, p. 16, Jan. 18.

WER, 1995b, "Sustainable Development," World Environment Report, p. 180, Oct. 11.

WHO/UNEP (World Health Organization/United Nations Environmental Programme), 1992, Urban Air Pollution in the Megacities of the World, Blackwell Publishers, Oxford, England.

Wilson, N.C., 1993, “China Faces Hard Energy Choices," Climate Alert 6(3):1, 4-7. 
Woodyard, P.T., 1991, "Considerations in the Selection of Environmental Biotechnology as Viable in Field-Scale Waste Treatment Applications," in Environmental Biotechnology for Waste Treatment, G.S. Sayler et al. (editors), Plenum Press, New York, N.Y.

WRI (World Resources Institute), 1992, The 1992 Environmental Almanac, Houghton Mifflin Company, Boston, Mass.

WuDunn, S., 1993, "Chinese Suffer from Rising Pollution as Byproduct of the Industrial Boom," New York Times, Feb. 28.

Xu, X., 1995, personal communication from Xu (Tsinghua University, Beijing, China) to L. Poch (Argonne National Laboratory, Argonne, Ill.), Aug. 28.

Zhao, D., and B. Sun, 1981, "Air Pollution and Acid Rain in China," Ambio 15:2-5.

Zhao, D., and J. Xiong, 1988, "Acidification in Southwestern China," pp. 317-346 in Acidification in Tropical Countries, SCOPE 36, H. Rodhe and R. Herrera (editors), John Wiley and Sons, Chichester, England. 
APPENDIX A:

U.S. WATER QUALITY CRITERIA AND WORLD HEALTH ORGANIZATION GUIDELINES FOR DRINKING WATER QUALITY 
TABLE A.1 U.S. Water Quality Criteria ${ }^{a}$ (1972-1994) and World Health Organization Guidelines for Drinking Water Quality (1984) ( $\mu \mathrm{g} / \mathrm{L}$ except as noted otherwise)

\begin{tabular}{|c|c|c|c|c|c|c|}
\hline \multirow[b]{2}{*}{ Chemical } & \multirow{2}{*}{$\begin{array}{c}\text { WHO } \\
\text { Guidelines }\end{array}$} & \multicolumn{5}{|c|}{ Maximum Contaminant Levels ${ }^{\mathrm{b}}$} \\
\hline & & 1972 & 1976 & 1988 & 1991 & 1994 \\
\hline Acrylamide & $-c$ & - & - & - & $\operatorname{TT}^{d}$ & TT \\
\hline Adipate (diethylhexyl) & - & - & - & - & 500 & 400 \\
\hline Alachlor & - & - & - & - & 2 & 2 \\
\hline Aldicarb & - & - & - & - & 1 & 7 \\
\hline Aldicarb sulfone & - & - & - & - & 3 & 7 \\
\hline Aldicarb sulfoxide & - & - & - & - & 3 & 7 \\
\hline Ammonia & - & 500 & - & - & - & - \\
\hline Antimony & - & - & - & - & 5 & 6 \\
\hline Arsenic & 50 & 100 & 50 & 50 & 50 & 50 \\
\hline Asbestos & - & - & - & - & $\begin{array}{r}7 \times 10^{6} \\
\text { fibers } / \mathrm{L}^{\mathrm{f}}\end{array}$ & $\begin{array}{l}7 \times 10^{6} \\
\text { fibers } / \mathrm{L}\end{array}$ \\
\hline Atrazine & - & - & - & - & 3 & 3 \\
\hline Barium & - & 1,000 & 1,000 & 1,000 & 2,000 & 2,000 \\
\hline Benz(a)anthracine & - & - & - & - & 0.1 & 0.1 \\
\hline Benzene & 10 & - & - & 5 & 5 & 5 \\
\hline Benz(a)pyrene & - & - & - & - & 0.2 & 0.2 \\
\hline Benzo(b)fluoranthene & - & - & - & - & 0.2 & 0.2 \\
\hline Benzo(k)fluoranthene & - & - & - & - & 0.2 & 0.2 \\
\hline Beryllium & - & - & - & - & 1 & - \\
\hline Bromate & - & - & - & - & - & 10 \\
\hline Bromodichloromethane & - & - & - & 100 & 100 & 100 \\
\hline Bromoform & - & - & - & 100 & 100 & 100 \\
\hline Butyl benzyl phthalate (PAE) & - & - & - & - & 100 & 100 \\
\hline Cadmium & 5 & 10 & 10 & 10 & 5 & 5 \\
\hline Carbofuran & - & - & - & - & 40 & 40 \\
\hline Carbon tetrachloride & 3 & - & - & 5 & 5 & 5 \\
\hline Chloral hydrate & - & - & - & - & - & 60 \\
\hline Chlordane & 0.3 & 3 & - & - & 2 & 2 \\
\hline Chlorine & - & - & - & - & - & 4,000 \\
\hline Chlorine dioxide & - & - & - & - & - & 800 \\
\hline Chlorite & - & - & - & - & - & 1,000 \\
\hline o-, m-Dichlorobenzene & - & - & - & 10 & 600 & 600 \\
\hline p-Dichlorobenzene & - & - & - & 75 & 75 & 75 \\
\hline Monochlorobenzene & - & - & - & 10 & 100 & 100 \\
\hline
\end{tabular}


TABLE A.1 (Cont.)

\begin{tabular}{|c|c|c|c|c|c|c|}
\hline \multirow[b]{2}{*}{ Chemical } & \multirow{2}{*}{$\begin{array}{l}\text { WHO } \\
\text { Guidelines }\end{array}$} & \multicolumn{5}{|c|}{ Maximum Contaminant Levels ${ }^{b}$} \\
\hline & & 1972 & 1976 & 1988 & 1991 & 1994 \\
\hline \multicolumn{7}{|l|}{ Chlorinated ethanes } \\
\hline 1,2-Dichloroethane & 10 & - & - & 5 & 5 & 5 \\
\hline 1,1,1-Trichloroethane & - & - & - & 200 & 200 & 200 \\
\hline 1,1,2-Trichloroethane & - & - & - & - & 5 & 5 \\
\hline \multicolumn{7}{|l|}{ Clorinated phenols } \\
\hline Pentachlorophenol & 10 & - & - & 30 & 1 & 1 \\
\hline $\begin{array}{l}\text { 2,4-Dichlorophenoxyacetic } \\
\text { acid }\end{array}$ & 100 & 20 & 20 & 100 & 70 & 70 \\
\hline Chlorodibromomethane & - & - & - & - & 100 & 100 \\
\hline Chloroform & 30 & - & - & 100 & 100 & 100 \\
\hline Chromium (total) & 50 & 50 & 50 & 50 & 100 & 100 \\
\hline Chrysene & - & - & - & - & 0.2 & 0.2 \\
\hline Copper & 1,000 & 1,000 & 1,000 & 1,000 & 1,300 & TT \\
\hline Cyanide & 0.1 & - & - & - & 200 & 200 \\
\hline $\mathrm{DDT}^{e}$ & 1.0 & 50 & - & - & - & - \\
\hline Dalapon & - & - & - & - & 200 & 200 \\
\hline Di(2-ethylhexyl)adipate & - & - & - & - & - & 400 \\
\hline Dibenz(a,h)anthracene & - & - & - & - & 0.3 & 0.3 \\
\hline Dibromochloropropane (DBCP) & - & - & - & - & 0.2 & 0.2 \\
\hline Dichloroacetic acid & - & - & - & - & .- & 60 \\
\hline o-Dichlorobenzene & - & - & - & - & 600 & 600 \\
\hline m-Dichlorobenzene & - & - & - & - & 600 & 600 \\
\hline p-Dichlorobenzene & - & - & - & - & 75 & 75 \\
\hline 1,1-Dichloroethylene & 0.3 & - & - & 7 & 7 & 7 \\
\hline 1,2-Dichloroethylene (cis) & - & - & - & - & 70 & 70 \\
\hline 1,2-Dichloroethylène (trans) & - & - & - & - & 100 & 100 \\
\hline Dichloromethane & - & - & - & - & 5 & 5 \\
\hline 1,2-Dichloropropane & - & - & - & 5 & 5 & 5 \\
\hline Dieldrin & 0.03 & 1 & - & - & - & - \\
\hline Endothall & - & - & - & 0.2 & 100 & 100 \\
\hline Endrin & - & 0.5 & 0.5 & 0.2 & 2 & 2 \\
\hline Epichlorohydrin & - & - & - & - & $\mathrm{TT}$ & $\mathrm{TT}$ \\
\hline Ethylbenzene & - & - & - & 30 & 700 & 700 \\
\hline Ethylene dibromide (EDB) & - & - & - & - & 0.05 & 0.05 \\
\hline Fluorene & - & - & - & - & 0.2 & - \\
\hline Glyphosate & - & - & - & - & 700 & 700 \\
\hline Heptachlor & 0.1 & 0.1 & 0.1 & - & 0.4 & 0.4 \\
\hline
\end{tabular}


TABLE A.1 (Cont.)

\begin{tabular}{|c|c|c|c|c|c|c|}
\hline \multirow[b]{2}{*}{ Chemical } & \multirow{2}{*}{$\begin{array}{l}\text { WHO } \\
\text { Guidelines }\end{array}$} & \multicolumn{5}{|c|}{ Maximum Contaminant Levels ${ }^{\mathfrak{b}}$} \\
\hline & & 1972 & 1976 & 1988 & 1991 & 1994 \\
\hline Heptachlor epoxide & 0.1 & 0.1 & 0.1 & - & 0.2 & 0.2 \\
\hline $\begin{array}{l}\gamma \text {-Hexachlorocyclohexane } \\
\text { (lindane) }\end{array}$ & 3 & 5 & 4 & 4 & 0.2 & 0.2 \\
\hline Hexachlorocyclopentadiene & - & - & - & - & 50 & 50 \\
\hline Iron & - & 300 & 300 & 300 & - & - \\
\hline Lead (at tap) & 50 & 50 & 50 & 50 & TT & TT \\
\hline Manganese & - & 50 & 50 & 50 & - & - \\
\hline Mercury & 1 & 2 & 2 & 2 & 2 & 2 \\
\hline Methoxychlor & 30 & 1,000 & 100 & 100 & 40 & 40 \\
\hline Nickel (total) & - & - & - & - & 100 & 100 \\
\hline Nitrate, as $\mathrm{N}$ & 10,000 & 10,000 & 10,000 & 10,000 & 10,000 & 1,000 \\
\hline Nitrite, as $\mathrm{N}$ & - & 1,000 & - & - & 1,000 & 1,000 \\
\hline Picloram & - & - & - & - & 500 & 500 \\
\hline Diethylhexylphthalate (PAE) & - & - & - & - & 4 & 6 \\
\hline $\begin{array}{l}\text { Polychlorinated biphenyls } \\
\text { (PCBs) }\end{array}$ & - & - & - & - & 0.5 & 0.5 \\
\hline \multicolumn{7}{|l|}{ Radionuclides } \\
\hline $\begin{array}{l}\text { Beta particle and photon } \\
\text { activity }\end{array}$ & - & - & - & - & $4 \mathrm{mrem}$ & $4 \mathrm{mrem}$ \\
\hline Gross alpha particle activity & - & $\therefore$ & - & $15 \mathrm{pCi} / \mathrm{L}$ & $15 \mathrm{pCi} / \mathrm{L}$ & $15 \mathrm{pCi} / \mathrm{L}$ \\
\hline Radium 226 & - & - & - & $5 \mathrm{pCi} / \mathrm{L}$ & $5 \mathrm{pCi} / \mathrm{L}$ & $20 \mathrm{pCi} / \mathrm{L}$ \\
\hline Radium 228 & - & - & - & $5 \mathrm{pCi} / \mathrm{L}$ & $5 \mathrm{pCi} / \mathrm{L}$ & $20 \mathrm{pCi} / \mathrm{L}$ \\
\hline Radon & - & - & - & - & - & $300 \mathrm{pCi} / \mathrm{L}$ \\
\hline Uranium & - & - & - & - & - & 20 \\
\hline Selenium & 10 & 10 & 10 & 10 & 50 & 50 \\
\hline Silver & - & - & 50 & 90 & - & - \\
\hline Simazine & - & - & - & - & 1 & 4 \\
\hline Styrene & - & - & - & 10 & 100 & 100 \\
\hline 2,4,5-TP (Silvex) & - & 30 & 10 & - & 50 & 50 \\
\hline 2,3,7,8-TCDD (dioxin) & - & - & - & - & $5 \times 10^{-5}$ & $3 \times 10^{-5}$ \\
\hline Tetrachloroethylene & 10 & - & - & - & 5 & 5 \\
\hline Thallium & - & - & - & - & 2 & 2 \\
\hline Toluene & - & - & - & 40 & 1,000 & 1,000 \\
\hline Toxaphene & - & 5 & 5 & 5 & 5 & 3 \\
\hline 1,2,4-Trichlorobenzene & - & - & - & . - & 9 & 70 \\
\hline 1,1,1-Trichloroethane & - & - & - & 200 & 200 & 200 \\
\hline Trichloroethylene & 30 & - & - & 5 & 5 & 5 \\
\hline
\end{tabular}




\begin{tabular}{|c|c|c|c|c|c|c|}
\hline \multirow[b]{2}{*}{ Chemical } & \multirow{2}{*}{$\begin{array}{l}\text { WHO } \\
\text { Guidelines }\end{array}$} & \multicolumn{5}{|c|}{ Maximum Contaminant Levels ${ }^{b}$} \\
\hline & & 1972 & 1976 & 1988 & 1991 & 1994 \\
\hline Vinyl chloride & - & - & - & 2 & 2 & 2 \\
\hline Xylene & - & - & - & 20 & 10,000 & 10,000 \\
\hline Zinc & - & 5,000 & 5,000 & 5,000 & - & - \\
\hline
\end{tabular}

a These are selected standards for common contaminants in surface water.

b These standards for maximum contaminant levels are part of the national primary drinking water regulations (40 CFR 141).

c A hyphen denotes that a standard or criterion has not been adopted.

d TT denotes a level best achievable by treatment technique.

e Use of DDT in the United States has been prohibited since 1973.

f Fibers per liter (fibers longer than $10 \mu \mathrm{m}$ ).

Sources:

U.S. Environmental Protection Agency, 1973, Water Quality Criteria 1972, EPA-R3-73-33.

U.S. Environmental Protection Agency, 1976, Quality Criteria for Water, EPA-440/9-76-023.

U.S. Environmental Protection Agency, 1988, Guidance on Remedial Actions for Contaminated Ground Water at Superfund Sites, EPA/540/G-88/003, Office of Emergency Response, Dec.

U.S. Environmental Protection Agency, 1991, Drinking Water Regulations and Health Advisories, Office of Water, April.

U.S. Environmental Protection Agency, 1994, Drinking Water Regulation and Health Advisories, Office of Water, Nov.

World Health Organization, 1984, Guidelines for Drinking-Water Quality, Vol. 1, Recommendations; also U.S. Environmental Protection Agency, 1988. 


\section{APPENDIX B:}

SURFACE WATER QUALITY LIMITS FOR THE PUBLIC WATER SUPPLY IN THE UNITED STATES 
TABLE B.1 Surface Water Quality Limits

for the Public Water Supply in the

United States

\begin{tabular}{lc}
\hline \multicolumn{1}{c}{ Chemical } & $\begin{array}{c}\text { Concentration } \\
\text { (mg/L) }\end{array}$ \\
\hline Inorganic & \\
Arsenic & 0.05 \\
Barium & 1.00 \\
Cadmium & 0.01 \\
Chromium & 0.05 \\
Copper & 1.00 \\
Iron (soluble) & 0.30 \\
Lead & 0.05 \\
Manganese & 0.05 \\
Nitrate + Nitrite (as $\mathrm{N}$ ) & 10.00 \\
Selenium & 0.01 \\
Zinc & 5.00 \\
& \\
Organic & \\
Endrin & 0.0002 \\
Lindane & 0.004 \\
Methoxychlor & 0.10 \\
Toxaphene & 0.005 \\
2,4-D & 0.10 \\
2,4,5-TP & 0.01 \\
Phenols & 0.001 \\
pH (units) & $5.0-9.0$ \\
\hline & \\
& \\
\hline &
\end{tabular}

Source: U.S. Environmental Protection Agency, 1976, Quality Criteria for Water, EPA-440/9-76-023. 
